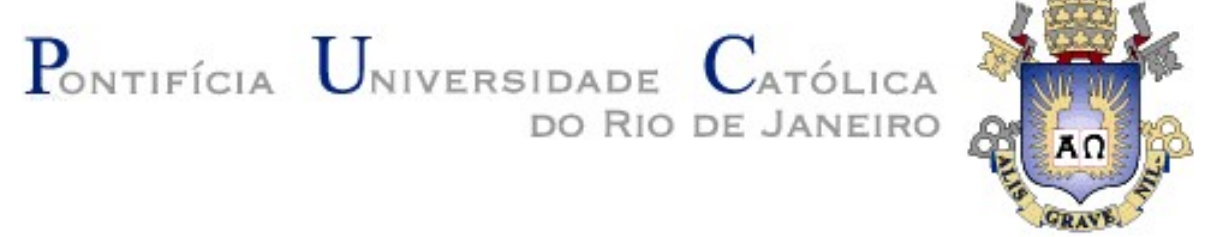

Maria Priscilla Vieira Coelho Familiar

For the conquest of an inheritance:

The Sistine as Bild in the light of Heidegger

Tese de Doutorado

Thesis presented to the Programa de Pós-graduação em Filosofia of PUC-Rio in partial fulfillment of the requirements for the degree of Doutor em Filosofia.

Advisor: Prof. Luiz Camillo Osório

Rio de Janeiro

November 2017 


\section{Maria Priscilla Vieira Coelho Familiar}

\section{For the conquest of an inheritance:}

the Sistine as Bild in the light of Heidegger

Thesis presented to the Programa de Pós-Graduação em Filosofia of PUC-Rio in partial fulfillment of the requirements for the degree of Doutor em Filosofia. Approved by the undersigned Examination Committee.

Prof. Luiz Camillo Osório

Advisor

Departamento de Filosofia - PUC-Rio

Profa. Ligia Saramago

Departamento de Filosofia - PUC-Rio

Prof. Remo Mannarino Filho

Departamento de Filosofia - PUC-Rio

Profa. Marcia Cavalcante Schuback Departamento de Filosofia - Södertörn University

Prof. Fernando Fragozo Departamento de Filosofia - UFRJ

Profa. Monah Winograd

Vice Dean of Graduate Studies

Centro de Teologia e Ciências Humanas - PUC-Rio 
All rights reserved.

\section{Maria Priscilla Vieira Coelho Familiar}

The author obtained a Master Degree in Philosophy from Pontifícia Universidade Católica do Rio de Janeiro in 2012. She graduated in Philosophy at PUC-Rio in 2009 and spent a semester as an exchange student at Södertörn Högskola (Stockholm). She obtained additional studies on Cultura clássica greco-latina from PUC-Rio. She was editor of two issues of the journal Analógos. She was also a member of the committee that developed its site: www.analogos.fil.puc-rio.br. She presented papers in several seminars and was a member of many organizing committees of conferences in the Philosophy field. She received grants from Capes, CNPq FAPERJ and SIDA.

Ficha Catalográfica

Familiar, Maria Priscilla Vieira Coelho

For the conquest of an inheritance : the Sistine as Bild in the light of Heidegger / Maria Priscilla Vieira Coelho Familiar ; advisor: Luiz Camillo Osório. - 2017.

$154 \mathrm{f}$. : il. color. ; $30 \mathrm{~cm}$

Tese (doutorado)-Pontifícia Universidade Católica do Rio de Janeiro, Departamento de Filosofia, 2017.

Inclui bibliografia

1. Filosofia - Teses. 2. Antlitz. 3. Ereignis. 4. Pertencimento. 5. Altar. 6. Janela. I. Osório, Luiz Camillo. II. Pontifícia Universidade Católica do Rio de Janeiro. Departamento de Filosofia. III. Título. 
It has been said... that there is time to plant and time to harvest, that we cannot buy time, that it is not possible to rush or delay not even an instant. Indeed, what we do can is, nurturing with intensity each instant, seed it. The ripening, flourishing, and bearing of fruit require an own dimension. I would like to dedicate this work to all those who somehow have contributed so that I could have such precious good. 


\section{Acknowledgements}

I would like to acknowledge my debts...

To PUC-Rio, to CAPES and to FAPERJ for the grants without which this work wouldn't be possible. For the important extensions that were provided.

To my advisor, Luiz Camillo Osório, for his readiness to discuss the project developments and the trust he has relied on me. For the lightness he has shared, which made the whole process of writing the dissertation less painful. For having inspired on me a more patient way of waiting unpredictable unfoldings of life.

To Professor John Sallis, for having accepted me and for his availability to arrange our meetings. For all the good memories I have of Boston College.

To Luiz Carlos Pereira, for keep following my path and instructing me. For all the tireless care he has dedicated to me. For the advice to go to the U.S. For the generous support to bring Marcia Cavalcante to my Ph.D. board.

To Marcia Cavalcante, for the encouragements and the exchanges. For her interest and engagement in my research and my path. For introducing me to the Kluge. For all her translations of Heidegger's texts, which were a blessed help. For the tips on Boston.

To Paulo Cesar Duque-Estrada, for the years of research together, for the encouragements concerning Boston College and for welcoming me in his classes. For the support and peace he has provided me to finish writing my dissertation.

To Ligia Saramago, for all her advises and all the care she has dedicated to me and my research; for introducing me to Heidegger's text on the Sistine Madonna. 
To Nancy Fedrow, for being so kind and gentle to me. For all her prayers.

To Gilvan Fogel, for having tuned my listening.

To Professor Jean-Luc Solère, for his inspiring classes and all the valuable discussions we had.

To Déborah Danowski, for accompanying my studies on Leibniz.

To Paulo Fernando Andrade, for the support and availability.

To Edna Sampaio, Daniel Teixeira and Diná Santos, for the institutional support.

To Maria Inês Anachoreta and Remo Mannarino Filho for all the dialogues that have helped me to take larger steps along my research.

To Vânia Kampff, for all the light and care.

To Pedro Carné, for having given me twice the keys of heaven, welcoming me both at PUC and in Boston.

To Andrea Lohmann and the cheerful Lucas, for their welcoming generosity.

To Matthew Ray, John Bagby, Sean Driscoll, Melissa Fitzpatrick, Stephanie Rumpza, Nathaniel Peters, Jacquelyn Liberty, Acylene Ferreira, Roberto Wu, Klaus Raupp, Vicente Muñoz-Reja, Mike Providenza and Danielle Heitmann for having brightened my days in Boston.

To my friends: Antônio Aisengart, Maria Eduarda Mendonça, Julia Almeida, José Antônio Motta, Fernanda Alvarenga, Julia Spritzer, Antônio Campinho and Ianick Diuana, for their friendship. 
To my friends from Philosophy: André Pontes, Bernardo Boelsums, Bianca Tossato, Daniel Cardoso, Fernanda Lobo, Gustavo Batista, Marcos Lesbaupin, Thiago Faria e Victor Melo.

To Christina Von Rabenau, for the welcoming Caspar David Friedrich tour and the warm reception in Greifswald.

To Elisa Neuschulz, for having shared the enthusiasm to see Raphael's Sistine Madonna and willed to join me to Dresden. For her sweet visit to Boston and her availability to study the German texts with me.

To Daniel Leite, for helping me with the German readings and translations. For having found the painting I searched for so long.

To German Lourenço Mejia, for having offered me his hand and having strengthened my steps.

To Paulo Anderson, for the peace his uplifted spirit has brought me.

To my father, for his concern with the thesis developments.

To Emmanuel Barreto, for the everlasting memories.

To my three Marys, my sister, my mother and my grandmother for guiding me with their shine.

To my aunt, Fernanda Sabina, for the soul affinity that bond us. 


\section{Abstract}

Coelho, Maria Priscilla; Osório, Luiz Camillo (Advisor). For the conquest of an inheritance: the Sistine as Bild in the light of Heidegger. Rio de Janeiro, 2017. 154p. Tese de Doutorado - Departamento de Filosofia, Pontifícia Universidade Católica do Rio de Janeiro

In the light of Heidegger's remarks in his text On the Sistine Madonna, I intend to defend that the singularity of the Sistine Madonna as a sui generis Bild essencing (Bildwesen) is related to an enowning (Ereignis) that is brought forth in this painting. I will argue that it is possible to trace this enowning through the investigation of Heidegger's specification of his use of the term Bild as meaning Antlitz (countenance), and of his characterization of this Bild as being an AltarBild. According to the philosopher, the bringing into emergence brings into emergence (das Bild bildet) both: a window and a site (Ort). In the first chapter, I will relate the meaning of Antlitz as an Entgegenblick (encountering glance) as arrival to the window character as an outlook (Ausblick) of arrival. The aim is to suggest that what singularizes this Bild is its reference to a disclosure of appropriation (Ereignis) of the mutual belonging of concealment and unconcealment. In the second chapter, I will relate the altar character of the Bild to the bringing into emergence of a site. My purpose is to link the Sistine's belonging to a site to a mutual belonging of sites, that is: a belonging together of the altar and the church. Supposing that they are both related to the memory of the sacred, they could be related to thinking as the safeguard of the sacred. According to Heidegger, "the thinking is the thinking of being". This means that it belongs to being and that it listens to being. It is an enowning (Ereignis).

\section{Keywords}

Antlitz; Ereignis; belonging; altar; window. 


\section{Resumo}

Coelho, Maria Priscilla; Osório, Luiz Camillo. Pela conquista de uma herança: a Madona Sistina como Bild à luz de Heidegger. Rio de Janeiro, 2017. 154p. Tese de Doutorado - Departamento de Filosofia, Pontifícia Universidade Católica do Rio de Janeiro.

À luz das considerações de Heidegger em seu texto Sobre a Madona Sistina, pretendo defender que a singularidade da Madona Sistina como um sui generis essenciar do Bild está relacionada a um transparecer apropriativo (Ereignis) que emerge nesta pintura. Vou argumentar que é possível rastrear este transparecer apropriativo através da investigação da especificação que Heidegger faz de seu uso do termo Bild como significando Antlitz (semblante) e de sua caracterização deste Bild como sendo um Altar-Bild. De acordo com o filósofo, o trazer à emergência traz à emergência (das Bild bildet) ambos: uma janela e um sítio (Ort). No primeiro capítulo, vou relacionar o sentido de Antlitz como um Entgegenblick (um olhar voltado a um encontro) enquanto chegada ao caráter de janela enquanto um olhar para fora (Ausblick) na direção daquilo que chega. $\mathrm{O}$ objetivo é sugerir que aquilo que singulariza este Bild é sua referência a um transparecer apropriativo do mútuo pertencimento de velar e desvelar. No segundo capítulo, vou relacionar o caráter de altar do Bild ao trazer à emergência de um sítio. Meu propósito é associar o pertencimento da Madona Sistina a um sítio a um mútuo pertencimento de sítios, a saber: um mútuo pertencimento do altar e da igreja. Supondo que ambos estão relacionados à memória do sagrado, eles poderiam ser relacionados ao pensamento enquanto a salvaguarda do sagrado. Segundo Heidegger, “o pensamento é pensamento do Ser”. Isso significa que ele pertence ao Ser e que ele ausculta o Ser. Ele é um transparecer apropriativo (Ereignis).

\section{Palavras-chave}

Antlitz; Ereignis; pertencimento; altar; janela. 


\section{Contents}

1. Introduction 17

2. The Bild as Antlitz 28

3. The Bild as Altar-Bild

4. Final remarks 121

5. Glossary 127

$\begin{array}{ll}\text { 6. References } & 129\end{array}$

7. Appendix 143 


\section{List of figures ${ }^{*}$}

Figure 1 - The Sistine Madonna, Raphael

Figure 2 - An Old Man and a Youth Facing One Another, Da Vinci

Figure 3 - Primordial Caos, Zhu Derun

Figure 4 - The Cathedral, Rodin

Figure 5 - "Weighing of the heart", Book of the Dead, unknown artist 118 


\title{
System of abbreviations
}

\author{
WORKS BY, AND TRANSLATIONS OF, HEIDDEGER
}

The volumes of Heidegger's Gesamtausgabe are indicated by the abbreviation GA followed by the number of the volume. Only the texts of each volume that were related to this dissertation were listed below. The way each text is referred to in the footnotes is indicated by the words in bold type. This quick reference is based on the translation title. When it is said that the availability is unknown, it is meant translations to the English. The numbers between '[ ]' refer to the numbers on the margin of the GA volume.

GA-Gesamtausgabe

GA 2 - Sein und Zeit (1927)

BT - Being and Time.

GA 5 - Holzwege (1935-1946)

Translated as Off the Beaten Track. There are a few texts of this volume in Poetry, language, thought (PLT), in Early Greek Thinking (EGT) and in The question concerning technology and other essays.

Anax - The Anaximander Fragment: Der Spruch des Anaximander (1946)

AWP - The Age of the World Picture: Die Zeit des Weltbildes. (1938)

OWA - The Origin of the Work of Art: Der Ursprung der Kunstwerkes (1935-36)

The word of Nietzsche: 'God is dead' - Nietzsches Wort 'Gott ist tot' (1943)

What are Poets for? or Why Poets? - Wozu Dichter? (1946) 
GA 7 - Vorträge und Aufsätze (1936-1953)

Translations available in PLT, Basic Writings and Early Greek Thinking.

What is called thinking?: Was heist Denken? (1952) - Unknown availability.

Building Dwelling Thinking: Bauen Wohnen Denken (1951)

The Thing: Das Ding (1951)

“...Poetically Man Dwells...”: “...dichterisch wohnet der Mensch...” (1951)

Logos (Heraclitus, Fragment B 50): Logos (Heraklit, Fragment 50) (1951)

GA 8 - Was heißt denken? (1951-1952)

Translated as What is called thinking?

GA 9 - Wegmarken (1919-1961)

Translated as Pathmarks. Translations also available in Basic Writings.

Postscript to 'What is Metaphysics?': Nachwort zu 'Was ist Metaphysik' (1943)

Letter on 'humaninsm': Brief über den 'Humanismus' (1946)

GA 12- Unterwegs zur Sprache (1950-1959)

Translated as On the Way to Language (OWL). Translations also available in Basic Writings.

Language: Die Sprache. (1950)

Language in the poem: Die Sprache im Gedicht. Eine Erörterung von Georg Trakls Gedicht (1952) 
A Dialogue on language: Aus einem Gesprach von der Sprache. Zwischen einem Japaner und einem Fragenden (1953-1954)

The Nature of Language: Das Wesen der Sprache (1957)

Words: Das Wort (1958)

The Way to Language: Der Weg zur Sprache (1959)

GA 13 - Aus der Erfahrung des Denkens (1910-1976)

On the Sistine Madonna: Über die Sixtine (1955) - Unknown availability Notes from the workshop - Aufzeichnungen aus der Werkstatt (1959) Unknown availability

Language and homeland: Sprache und Heimat (1960) - Unknown availability

Art and Space: Die Kunst und der Raum (1969). Translation available in the Heidegger reader

GA 15 - Seminare (1951-1973)

Translated as Four Seminars and as Heraclitus Seminar.

GA 16 - Reden und andere Zeugnisse eines Lebensweges (1910-1976)

CH - (185.) Verschiedene Positionen - >>Christlichkeit $<<$ und $>>$ Christentum $<<$ (28. Dezember 1945)

MA - (224.) Memorial address: Gelassenheit. Available in Discourse on thinking

Meßkirch's seventh centennial - 700 Jahre Meßkirch (1961). Available in Listening VIII.

GA 40 - Einführung in die Metaphysik. (1935)

IM - Introduction to metaphysics: Einführung in die Metaphysik. (1935) 
GA 55 - Heraklit - 1. Der Anfang des abendländischen Denkens (Heraklit). 1943.

2. Logik. Heraklits Lehre vom Logos. 1944.

Unknown availability.

GA 65 - Beiträge zur Philosophie (Vom Ereignis) (1936-1938)

Translated as Contributions to Philosophy (From Enowing) and Contributions to Philosophy (of the Event).

GA 73 - Zum Ereignis-Denken (1937)

Poverty: Die Armut. In: SCHALOW, F. Heidegger Translation and the task of thinking.

GA 79 - Bremer und Freiburger Vorträge (1949-1957)

Translated as Bremen and Freiburg lectures.

GA 80 - Vörtrage (1915-1967)

The provenance of art and the destination of thought: Die Herkunft der Kunst und die Bestimmung des Denkens (1967). 
Nous nous habituons à penser que tout cela existe nécessairement et est inébranlable.

L'art est une aperception personnelle.

Maurice Merleau-Ponty 


\title{
Introduction
}

\author{
Did you not know, \\ had you not heard? \\ Was it not told you from the beginning? \\ Have you not understood how the earth was founded? \\ He has stretched out the heavens like a cloth, \\ spread them like a tent (...) to live in. ${ }^{1}$
}

Isaiah

In a strange way, this epigraph introduces us to the famous Raphael's Sistine Madonna ${ }^{2}$. Two pieces of green cloth are spread to reveal a dwelling place, a temple of truth, a tent of alétheia. The tent is known to be the prototype of the temple, where the source of all beginning is found. It was once said that Protestants were "in danger of becoming Catholics"3 in face of the confusion that this work caused. The retorting that "There is no danger if Raphael is the priest" has made the scenario an anecdote. The fact that Schlegel, who once described the confusion around the interpretations of this Madonna, became himself a Catholic gives the whole context an even more puzzling brushstroke.

\footnotetext{
${ }^{1}$ Isaiah 40, 21-22. In the portuguese version of the Jerusalem Bible, it says: "ele estende os céus como uma tela, abre-os como uma tenda que sirva de habitação". (My highlights). It is worth noticing that the canvas is made of cloth, what raises the ambiguity.

${ }^{2}$ See figure 1 on next page. It is also called Madonna di San Sisto. It is believed that Pope Julius II has commissioned it for the high altar of the church of San Sisto in Piacenza in 1512. The canvas stayed in the church for 240 years since 1514. In 1754, August III bought it and exhibited the painting in Dresden. After the Second World War, it was taken to Moscow as a war spoil and since 1955 it is again in the Old Masters Picture Gallery in Dresden. A copy by Joseph Nogari that was given by August III is in Piacenza replacing the original one. See BECKER, K. 'Die Sixtinische Madonna': Historische Umstände und künstlerische Wirkung, p. 4, and HENNING, A. Die Sixtinische Madonna: Raffaels Kultbild wird 500. There is also a version that tells that the painting would have been commissioned to adorn the mortuary chapel of Julius II. Since his tomb was not completed by the pope's death in 1513, the Sistine was temporarily set up at the choir chapel of St. Sixtus in St. Peter's. (See EBERLEIN, J. "The curtain in Raphael's Sistine Madonna", p. 65, and BORGES-DUARTE, I. Arte e técnica em Heidegger, p. 59.) According to Grimme, a little after the funeral ceremony the painting was exiled in Piacenza due to restrictions concerning the roman ritual (See LACOUE-LABARTHE, P. La vraie semblance, p. 51-52).

${ }^{3}$ BELTING, H. Likeness and presence, p. 480.

${ }^{4}$ BELTING, H. Likeness and presence, p. 480.
} 


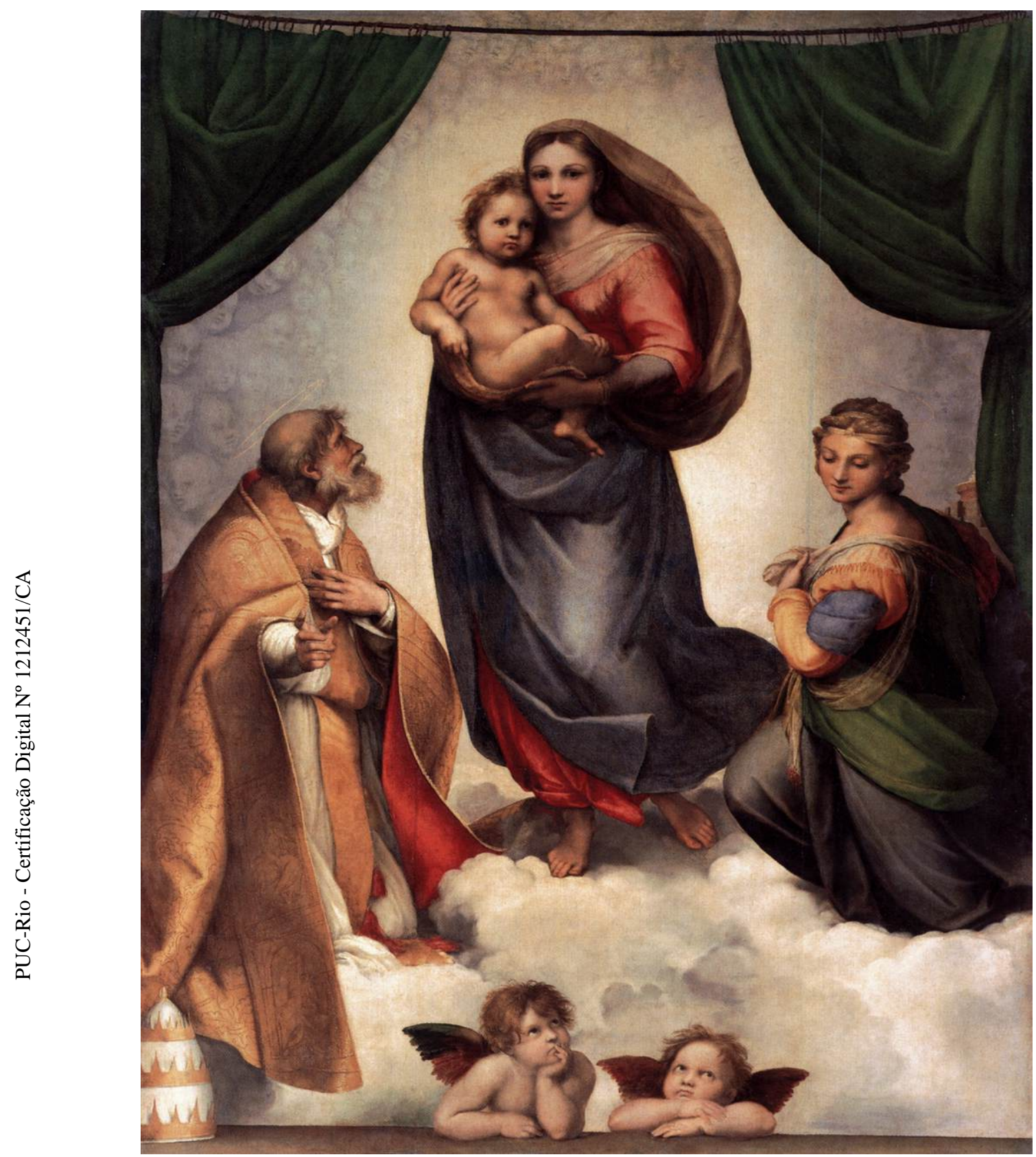

Figure 1

Raphael Sanzio - The Sistine Madonna - 1512/3

Old Masters Picture Gallery, Dresden 
It is known that Heidegger was raised in a Catholic environment and was once a student of theology. He was thus familiar with the Catholic tradition. As philosopher, he became critic of this background. In his book Introduction to metaphysics, he says:

For a more precise account we would have to distinguish here between the synoptic gospels and the gospel of John. But in principle we can say: in the New Testament, from the start, logos does not mean, as in Heraclitus, the Being of beings, the gatheredness of that which contends, but logos means one particular being, namely the Son of $\operatorname{God}^{5}$.

This remark helps us to understand how the Catholic tradition would also fall under his critic of the history of metaphysics, that is: a history that has entified what, for him, must be thought in terms of concealment and unconcealment, that is through the mutual belonging of both.

Nevertheless, in On the Sistine Madonna, Heidegger argues that "the image forms the site of the sheltering unconcealment (of alétheia)" ${ }^{\text {. }}$. How could it be so? How could a Madonna with the Child be related to the truth as alétheia? The surprising character of this account is expressed by Hamacher: "Astonishing as it can seem the emergence of this scene in Heidegger's writings (...), even more astonishing must seem the vocabulary with which he characterizes this scene: nothing less than that of the ontological difference" ${ }^{7}$. Radloff adds, echoing the surprise:

All of this is complicated, evidently, by the fact that the Madonna of Raphael speaks to us of the incarnation of a god, the incarnate God of Christian belief and that Heidegger's confrontation with this heritage is intimately related to his attempt

5 IM [103]. Original: "Für eine genauere Darstellung müßten wir hier wieder unterscheiden wischen den Synoptikern und dem Johannesevangelium. Grundsätzlich aber ist zu sagen: Logos meint im Neuen Testament von vornherein nicht wie bei Heraklit das Sein des Seienden, die Gesammeltheit des Gegenstrebigen, sondern Logos meint ein besonderes Seiendes, nämlich den Sohn Gottes". GA 40 [103], p. 143.

${ }^{6}$ My translation. Original: "bildet das Bild den Ort des entbergenden Bergens (der'Alétheia)". GA 13, p. 121.

${ }^{7}$ My translation of: "Si étonnants que puissant déjà paraître l'émergence de cette scène dans les écrits de Heidegger (...), plus étonnant encore doit paraître le vocabulaire avec lequel il caractérise cette scène: rien moins que celui de la différence ontologique". HAMACHER, W. "Le dépouillement: Expositions de la mère", p. 101. The original is in German. My translation is from the French version. 
to rethink the Greek inception of Western thinking and to open up the possibility of another beginning 8 .

Despite all the astonishment it might raise, Heidegger continues: "The way [my highlight] in which it unconceals itself (its duration in truth) is the shining concealment of the Man-God provenance". The "way" seems to be a key to unfold Heidegger's remark. It would be quite a standard interpretation to link it to a historical way in which truth has disclosed itself, even if it has been entified in the person of Christ. Lacoue-Labarthe synthetizes:

[that] the Sistine Madonna - is $<<$ an image of a-lèthéia $>>$, it does not mean (...) that Christianity (the Catholicism) is the last or ultimate truth of the Greek truth (...); but rather that only the $<<$ logic $>>$ of alèthéia enables to think Christianity in its essence, that is, historically as the $<<$ invention $>>$ of the last divinity, the Virgin Mary, that the West was able to ${ }^{10}$.

Yet, how precisely has Heidegger linked "the shining concealment of the ManGod provenance" to this specific canvas still gives room to investigation.

Let's pay attention, for example, to the beginning of the already quoted extract: "the image $[$ Bild $]$ forms [bildet $]$ the site $[O r t]$ of the sheltering unconcealment (of alétheia)". It says that the image 'images' (bildet das Bild), that the form forms. According to Heidegger, the Sistine Madonna is a sui generis image essencing (ein einzigartiges Bildwesen) ${ }^{11}$. This character is crucial to understand not only what is at stake to him in this canvas, but also the unity of his remarks on this Madonna. The "shining concealment" and the "sheltering unconcealment" address this mutual belonging of the presencing of alétheia. It seems worthy then to dig into what Heidegger calls by Bild in order to clarify the intimacy between the essencing of the image (Bild) and the bringing forth of the mutual belonging of concealment and unconcealment.

\footnotetext{
${ }^{8}$ RADLOFF, B. "Preliminary Notes on Divine Images in the Light of Being-Historical Thinking", p. 146.

${ }^{9}$ My translation. Original: "Die Weise seines Entbergens (seiner Wahr-heit) ist das verhüllende Scheinen der Her-kunft des Gottmenschen”. GA 13, p. 121.

${ }^{10}$ My translation of: "la Madone Sixtine - est une $<<$ figure de l'a-lèthéia $>>$, cela ne signifie pas (...) que le christianisme (le catholicisme) est la vérité grecque (...); mais bien plutôt que seule la $<<$ logique $>>$ de l'alèthéia permet de penser le christianisme en son essence, c'est-à-dire, historialement, comme l' $<<$ invention $>>$ de la dernière divinité, la Vierge Marie, don't l'Occident ait été capable”. LACOUE-LABARTHE, P. “La vraie semblance”, p. 60.

${ }^{11}$ GA 13, p. 119.
} 
How to translate the term 'Bild' seems to be one of the first challenges on this path. In this dissertation title, it was chosen to keep the German word 'Bild' untranslated. This option expresses the discomfort on the mystery (Geheimnis) it involves. It is an effort to maintain it raised as an issue, to insist on the difficulties it brings into emergence. In the body text, the translation to 'image' has been used because it is the most common translation found in similar contexts. It is important to stress, however, that Heidegger himself defended that "the Latin noun imago, in which it is expressed the root imitari" 12 is related to Bild only "in a derivative sense" 13 . He claims that the "originary Bild"14, which he wants to name, is closer to the noun 'icon', derived from the Greek. According to him, icon "has (...) a deeper meaning coming from the verb $\varepsilon 1 \kappa \omega$, that is, to stand back before, to step back before something and then let that before which one stands back arrive - and thus appear" ${ }^{\prime 15}$. It is important to keep in mind then that Bild might be taken as much as image in a derivative sense as in an originary one. This ambiguity has a role. It is inherent to the scenario of forgottenness ${ }^{16}$ of being and the effort to think it. "The unwhole [Unheil - unholy ${ }^{17}$ ], as the unwhole [Unheil unholy], traces for us what is whole [Heile - holy]"18. Despite the unsuitable character of the translation maintaining the Latin root, in the lack of a consensus for a replacement ${ }^{19}$, the word 'image' will keep being used here.

Heidegger starts his On the Sistine Madonna stating that "around this image $[$ Bild $]$ are gathered all still unsolved issues on art and the work of art"20.

\footnotetext{
${ }^{12}$ My translation of: "im lateinischen Namen imago, daraus das Stammwort imitari (...) spricht". GA 13, p. 171.

${ }^{13}$ My translation of: "in einer abgeleiteten Bedeutung". GA 13, p. 171.

${ }^{14}$ Original: "das ursprüngliche Bild". GA 13, p. 171.

${ }^{15}$ My translation of: "hat (...) einen tieferen Sinn, herkommend vom Zeitwort $\varepsilon 1 \kappa \omega$, d. h. zurückweichen vor, zurücktreten vor etwas und so dieses Wovor auf sich zukommen - und damit erscheinen-lassen". GA 13, p. 171.

${ }^{16}$ See INWOOD, p. 72, for a distinction between forgottenness (Vergessenheit) and hiddenness (Verborgenheit).

${ }^{17}$ See translation in PLT, "What are poets for?": "The unholy, as unholy". For the association between unholy and unwhole, see "Why Poets?", p. 221, or "What are poets for?", p. 115, or GA 5 [273].

18 "Why poets?" In: Off the Beaten track, p. 240. Original: "Unheil als Unheil spurt uns das Heile". GA 5 [294], p. 319.

${ }^{19}$ Lacoue-Labarthe has suggested to understand the Bild as originary mimesis or true likeness, for example. The translation to English of Hans Belting's book Bild und Kult presents the title as Likeness and Presence. Nevertheless, throughout the book's translation, the word 'image' is widely employed as the correspondent to Bild.

${ }^{20}$ My translation. Original: "Um dieses Bild versammeln sich alle noch ungelösten Fragen nach der Kunst und dem Kunstwerk”. GA 13, p. 119.
} 
This bring us back to the referred confusion of interpretations around this Madonna. It played a central role in a period of controversy on artistic excellence, since it lends itself to different approaches. The cult image, symbol of presence and memory, starts to give place to the work of art. In contrast with the previous vision of divine conception that inspired the ancient image, the work of art is an image as the representation of an aesthetical vision. The romantic disposition used to "view inspired genius as removed from the labors of reason, so that estimations of a painting's quality depend exclusively on its formal execution, while neglecting meaning" 21 . Since art, in this new context, is a product of human hands based on the artist idea ${ }^{22}$ (of an aesthetic concept), it became subject to criticism and judgement. The role of both, the genius and the critic of art, gained projection, once the work became an artistic expression. The appreciation of technical skills emancipated the work of its worship aspect. Belting elucidates that "The image became an object of reflection as soon as it invited the beholder not to take its subject matter literally but to look for the artistic idea behind the work" ${ }^{23}$. There were then two concepts of image coexisting: the ancient one of the image as a visible sign of a sacred invisible and a new one of the image as a visible expression of the artist idea (of art) ${ }^{24}$.

Hamacher reports that the transformation of the collections "starts (...) by a loss: a loss of the context, of the function, of the value and of the perspective under which the objects are perceived" 25 . There is a desecration that made the objects emerge as objects. According to him,

That which Pomian $\left[{ }^{26}\right]$ characterizes as loss of the role is nevertheless, as he admits, a loss that is common in the context of social and technical development

${ }^{21}$ EBERLEIN, J. “The Curtain in Raphael's Sistine Madonna”, p. 72.

22 "Fantasia, in the thinking of the time, was a promise of a freedom that causes the subject to experience himself or herself. Fantasy is also the source of the artistic idea, whether called disegno, concetto, or idea. In Raphael's time this idea was either 'the notion of a beauty transcending nature' or that of 'a pictorial form independent of nature' ". BELTING, H. Likeness and presence, p. 484.

${ }^{23}$ BELTING, H. Likeness and presence, p. 472.

${ }^{24}$ There were also interpretations that tried to conciliate both. Cf. Belting, H. Likeness and presence.

${ }^{25}$ My translation of: "commence (...) par une perte: perte du contexte, de la fonction, de la valeur et de la perspective sous lequels sont perçus les objets". HAMACHER, W. "Le dépouillement: Expositions de la mère", p. 97.

${ }^{26}$ Hamacher is referring to Krzystof Pomian's book Collectionneurs, amateurs et curieux in which the Polish philosopher and historian dissert on the transformations that lead to the museum advent. 
(...). It [the object] could not then be considered for conservation but for two reasons: be it its historical value, be it its artistic value ${ }^{27}$.

The work gets detached from the temple, from its original site, and becomes susceptible of displace and public exhibition. The mother as placental origin is a metaphor of this original site linked to worship. The temple is the site of the sacred, whereas the museum is the locus of the work of art. Leveled in the exhibition $^{28}$, the works lose their world. This process of becoming objects is inherent to what Heidegger is criticizing as the impossibility of the work of art to unfold its essence. According to him, "that the Sistine Madonna had become a work of art and worthy of a museum is part of the history of art since

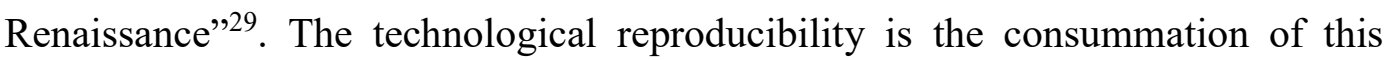
emancipation, of this objectification and of the forgottenness of the originary character of art as techne, that is: the ability to set Being into work. For Heidegger, "The museum kind of representation levels everything in the uniformity of exhibition [Austellung]"30.

The displace of art from the temple is related to the loss of art's originary character. I will try to make clearer that to put its essence authentically into work again would mean to make it (and us) dwell again in the unapparent, as an originary site. Heidegger, in the text On the Sistine Madonna, says that the word Bild is there to mean Antlitz (countenance) and that this Bild is an Altar-Bild. I will focus in these two central aspects in order to develop what would mean this Bild to remain being, though transformed, a sui generis Bildwesen.

\footnotetext{
${ }^{27}$ My translation of: "Ce que Pomian caractérise comme perte du role est cependant, comme il le concede, une perte qui est normale dans le cadre du development social et technique (...). On ne peut donc plus le prend en consideration pour la conservation que pour deux raisons: soit la valeur $<<$ historique $>>$, soit la valeur $<<$ artistique $>>$ ". HAMACHER, W. "Le dépouillement: Expositions de la mère", p. 97.

${ }^{28}$ It is worth calling attention that artists as Duchamp have tried to constantly maintain this issue at stake in their work, as he did with the Fountain. By provoking the displacement of questioning, they try to maintain art alive (and bring it back to its homeland? To build them a world?). According to Heidegger, "To bring to language ever and again this advent of being that remains, and in its remaining waits for human beings, is the sole matter of thinking. For this reason essential thinkers always say the Same. But that does not mean the identical" (Pathmarks, p. 275.) Original: "Diese bleibende und in ihrem Bleiben auf den Menschen wartende Ankunft des Seins je und je zur Sprache zu bringen, ist die einzige Sache des Denkens. Darum sagen die wesent-lichen Denker stets das Selbe. Das heißt aber nicht: das Gleiche". GA 9 [193], p. 363.

${ }^{29}$ My translation. Original: "Da $\beta$ die Sixtina zum Tafelbild geworden und museal; darin verbirgt sich der eigentliche Geschichtsgang der abendländischen Kunst seit der Renaissance”. GA 13, p. 119.

${ }^{30}$ My translation. Original: "Das museale Vorstellen ebnet alles ein in das gelichförmige der $>>$ Ausstellung <<". GA 13, p. 120.
} 
I intend to argue that in the Sistine Madonna there is an enowning (Ereignis) of the mutual belonging of concealment and unconcelament. I will defend that this is what gives this painting its singular character as a Bildwesen, an image essencing. As it was mentioned, in this painting, the "Bild bildet", the form forms, the bringing into emergence (her-vor-bringen) brings into emergence. Heidegger states that this essencing, as this "Bild bildet", brings into emergence both a window and the site (Ort) of alétheia. The Bild as Antlitz is related to the bringing into emergence of a window and the Bild as Altar-Bild is related to the bringing into emergence of a site. The dissertation will be divided in two chapters, according to these relations to be investigated.

The first chapter will address Heidegger's characterization of the Bild as Antlitz. The philosopher specifies his use of Antlitz (countenance) as meaning an Entgegenblick, an "en-countering looking"31, or, literally, a glance turned toward $^{32}$, that is, toward an encounter. This is important to support my interpretation of the singularity of this painting, since Entgegenblick is related to a kind of face to face glimpse. Heidegger said that a window is a glimpse into the outside. That this window is an out-look (Ausblick) means that it is what looks. A unique out-look takes place. The image as a bringing into emergence brings forth a window as the openness of a disclosure. The mutual reference of the image (Bild) and the window evokes the invisible horizon of a mutual belonging that emerges. Being the "outlook of arrival", the Sistine as window is the outlook of a mutual bringing of the Virgin Mary and the Infant Jesus. This window looks then at a mutual belonging of both, since the mother is only mother by being daughter of her Son. The mutual belonging as the affinity of what conceals and unconceals itself will be addressed as inherent to the structure of the truth as alétheia. Heidegger's text Language will be crucial to support the intimacy of this interplay. The mutual bringing that happens in the Sistine Madonna is then a very special one, since, we could say, it looks at itself. I will defend that there is kind of face-to-face of mutual belongings indicated by the image (Bild) forming a window and the mutual bringing of mother and Son.

\footnotetext{
${ }^{31}$ In: RADLOFF, B. Preliminary notes on divine images, p. 155.

32 "an 'entgegen', a 'toward”". See MITCHELL, A. "Translator's foreword". In: Bremen lectures, p. xiii.
} 
Still in this chapter on the Bild as Antlitz (countenance), I will dig into the meaning of Entgegenblick as related to a glimpse toward an unapparent appearing placed before the eyes. This characterization brings us to the Heideggerian notion of Ereignis, which might also be related to a placing before the eyes (eräugnen). Ereignis refers to a disclosure of appropriation in which the mutual belonging is brought into emergence. I will bring into consideration that the word 'countenance' might be related both to semblance as the look of something and to that which sounds through everything. It is possible to trace these senses in the meaning of face as mask, persona, which also refers to a per sonare, a sounding through, as a voice that sounds through a mask. The reference to the mask and to that which sounds through it will lead the discussion again to the issue of a mutual belonging. The aim is to make clear that this intimacy of concealment and unconcealment, being the provenience of all things, sounds through everything. This is important because, since such mutual belonging is inherent to all being, it is also the relation of each thing to it that will give something its singular character, its authenticity.

The investigation on the second relation formerly mentioned, namely the Bild as Altar-Bild as related to the bringing into emergence of the site (Ort) of alétheia, will help to enlighten the previous statement. The second chapter will then revolve around the issue of the Bild as Altar-Bild. According to Heidegger, the site is always an altar. When Heidegger characterizes the Sistine as an AltarBild, he intends to singularize this image as an originary Bild. There is again an important mutual belonging involved. This time what is at stake is the mutual belonging of the Bild to a church and of the church to a Bild. I will argue that the intimacy between them is also pointing to a relation of the mutual belonging to itself. These time through the relation between two sites: the altar and the Church. Since this Bild is an Altar-Bild, we may also take it as an altar.

Heidegger's text Language and homeland (Sprache und Heimat) will be important to support the connection between both sites. The belonging to an originary site might be related to a belonging to a homeland and, according to the philosopher, "The homeland does not exist on this Earth [my highlight]"33. The homeland is always destiny. It is related to the truth as alétheia. When language is

\footnotetext{
${ }^{33}$ My translation. Original: "D i e Heimat gibt es nicht auf dieser Erde". GA 13, p. 156.
} 
authentically in its essence, it is authentically in the truth of Being. When these happens, language is also the house of Being. Heidegger concludes his text suggesting that language is language as homeland. I will then develop the idea that the altar as the site of the memory of the sacred is related to man as an altar. Once man thinks the mutual belonging inherent to the truth as alétheia, he becomes an altar.

It will also be important to highlight that there is an intimacy between the singularity of this Bild and the singularity of "the unapparent site" of a certain church $^{34}$. I will argue that the temple is a homeland as the unapparent. The homeland "does not exist on this Earth" as much as the site seems to be "unapparent". They are both destinies. According to Heidegger, the Sistine Madonna does not belong to a church in Piacenza "in the sense of the history of antiquarian"35. The belonging of the image to a church is related to its "essencing as Bild"36. The vinculum between the altar and the church is as the marriage vinculum, an unapparent mutual belonging. According to the Bible, both the altar and the temple are related to that which makes sacred ${ }^{37}$. I will suggest that they are united in their essence as a singular provenience of authenticity. Transubstantiation, as the mystery that takes place in the altar, is a mystery of the memory of the sacred as a seeing of the unapparent appearing of the incessant rise of physis. To behold this originary seeing would be to dwell in such unapparent appearing. I intend then to achieve the conclusion that this Bild as an enowning (Ereignis), that is, as the unapparent appearing of the mutual belonging of concealment and unconcealment, indicates the path of an authentic thinking. Its uniqueness comes from its relation to the provenience of all being, that is, to all that, as Mary, bears life.

\footnotetext{
${ }^{34}$ See GA 13, p. 121. See chapter 2. "To the singular [einzigen] event of the image necessarily corresponds its singularizing [Vereinzelung] in the unapparent [unscheinbaren] site [Ort] of a Church among many others". My translation. Original: "Dem einzigen Geschehnis des Bildes entspricht notwendig seine Vereinzelung an den unscheinbaren Ort der einen unter den vielen anderen Kirchen".

${ }^{35}$ My translation. Original: "[nicht] in einem historisch-antiquarischen Sinne”. GA 13, p. 120.

${ }^{36}$ My translation. Original: "Bildwesen nach". GA 13, p. 120.

${ }^{37}$ Mt 23, 16-22. See chapter 2.
} 
Finally, I would like to clarify that this dissertation's aim is not to be a text on Heidegger ${ }^{38}$. It would be great if this work could help to elucidate in a certain extent a few features of Heidegger's thought. My purpose, however, is to think starting from Heidegger's clues on the issue of the Bild. To try to do justice to Heidegger's thought is not to reproduce his thinking but to try to think genuinely. These pages are an effort to engage in such an authentic thinking.

The authentic interpretation must show what does not stand there in the words and which is nevertheless said. For this the interpretation must necessarily use violence. What is authentic is to be sought where nothing further can be found by scientific exegesis, which brands as unscientific everything that exceeds its domain ${ }^{39}$.

This way might be a wandering one ${ }^{40}$, but it would remain the only truly faithful to thinking. Heidegger defends that if the author "does not say it; therefore, we must specifically think it and append it via poetizing"41.

\footnotetext{
38 As it is known, there is not much secondary bibliography on the issues treated in this dissertation. Heidegger himself does not develop further many of his statements on his text On the Sistine Madonna.

${ }^{39}$ IM [124], p. 173. Original: "Die eigentliche Auslegung muß jenes zeigen, was nicht mehr in Worten dasteht und doch gesagt ist. Hierbei muß die Auslegung notwendig Gewalt brauchen. Das Eigentliche ist dort zu suchen, wo die wissenschaftliche Interpretation nichts mehr findet, die alles, was ihr Gehege übersteigt, als unwissenschaftlich brandmarkt". GA 40 [124], p. 171.

${ }^{40}$ Or an Irrgang. See GA 7 [134].

${ }^{41}$ Poverty, p. 6. Original: "sagt es nicht; darum müssen wir es eigens denken und $d . h$. hinzudichten”. GA 73, p. 877.
} 


\section{2 \\ The Bild as Antlitz}

Certainly, speculari is also a seeing, but it is a non-sensible one. ${ }^{42}$

Martin Heidegger

Before expression, there is nothing but a vague fever, and only the work itself, completed and understood, will prove that there was something rather than nothing to be found there ${ }^{43}$.

The painter recaptures and converts into visible objects what would, without him, remain walled up in the separate life of each consciousness: the vibration of appearances which is the cradle of things ${ }^{44}$.

Maurice Merleau-Ponty

'Over all the peaks / is peace': (...) Goethe wrote [those verses] in pencil on the window frame of a hut ${ }^{45}$.

Martin Heidegger

Not only due to its reference to incarnation, The Sistine Madonna evokes the limits of understanding. It is "pure mystery brought into image" reinforces the enigmatic character of appearing. The curtains open a space and

\footnotetext{
${ }^{42}$ My translation. Original: "Freilich ist speculari auch ein Schauen, aber ein unsinnliches". GA 13, "Über die Sixtine", p. 120.

${ }^{43}$ In: MERLEAU-PONTY, M. "Eye and mind". In: The Merleau-Ponty Aesthetics Reader: Philosophy and Painting, p. 69. Original: "Avant l'expression, il n'y a rien qu'une fièvre vague et seule l'œuvre faite et comprise prouvera qu'on devait trouver là quelque chose plutôt que rien". In: MERLEAU-PONTY. "Le doute de Cézanne". In: Sens et non-sens, p. 26.

${ }^{44}$ In: MERLEAU-PONTY, M. "Eye and mind", p. 68. Original: "Le peintre reprend et convertit justement en objet visible ce qui sans lui reste enfermé dans la vie séparée de chaque conscience: la vibration des apparences qui est le berceau des choses". In: MERLEAU-PONTY. "Le doute de Cézanne”. Sens et non-sens, p. 25.

${ }^{45}$ IM [68], p. 94. It follows: "on the Kickelhahn near Ilmenau”. Original: “ "Uber allen Gipfeln / ist Ruh'; (...) jene (...) Verse, die Goethe mit Bleistift an den Fensterpfosten eines Bretterhäuschens auf dem Kickelhahn bei Ilmenau geschrieben". GA 40 [68], p. 96.

${ }^{46}$ My translation. Original: "Ela [A Madona Sistina] é puro mistério feito imagem". In: GUTIERREZ, M. Um lavrar luminoso, p. 4.
} 
withdraw the key of its secrets. One of Raphael's masterpieces, it has caught Goethe's, Nietzsche's and many other notorious thinkers' attention ${ }^{47}$. It was however through a transversal way that the Sistine has arrived in Heidegger's pen. Almost driven by the circumstances of discussing one of his students, Marielen Putscher, thesis, the philosopher has finally addressed a few words to the famous Madonna $^{48}$. A section of a letter he sent her was published as an afterword ${ }^{49}$ to her work.

Despite the reasons that brought him to the painting, Heidegger has recognized its importance and peculiarity. In his text On the Sistine Madonna (Über die Sixtine), he characterizes it as a Bild (image ${ }^{50}$ ) in a very special sense. The first clue he gives is that this word is there to mean 'countenance' ${ }^{51}$, Antlitz. He does not use the ordinary German word for face, Gesicht, he chooses Antlitz. This choice points to a careful attention to what he is about to outline. Besides not being very usual, Antlitz has also an exquisite character, since it is more frequent in literary and religious contexts. The astonishing employment seems to require a clarification. Heidegger himself tries to help us. As the philosopher says, he

\footnotetext{
${ }^{47}$ In Ladwein's Raffaels Sixtinische Madonna, there is a collection of quotations in which the Sistine Madonna is mentioned.

48 "Ce texte est le fruit de longs et nombreaux entretiens entre Heidegger et Marielen Putscher, qui, après avoir suivi l'enseigment de ce dernier à Freiburg, a consacré un travail importante à la Madonne Sixtine. En témoignage amical de ce questionemment commun, Heidegger a accepté de rédiger ce petit texte, publié en guise de posface à la monographie en question." MAVRIDIS, M. (translator). In: HEIDEGGER, M. "Sur la Madone Sixtine". In: Po\&sie. N. 81. September 1997. Besides this French translation in Po\&sie, there is another one in Lacoue-Labarthe's text La vraie semblance, 2008 - p. 23-27. Putscher's thesis, in which Heidegger's text on the Sistine was first published, is called Raphaels Sixtinische Madonna. The text Über die Sixtine is published in Heidegger's Gesamtausgabe 13, Aus der Erfahrung des Denkens - p. 119-121. In the Ladwein's Raffaels Sixtinische Madonna - Literarische Zeugnisse aus zwei Jahrhunderten, there is a full reproduction of this Heidegger's text. There are two Portuguese translations available: one by Irene Borges Duarte in Arte como epifania, 1989 - p. 74-77 -, and another one that is printed in Lacoue-Labarthe essay in Mimesis e expressão, edited by Rodrigo Duarte e Virginia Figueiredo, 2001 - p. 21-23. In 2011, an Italian translation by Nicola Curcio was released in Dall'esperienza dell pensiero 1910-1976, p. 103-105. In 2014, a Spanish translation by Francisco de Lara was published in Experiencias del pensar (1910-1976) - p. 81-84.

49 "Dieser letzte Absatz ist einem Briefe Heideggers entnommen, den ich $>>$ mit dem Vorbehalt, $\mathrm{da} ß$ es nur beiläufige Gedanken eines Unzuständigen seien $<<$, meiner Arbeit anfügen durfte”. In: PUTSCHER, M. Raphaels Sixtinische Madonna, p. 174. "This last section, which I could attach to my work - with the proviso that it will be taken just as provisory remarks of a non-specialist - , has been extracted from a letter from Heidegger".

${ }^{50}$ Bild is usually translated by image or picture. Heidegger, however, proposes a specific way to understand it, that is as a bringing into emergence (hervorbringen). This characterization will be discussed in due course in this text.

${ }^{51}$ The French translation uses "figure". The Italian translation uses "cospetto". The Spanish translation uses "semblante". The Portuguese translation uses "rosto". The Kluge, an etymological dictionary of the German language, has a translation to English that suggests "countenance" as a possible correspondent to Antlitz.
} 
means Antlitz "in the sense of [an] en-countering looking as arrival" 52 , that is, a "looking" that invites us to an experience in which to see and to be seen may happen.

To address the possibilities of seeing is to address the conditions of visibility itself. What is at stake in the analogy of visibility is the thinging of things, the mystery of life. It was once said that "the face (...) is a silent language" $" 53$. This broad sense of language in which gestures become meaningful is inspired by an experience of limit. The impossibility of language to say explicitly and directly its own being reminds us of the paradox of the eye that cannot see itself. The issue of the conditions of visibility and the discussions on the limits of language are all pointing to a similar difficulty. It is not just the hardness of approaching these subjects. It is mainly the disconcerting fact that what conceals itself also appears. Concealment and unconcealment happen together. This twofoldness points to the horizon of the own possibility of seeing. The eye cannot see itself seeing ${ }^{54}$, but it sees. It sees what appears and senses the unapparent, what it could not literally see, but that it suspects from its capacity of seeing. It glimpses the tension of this twofold, of this path over itself.

In Greek Mythology, this dangerous endeavor used to be associated to death. Not being able to see the Gods directly can be related to not being able to see this sacred aspect. Even the mirror does not properly solve the problem. This artificial way of trying to overcome this impossibility is no guaranty of success. It could also lead to curses as in the case of Narcissus, that sees his reflection ${ }^{55}$ on a water surface ${ }^{56}$. The self-reference of the mirror leads to a return back to what is

\footnotetext{
52 This passage is translated by Radoloff in "Preliminary notes on divine images", p. 155. Original: "im Sinne von Entgegenblick als Ankunft". GA 13, p. 119. See also GA 12 [46], p. 42: "Antlitz, d.h., Gegenblick". My translation: "countenance, that is, countering glance". And GA 12 [48], p. 44: "sein eigenes Antlitz, seinen Gegenblick", "his own countenance, his countering glance" ("Language in the poem", p. 169). For other quotes, see GA 12 [61]; [64]; [66]; [76].

${ }^{53}$ Original: "Le visage (...) est le silenciaux langage". CHEVALIER, J. \& GHEERRBRANT, A. Dictionnaire des symboles, p. 1023.

${ }^{54}$ See "The inability of human beings to see themselves corresponds to the self-concealment of the lighting of being". Off the Beaten track, p. 254. Original: "Das Sichversehen des Menschen entspricht dem Sichverbergen der Lichtung des Seins". GA 5 [311], p 337.

55 "The drama of Narcissus, the drama of the image, is not that he could only see himself but rather that he could never see himself, he could never see the seeing, but only the seen, the imaged". SCHUBACK, M. "The ficiton of the image", p. 73.

${ }^{56}$ The English word 'surface' also seems to indicate a relation to a façade, what directs us to the meaning of seeing ourselves on other's face or the water's sur-face in this case. It might be worth thinking possible relations of this meaning to Heidegger's use of 'Entgegenblick'.
} 
in front of it. Such return to itself has also been described as a distinctive aspect of appearing understood as what reflects the creative intelligence.

This original wisdom was described by Augustine and rethought by Leibniz through the analogy of the mind that reflects on itself. This movement of thinking is related to the issue of unity and multiplicity. The attempt of understanding itself allows us to consider the mind as much as 'that which understands' as 'that which is understood'. This distinction lets see two different properties: the power of perceiving (vis percipiendi) and the power of manifesting (vis exhibendi). This binity $^{57}$ related to the mind was thought in a special way in the case of the Christian God. Since only in Him there is a true Trinity, the understanding (intellectio) “is also a 'perpetual subsisting' thing (perpetuum quiddam at subsistens) ${ }^{\$ 58}$. Once again, there is a limitation concerning human understanding. There is a divine character involved in understanding, which restricts it to what is also divine.

According to Vasiliu, "For the ancients the face-to-face was nothing but the maximal expression, an exposition $\left[{ }^{59}\right]$ in zenithal light of the natural relation between the act and the passion engendered when the agent also becomes the patient of his act" 60 . In astronomy, zenith is related to "the point on the celestial sphere vertically above an observer" ${ }^{\prime \prime}$. In a wider sense, it might refer to "the highest point" of "someone's achievements" ${ }^{2}$. Once given the impossibility of an original face-to-face, and the misleading metaphysical way of interpreting it in terms of subject and object ${ }^{63}$, Heidegger's words resonate here in a special tone. In the text On the Sistine Madonna, he says that "The following remarks [or

\footnotetext{
${ }^{57}$ Binity of the person thinking (persona intteligens) and the person thought of (persona intellecta).

${ }^{58}$ ANTOGNAZZA, M. "Leibniz de Deo Trino: philosophical aspects of Leibniz's conception of the Trinity", p. 8.

${ }^{59}$ As a glorious shine? See p. $44 \mathrm{ff}$.

${ }^{60}$ VASILIU, A. "Eikôn Praeter Imaginem: notes sur le vocabulaire de l'image à la fin de l'antiquité", p.779. Original: "Pour les Anciens le face-à-face n'est rien d'autre qu'une expression maximale, une exposition en lumière zénithale de la relation naturelle entre l'acte et la passion engendrée dès lors que 1'agent devient aussi patient de son acte".

${ }^{61}$ In: http://dicionario.reverso.net/ingles-definicao/zenith at 06/18/2016.

${ }^{62} \mathrm{In}$ : http://dicionario.reverso.net/ingles-definicao/zenith at 06/18/2016.

${ }^{63}$ As Nietzsche would say: we have taken the metaphor too literally. Since this that is subject to a face-to-face, although appears, is unapparent, there is no literal meaning, or at least no completely literal one. I say completely, because although it is unapparent, it does happen in a certain way in appearing, that is, through it.
} 
considerations] are nothing but $>>$ speculations $<<$. Certainly, speculari is also a seeing, but it is a non-sensible one" ${ }^{" 64}$. Speculari derives from

Speculum (mirror) [which] has given the noun 'speculation': in its origin, 'to speculate' means to observe the sky and the relative movements of the stars with the help of a mirror. Sidus (star) has equally given 'consideration' that etymologically means to see the cluster of stars. These two abstract words, that mean nowadays operations that are highly intellectual, have their root in the study of stars reflected on mirrors ${ }^{65}$.

Heidegger's remarks could be understood as speculations in the sense of trying to reflect on the mystery of an unapparent appearing. They are nothing but speculations, since what they address is not susceptible of an ordinary look or been exhausted. The seeing which concerns him is a seeing related to another temporality, the one of the "presencing as Bild"66.

For Heidegger, "In the Bild, as this Bild, it happens the appearing of the becoming man of God" ${ }^{\prime}$. Merleau-Ponty says that "Artists have often mused upon mirrors because beneath this 'mechanical trick', they recognized, as they did in the case of the 'trick' of perspective, the metamorphosis of the seeing and the seen that defines both our flesh and the painter's vocation" ${ }^{68}$. Again: it is the definition of our flesh, of what we are. The thinging of things happens in the Sistine Madonna as incarnation. The becoming man of God is seen in the painting under this perspective of a play of glances and points of view. Heidegger says that the ownmost of the bringing of both, of the mother and of her Son, is gathered "in the glancing look" ${ }^{69}$. It concerns the seeing of this twofold of the seeing and the

\footnotetext{
${ }^{64}$ My translation. Original: "Darum bleiben die folgenden Bemerkungen $>>$ Spekulationen $<<$. Freilich ist speculari auch ein Schauen, aber ein unsinnliches". GA 13, "Über die Sixtine", p. 120.

${ }^{65}$ My translation. CHEVALIER, J. \& GHEERRBRANT, A. Dictionnaire des symboles, p. 635. Original: "Speculum (miroir) [qui] a donné le nom de spéculation: à l'origine, spéculer c'était observer le ciel et les mouvements relatifs des étoiles, à l'aide d'un miroir. Sidus (étoile) a également donné considération, qui signifie étymologiquement regarder l'ensemble des étoiles. Ces deux mots abstraits, qui désignent aujourd'hui des opérations hautement intellectuelles, s'enracinent dans l'étude des astres reflétés dans des miroirs".

${ }^{66}$ RADLOFF, B. "Preliminary notes on divine Images", p. 146.

${ }^{67}$ My translation. Original: "Im Bild, als dieses Bild geschieht das Scheinen der Menschwerdung Gottes". GA 13, p. 121.

${ }^{68}$ MERLEAU-PONTY, M. "Eye and mind", p. 130. Original: "Les peintres ont souvent rêvé sur les miroirs parce que, sous ce «truc mécanique» comme sous celui de la perspective, ils reconnaissaient la métamorphose du voyant et du visible, qui est la définition de notre chair et celle de leur vocation". In: L'oeil et l'esprit, p. 22.

${ }^{69}$ My translation. Alternative: "in the seeing [of the] glance". Original: "in das blickende Schauen". GA 13, p. 121.
} 
seen. The Madonna's figure with the Child is facing the window and, by this standing before, which might also be a standing before the spectator, Mary's attitude invites the viewer to face what she sees. It is an invitation to engage on this path, on this way of seeing, on the route of this distance that tensions the one who sees, be it the spectator or the virgin ${ }^{70}$, and what is seen or glimpsed. According to Sallis, "There is a compounding and an intensification of the look when it is the look of one who is looking, when it is a look that is not merely seen but that, in its very look, looks back and is seen as seeing"71. This is precisely what Raphael's painting portraits in Mary's figure. Nevertheless, the Madonna looks back in a very special way. She seems not to be focusing something visible $^{72}$, but rather she seems to be staring what has an unapparent character. Her eyes wonder at an in-between.

It is interesting to notice that besides arguing that this metamorphosis of the seeing and the visible is the definition of our flesh, Merleau-Ponty also characterizes it as the painter's vocation. The philosopher adds that their work is

This two-dimensional being, which makes me see a third, is a being that is pierced [troué] - as the men of Renaissance said, a window... But in the final analysis the window opens only upon partes extra partes, upon height and breadth merely seen from another angle - upon the absolute positivity of Being ${ }^{73}$.

It is a pierced being...: a window. This two-dimensional being, the painting, makes us see another dimension, a third. An unapparent dimension that, nevertheless, appears and let see. In the openness of this pulling of curtains, the appearing of the divine withdraws. It is not just Mary's figure that engages on a look. The window is the outlook, it is what looks. It looks outward in the direction

\footnotetext{
${ }^{70}$ Or even the own window as it will be discussed, although in a slight different way. Since what is at stake is Ereignis, a disclosure of appropriation, as it will be elucidated, the invitation is a call for a transformation, for a let shine through.

${ }^{71}$ SALLIS, J. "The look of things", p. 3.

${ }^{72}$ In Portuguese, we would say "olhando para o vazio" ou "para o nada" ("staring the empty", "the Nothing" or maybe "looking into the emptiness"). In English, the closer expression might be "to have empty eyes". The connotation of having no expression might be connected to the unapparent character of what is being faced.

${ }^{73}$ MERLEAU-PONTY, M. "Eye and mind", p. 134. Original: "Cet être à deux dimensions, qui m'en fait voir une autre, c'est un être troué, comme disaient les hommes de la Renaissance, une fenêtre... Mais la fenêtre n'ouvre en fin de compte que sur le partes extra partes, sur la hauteur et la larguer qui sont seulement vues d'un autre biais, sur l'absolue positivité de l'Être". In: L'oeil et l'esprit, p. 28.
} 
of an arrival ${ }^{74}$. The window faces Mary and her son mutual bringing. This peculiar window that the Sistine is insists on the matter. It insists on the mystery of the sacred, a mystery of mutual belonging. According to Heidegger, "By thinging, things carry out world. Our old language calls such carrying bern, bären - Old High German beran - to bear; hence the words gebaren, to carry, gestate, give birth, and Gebärde, bearing, gesture. Thinging, things are things. Thinging, they gesture - gestate - world"75. To hold in her womb is to experience something as part of herself. It is a welcome of the issue of a mutual bringing. Further on, Heidegger continues: "For world and things do not subsist alongside one another. They penetrate each other. Thus the two traverse a middle. In it, they are at one. Thus at one they are intimate" ${ }^{96}$. The intimacy of the relationship between mother and son gather both and separate them. Their original unity is being in relation to one another. In the case of the Sistine Madonna, there is a special kind of motherhood. There is a mutual bringing in which the mother can only be mother by being daughter of her Son. Despite their distance, they are united by intimacy. This mutual bringing is also described by Heidegger in the following way:
Maria bring (bringt) the Infant Jesus in a way that it is only through Him that she is herself brought forth (her-vor-gebracht) in her arrival (Ankunft), which at each time brings with (mit-er-bringt) it the sheltering concealment $\left[{ }^{77}\right]$ (das verborgen Bergende) of its provenance (Herkunft $^{78}$.

Heidegger clearly wants to establish a relation between:

\footnotetext{
${ }^{74}$ See the following quote. My Translation: "The window as admission of the approaching shinning is the outlook of arrival". Original: "Das Fenster als Einla $\beta$ des nahenden Scheinens ist Ausblick in die Ankunft". GA 13, p.120. See note 82.

75 "Language", p. 197. Original: "Die Dinge tragen, indem sie dingen, Welt aus. Unsere alte Sprache nennt das Austragen: bern, bären, daher die Wörter »gebären« und »Gebärde«. Dingend sind die Dinge Dinge. Dingend gebärden sie Welt". GA 12, [22], p. 19.

76 "Language", p. 199. Original: "Denn Welt und Dinge bestehen nicht nebeneinander. Sie durchgehen einander. Hierbei durchmessen die Zwei eine Mitte. In dieser sind sie einig". GA 12, [24], p. 21-22.

${ }_{77}$ I am following Radloff suggestion of translation for this expression. See RADLOFF, B. "Preliminary Notes on Divine Images in the Light of Being-Historical Thinking", p. 156.

${ }^{78}$ My translation. Original: "Maria bringt den Jesusknaben so, dass sie selbst erst durch ihn hervor-gebracht wird in ihre Ankunft, die in sich jeweils das verborgen Bergende ihrer Herkunft miter-bringt”. GA 13, Über die Sixtine, p. 120.
} 
1) "bringen" (to bring), "hervorbringen" (to bring forth) and "miterbringen" (to bring with);

2) "verborgen" (in a hidden manner, concealed, secretly, quietly) and

"Bergende" (sheltering, concealing, gathering);

3) "Ankunft" (arrival) and "Herkunft" (provenance, coming from).

The first group of words stresses how the appearing as a bringing forth always brings with it a structure of mutual bringing. To bring is to appear in a mutual bringing structure, which is always the way in which being happens. The mutual bringing is a bringing in which what appears conceals its provenance, it is a bringing that brings a concealment and an unconcealment. This mutual bringing is always a bringing forth, since it is always related to an unconcealment, a making appear, even if concealing its provenance. To bring is always pointing then to a mutual bringing as a mutual belonging of concealment and unconcealment. This mutual belonging characterizes the structure of alétheia that concerns all being.

The mutual bringing of Mary and her Son, the intimacy of carrying Jesus and carrying out world and the interweaving of arrival and provenance are stressed in the expression "das verborgen Bergende", "the sheltering concealment". The coming to light is always penetrated by darkness. The loss of ground of this provenance is claimed by the concealed aspect involved on it. In a hidden manner, secretly, that is, in a quiet way, the Madonna shelters its provenance. She does it "quietly gathering", as I would suggest interpreting it. Heidegger wants to think the incarnation that takes place in the Sistine Madonna not as an objectification of Being but in the light of the structure of alétheia.

It is well known that there are several elements on the Sistine canvas that refer to a transition as if from heaven to earth, as for example: the clouds, the veil filled by air and Mary's descending steps. Her arrival (Ankunft) evokes her coming from or her provenance (Herkunft). This relation is highlighted by Heidegger's choice of words. The interweaving of both terms links the carrying of 
Jesus $^{79}$ to the carrying out of world. The tension between sky and earth, and between provenance and arrival, let us see beings in their shine ${ }^{80}$, let us see "the unapparent tensional realm of in-betweens" $" 81$.

This tension reminds us of another one: the tension of the exchange of glances that is characteristic of the Bild as Antlitz (countenance). "Antlitz (...) is (...) the moment (Augenblick) of arrival and mutual 'recognition' in the exchanging of a glance. This implies a mutual openness within a site of openness" $"$. The window as this possibility of exchange is an encountering glance (Entgegenblick), an encountering glance as arrival (Entgegenblick als Ankunft). "The window as admission of the approaching shining is the outlook of arrival" The window enables the view of arrival. It grants the possibility of the nearness of appearing in its shining. Heidegger mentions another window, Trakl's window, in $A$ Winter Evening (Ein Winterabend) ${ }^{84}$ and characterizes the possibility of exchange it involves in the following way: "The thing outside touch[es] the things inside the human homestead" ${ }^{\prime 25}$. The visible canvas instigates the invisible spectator. The visibility of things evokes the invisibility of seeing. Once again there is a mutual reference between the two sides or aspects related. This mutual reference penetrates everything.

On the Sistine canvas, Pope Sixtus invites the spectator to participate in what is going on by the gestures of his hands. One of his hands points to the direction of the spectator ${ }^{86}$, the other one to his heart. Discussing a line of one of Hölderlin's poem, Heidegger argues that "with his heart", "am Herzen”, means to "come to the dwelling being of man, come as the claim and appeal of the measure

\footnotetext{
${ }^{79}$ It is worth having in mind His relation to Incarnation as the sky that comes to Earth or the sky in Earth. The Trinity is also thought of as a way of understanding the carrying out of world. Frémont uses the expression "exercise of the Trinity" to characterize the world's flow of continual becoming. See Introduction of $L$ 'être et la relation.

${ }^{80}$ let us see the $D a$ of Da-sein?

${ }^{81}$ SCHUBACK, M. "The fiction of image", p. 81.

${ }^{82}$ RADLOFF, B. "Preliminary notes on divine images", p. 155.

${ }^{83}$ My translation. Original: "Das Fenster als Einlass des nahenden Scheinens ist Ausblick in die Ankunft". GA 13, p. 120. Radloff's translation: "The window as admission of a shining-forth bringing closeness is glimpse of arrival", p. 156.

${ }^{84}$ See GA 12, [17], p. 14.

85 "Language", p. 194. Original: "Das Draußen rührt an das Drinnen der menschlichen Wohnstatt". GA 12, [18], p. 16.

${ }^{86}$ Pay attention that it is also the direction of the window.
} 
to the heart in such a way that the heart turns to give heed to the measure" ${ }^{" 87}$. What is at stake is a vital intensity. It is life that calls for attention.

Each one who is must, as far as he is, be in such a way that he rises up against the own rising, in such a way that each one in his rising stands towards physis. (...) One glimpses into the clearing and this glimpse is its $Z o e,,>>$ Life $<<$, we say. The Greeks, however, think thereby the rising as the being. ${ }^{88}$

Still concerning Trakl's poem Ein Winterabend, there is a line that says: "Golden blooms the tree of graces" "89. Heidegger brings up Pindaro's characterization of gold as Periósion pánton in order to enlighten this golden. According to the German philosopher, this golden refers to "that which above all shines through everything, panta, shines through each thing present all around. The splendor of gold keeps and holds everything present in the unconcealedness of its appearing" 90 . The Pope is wrapped in a golden mantle. The Pope who is the rock in which the temple is grounded. As it is known, Peter, whose name means rock, stone ${ }^{91}$, was the first pope. To accept this cathedra is to inherit its task which involves a holy $\operatorname{se}^{92}$. To be engaged in such a seeing is to transform ourselves and measure our gestures with it. "The rock is the mountain sheltering pain"93. A mountain is the earth rushing itself to the $\mathrm{sky}^{94}$. But what does pain mean here?

Heidegger says that "Pain has turned the threshold to stone" stone. Pain refers to a rift, which is a cleft, an outline, that enables the rise of the lighting of beings. The frame outline an openness. "The threshold is the groundbeam that bears the doorway as a whole. It sustains the middle in which the two, the outside and the inside, penetrate each other. The threshold bears the [in-

87 "Poetically", p. 227. Original: "angekommen beim wohnenden Wesen des Menschen, angekommen als Anspruch des Maßes an das Herz so, daß dieses sich an das Maß kehrt". GA 7. [198], p. 208.

${ }^{88}$ My translation. Original: "Jedweder, der ist, muß, sofern er ist, so sein, daß er aufgeht gegen das Aufgehen selbst, daß jedweder aufgehend zur physis sich verhält. (...) er blickt in die Lichtung, und dieses Blicken ist seine Zoé; »Leben« sagen >wir $<$. Die Griechen jedoch denken dabei das Aufgehen als das Sein". GA 55, p. 173.

89 “Language”, p. 198. Original: "Golden blüht der Baum der Gnaden”. GA 12, [23], p. 20.

90 "Language", p. 199. Original: "das was alles, pánta, jegliches Anwesende ringsum, vor allem durchglänzt. Der Glanz des Goldes birgt alles Anwesende in das Unverborgene seines Erscheinens". GA 12 [24], p. 21.

${ }^{91}$ See Mt. 16, 18. In Aramaic, the word used is Kepha. In Greek, it is Petrus.

${ }^{92}$ The Pope is said to be inspired by the Holy Spirit.

93 "Language in the poem", p. 166. Original: "Der Stein ist das Ge-birge des Schmerzes". GA 12 [44], p. 45.

${ }^{94}$ See Kluge.

95 "Language", p. 192. Original: "Schmerz versteinerte die Schwelle". GA 12 [17], p. 15. 
]between"96. It is possible then to notice one more element of the canvas referring to an intimate in-between. It evokes Mary's title, "ark of the covenant", Foederis $\operatorname{arca}^{97}$. She carries the mysterious in-between in which the sky and the earth are at one. We could also remember one more of Mary's titles, namely: "gate of Heaven", Ianua caeli ${ }^{98}$. It might be linked to the threshold, to the window, to Mary's seeing, to Mary's given birth to Jesus, to the Pope's hand gestures and even to pain. All of them referring to an in-between of two related aspects, be it sky and earth or inside and outside, for example. Nevertheless, it is worth noticing that this outside is nothing but the arrival as the shining-radiance of beings. The position of the curtains, this important detail of Raphael's window, confirms such precious subtlety. It also implies that, from this point of view, Mary stares the "inside", she looks to this abyssal depth. The outside as arrival is intimate with the abyssal depth of the inside ${ }^{99}$. The curtains sustain this in-between, a middle. The mutual reference of the two brings them close and makes them intimate. By settling an in-between, a middle of two, "Pain is the joining agent in the rending that divides and gathers. Pain is the joining of the rift" 100 .

Once it is the joining of the rift, pain, also called "holy pain" ${ }^{101}$, might be related to a wound, one "full of graces"102. The openness of the wound is the own possibility of the nearness of these graces. "Pain is the dif-ference itself" 103 , which is the dimension that provides unifying intimacy. "Of itself, it [dif-ference] holds apart the middle in and through which world and things are at one with each other. The intimacy of the dif-ference is the unifying element of the diaphora, the carrying out that carries through"104. It is the openness to the seeing of the lighting

\footnotetext{
96 "Language", p. 201. Original: "Die Schwelle ist der Grundbalken, der das Tor im ganzen trägt. Er hält die Mitte, in der die Zwei, das Draußen und das Drinnen, einander durchgehen, aus. Die Schwelle trägt das Zwischen". GA 12 [26], p. 24.

${ }^{97}$ See Litaniae Lauretanae. It is not suggested here a metaphysical understanding of this title or the next ones. The interpretation that is going to follow aims to find the original naming force of these words that came to be read in a metaphysical way.

${ }^{98}$ See Litaniae Lauretanae.

${ }^{99} \mathrm{Cf}$. "One does not need to look outside one's window / To know the dao of heaven; / The farther one goes, / The less one knows. / [Understand] Without going anywhere out of the necessary". LAOZI Apud LIN MA, Heidegger on East-West Dialogue, p. 131.

100 "Language", p. 202. Original: "Der Schmerz ist das Fügende im scheidendsammelnden Reißen. Der Schmerz ist die Fuge des Risses". GA 12 [27], p. 24.

${ }^{101}$ See GA 12 [17], p. 15. Orignal: "heiligem Schmerz". Poetry, p. 193.

${ }^{102}$ See GA 12 [17], p. 15. Original: "Seine Wunde voller Gnaden". Poetry, p. 193.

103 "Language", p. 202. Original: "Der Schmerz ist der Unter-Schied selber". GA 12 [27], p. 24.

104 "Language", p. 200. Original: "Der Unter-Schied hält von sich her die Mitte auseinander, auf die zu und durch die hindurch Welt und Dinge zueinander einig sind. Die Innigkeit des UnterSchiedes ist das Einigende der diaphorá, des durchtragenden Austrags". GA 12 [25], p. 22.
} 
of beings. It concerns the seeing of the sacred in this intimate between. In the poem, Year (Jahr), Trakl says: "Golden eye"105. This golden seeing that might also be called holy see or be related to the seeing of the sacred concerns the gathering of that middle which grants things. To see this invisible unity is to let ourselves be touched by this pain.

Thus pain, the great soul's fundamental trait, remains pure harmony with the holiness (...). For [this] (...) shines upon the soul's face by withdrawing into its own depth. Whenever it is present, the holy endures only by keeping within this withdrawal, and by turning vision toward the fitting ${ }^{106}$.

The heart is also our own depth. To turn to this abyss is to turn toward the withdrawal of being. This abyss evokes the withdrawal of (the arrival of) the becoming man of God, that is: the withdrawal of the provenance of all being. "It [dif-ference] exists only as this single difference. It is unique"107. The golden eye is the "Golden eye of the beginning"108. The soul achieves its greatness through its capacity of beholding a flaming vision. "Spirit is flame. It glows and shines"109. Pain must serve this flame to truly be pain. "Its [the?] shining takes place in the beholding look. To such a vision is given the advent of all that shines, where all that is, is present. This flaming vision is pain" ${ }^{110}$. Pain evokes the intimacy of a shared seeing. The Pope's hand gestures are an invitation to the awareness of this unique shine, an invitation to let ourselves be touched by this pain. The Pope's golden mantle might be meaningful in this context, since this seeing transforms and cover us too with this bright golden. The openness to this shining concerns the openness to the gift of life. To get close to this shining it is to get close to its

\footnotetext{
105 "Language in the poem", p. 176. Original: "Goldenes Auge". GA 12 [56], p. 53.

106 "Language in the poem", p. 183. Original: "So bleibt der Schmerz als der Grundzug der großen Seele die reine Entsprechung zur Heiligkeit (...). Denn diese leuchtet dem Antlitz der Seele entgegen, indem sie sich in ihre eigene Tiefe entzieht. Das Heilige währt, wenn es west, je nur so, daß es in diesem Entzug verhält und das Anschauen in das Fügsame verweist".. GA 12 [65], p. 61. 107 "Language", p. 200. Original: "Der (...) Unter-Schied ist nur als dieser Eine. Er ist einzig". GA 12 [25], p. 22.

108 "Language in the poem, p. 176. Original: "Goldenes Auge des Anbeginns". GA 12 [56], p. 53.

109 "Language in the poem", p. 181. Original: "Der Geist ist Flamme. Glühend leuchtet sie". GA 12 [62], p. 58.

110 "Language in the poem", p. 181. Original: "Das Leuchten geschieht im Blick des Anschauens. Solchem Anschauen ereignet sich die Ankunft des Scheinenden, worin alles Wesende anwest. Dieses flammende Anschauen ist der Schmerz". GA 12 [62], p. 58.
} 
graces. "As pain, the spirit which bears the gift of the 'great soul' is the animator $\left.{ }^{111}\right]$. And the soul so gifted is the giver of life"112.

To dig into this pain is to shine harder. To go deeper is to fall to the sky. "If we let ourselves fall into the abyss (...), (...) We fall upward, to a height. Its loftiness opens up a depth" $" 113$. To bring again the reference to the tree is very enlighten in this context. It helps us to understand the intimacy between the abyss and the height. To flourish, the tree must take root into the earth. Going deeper, it goes higher. To ground itself into this abyss is to open itself to a golden blooming and to heaven's graces, which are the fruits of the tree.

Thus it [the tree] is sound and flourishes into a blooming that opens itself to heaven's blessing. The tree's towering has been called. It spans both the ecstasy of flowering and the soberness of the nourishing sap. The earth's abated growth and the sky's open bounty belong together. The poem names the tree of graces ${ }^{114}$.

Unless a seed fall upon the ground and opens itself to a transformation, it won't flourish. Only by deepening its roots into the ground, the seed may become a tree. One more of Mary's titles might puzzle us here. She is also called "House of gold", Domus aurea ${ }^{115}$. She is the temple of the gold. A flame dwells in her ${ }^{116}$. Only by opening herself to this flame, she can hold a flaming vision. But how does she get close to this flame? Once she gets detached from what is familiar, she can shelter the extra-ordinary. Only when we keep silent, we can truly hear. The sheltering requires a silent openness. The silence makes room for a hearing. Her

\footnotetext{
${ }^{111}$ Sallis reminds us that for Hegel "in the look of the Madonna there is spiritual animation [die geistige Beseelung]". (SALLIS, J. The look of things, p. 8.) Although Hegel understands spirit and animation in a different way, the same choice of words is a significant clue of what is going on in the Madonna. Heidegger interpretation of the "golden eye" tries to evoke the original naming force of those common terms.

112 Translation edited by the author. Original translation: "The spirit which bears the gift of the "great soul" is pain: pain is the animator. And the soul so gifted is the giver of life". Lgm in the poem. Way, p. 181. Original: "Der Geist, der »große Seele" gibt, ist als Schmerz das Beseelende. Die also begabte Seele aber ist das Belebende". GA 12 [62], p. 58.

113 "Language", p 189-190. Original: "Wenn wir uns in den Abgrund (...) fallen lassen, (...) Wir fallen in die Höhe. Deren Hoheit öffnet eine Tiefe". GA 12 [13], p. 11. In the first sentence context, the abyss is related to what the previous sentence of the text, "Language speaks", denotes. The play of words remains, despite the omission of the selection made for this text purposes.

114 "Language", p. 198. Original: "So gedeiht er in das Blühen, das sich dem Segen des Himmels öffnet. Das Ragen des Baumes ist gerufen. Es durchmißt zumal den Rausch des Erblühens und die Nüchternheit der nährenden Säfte. Verhaltenes Wachstum der Erde und die Spende des Himmels gehören zueinander. Das Gedicht nennt den Baum der Gnaden”. GA 12 [23], p. 21.

${ }^{115}$ See Litaniae Lauretanae.

${ }^{116} \mathrm{It}$ is important to have in mind that the interpretation suggested here is not the traditional and metaphysical one. Elucidations are going to be made further in the text.
} 
apartness evokes earth's measured growth in its intimacy with the sky's open bounty. It does not imply however a self-effacement (Selbstaufgabe ${ }^{117}$ ) or passivity. To empty herself is to open a region. "Apartness is active as pure spirit. It is the radiance of the blue reposing in the spirit's depth and flaming in greater stillness, the blue that kindles a stiller childhood into the gold of the first beginning"118. It is active as a decision that grants a new beginning measured with the blue.

Clarity [Helle] sheltered in the dark is blueness. 'Clear' [Hell] originally means clear sound [hallend], the sound that calls out of the shelter of stillness, and so becomes clear [sich lichtet]. Blueness resounds in its clarity, ringing. In its resounding clarity shines the blue's darkness ${ }^{119}$.

The blue evokes a gathering or the intimacy of an in-between. Again: to go deeper is to go higher. To go deeper into the dark is to go higher towards the clarity. This process opens a region. "One glimpses into the clearing [Lichtung]"120.

According to Heidegger, the gathering opens a site, which is the site of apartness. This is the region of ghostly ${ }^{121}$ twilight (Geistliche Dämmerung), where the evening slips away. It does not point however to a sort of annihilation. To enter the night, to lose oneself in the withdrawal of the extra-ordinary, is to die as to be apart. The seed breaks apart. The one who is apart is called to incline as the day declines. This inclination is "simply an inclination to make ready that descent by which the stranger (Fremdling) goes under into the beginning of his wandering" 122 . The stranger is the one who is apart, the one who touches the extra-ordinary. The stranger is the deceased as the one who is buried and yet lives.

\footnotetext{
${ }^{117}$ Sometimes it is referred as self-renunciation. It is related to a decision. It is active as a decision. This will be discussed later. See "privation" (Entäußerung). In: GA 65, p 28. Contributions to philosophy, p. 21.

118 "Language in the poem", p. 185 Original: "Die Abgeschiedenheit west als der lautere Geist. Sie ist das in seiner Tiefe ruhende, stiller flammende Scheinen der Bläue, die eine stillere Kindheit in das Goldene des Anbeginns entflammt". GA 12 [66], p. 62.

119 "Language in the poem", p. 165. Original: "Die ins Dunkel geborgene Helle ist die Bläue. Hell, d. h. hallend, ist ursprünglich der Ton, der aus dem Bergenden der Stille ruft und also sich lichtet. Die Bläue hallt in ihrer Helle, indem sie läutet. In ihrer hallenden Helle leuchtet das Dunkel der Bläue”. GA 12 [44], p. 40.

${ }^{120}$ My translation. Original: "er blickt in die Lichtung”. GA 55, p. 173.

121 The German word evokes spirit (Geist).

122 "Language in the poem", p. 172. Original: "einzig geneigt, jenen Untergang zu bereiten, durch den der Fremdling in den Beginn seiner Wanderschaft eingeht". GA 12 [52], p. 47-48.
} 
Buried in the ground, his grave, the dead may take root. The root, as the related to one's origins, refers to his home.

It might seem at first sight that there is an incoherence between being a stranger and finding one's homeland. "The soul [, something strange (ein Fremdes),] only seeks the earth; it does not flee from it" "123, which means that "it is always underway" 124 . The stranger wonder about its rootedness, about its being on earth. He is the one who is detached from the usual familiarity we have to things ${ }^{125}$. This experience of the uncanny lead us to the search of a ground, our home-ground, our home-land (Heimat). The descent of the taking root concerns both a decline and his provenience. By getting close to the ground, the stranger gets close to the beginning. By anticipating his death, he opens itself to a rebirth. He rises for a new beginning. The one who died too soon is shrouded in a childhood that preserves the primeval earliness ${ }^{126}$.

Leonardo Da Vinci, even if inspired by other paths, caught this with mastery in his work An Old Man and a Youth facing one another ${ }^{127}$. Made with red chalk on paper, the drawing shows an old man facing a youth. It is the old man that looks forward and the youth that looks backwards. This is a strange chronology, since we might expect that the youth would come first. Nevertheless, looking back, the youth sees the ancient, which we could interpret as being the ancient beginning. Looking toward the youth, the old man stares a new beginning ${ }^{128}$. The ancient brings with it the youth of all beginnings. Are both figures father and son?

\footnotetext{
123 "Language in the poem", p. 163. Original: "Die Seele sucht die Erde erst, flieht sie nicht". GA 12 [41], p. 37.

124 "Language in the poem", p. 163. Original: "bleibt sie das Unterwegs". GA 12 [41], p. 37.

125 "The soul, something strange on earth". Heim - home, dwelling place; heimlich - to be familiar [in an inauthentic way]; Unheimlich - uncanny, strangeness, not being at home; Heimat - [true] home-ground [authentic way of being at home].

${ }^{126}$ Heraclitus' fragment 26 says: "Man kindles a light for himself in the night-time, when he has died but is alive". In: BURNET, J. Early Greek Philosophy, p. 102. In Greek [full fragment]:

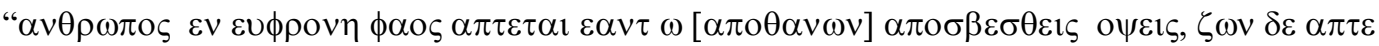

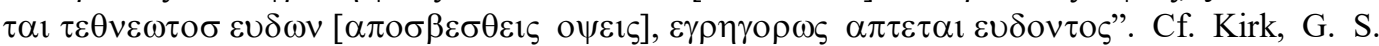
\& Raven, J. E. The presocratic philosophers, p. 207. "A man in the night kindles a light for himself when his vision is extinguished; living, he is in contact with the dead, when asleep, and with the sleeper, when awake".

127 See figure 2 on next page.

${ }^{128}$ See "The nature of language", p. 100. Heidegger quotes Hölderlin: "But those who serve the gods know / The earth well, and their step toward the abyss is / more human with youth. But that in the depths is old". The philosopher says that the poet's word appears in the region in which "earth and sky, the streaming of the deep and the might of the heights, encounter [ent-gegnen] one another". Original: "Diener der Himmlischen sind / Aber kundig der Erd, ihr Schritt ist gegen den Abgrund / Jugendlich menschlicher doch das in den Tiefen ist alt" and "die Erde und Himmel, das Strömen der Tiefe und die Macht der Höhe, einander ent-gegnen läßt”. GA 12 [207], 195.
} 


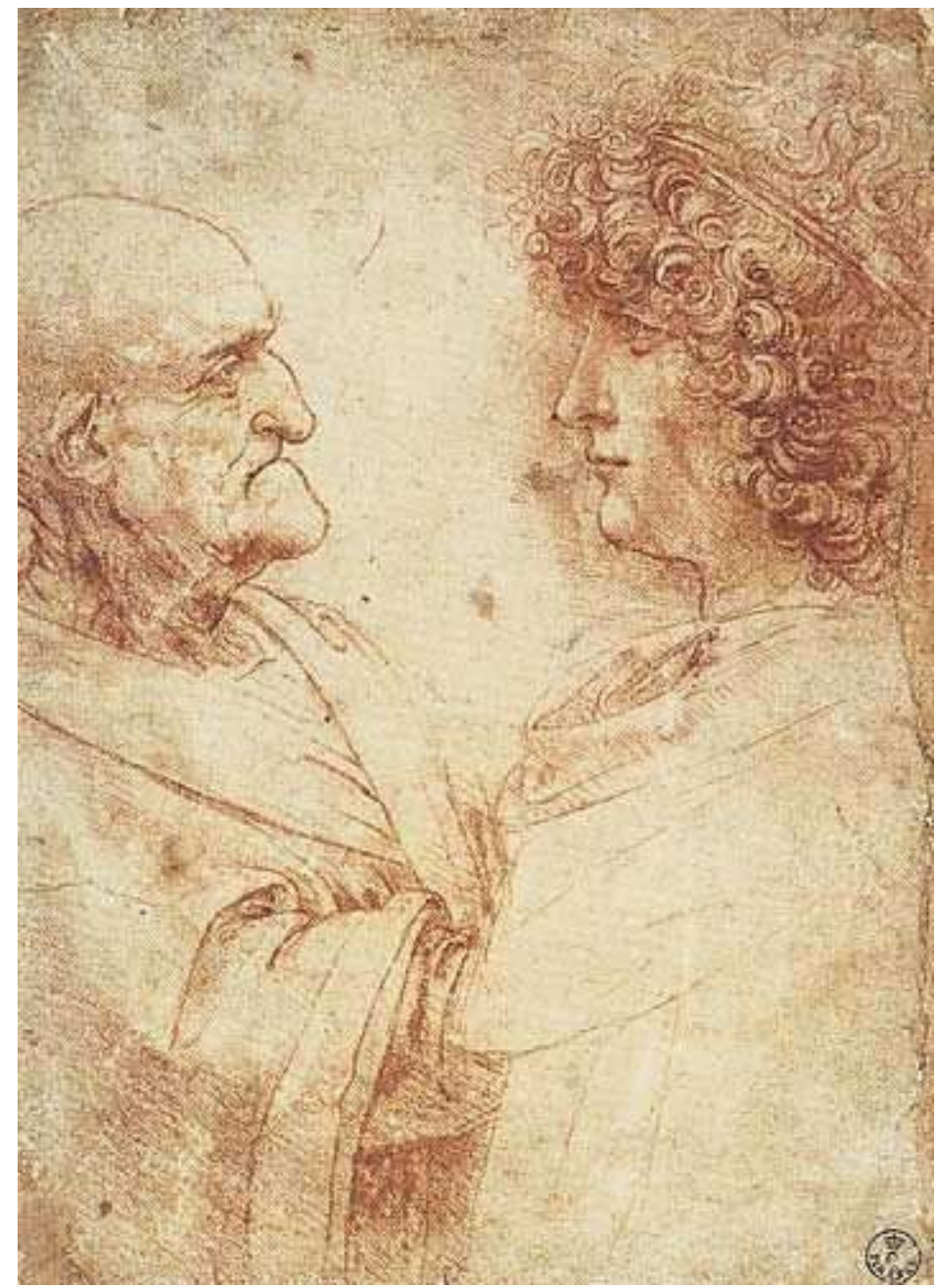

Figure 2

An Old Man and a Youth Facing One Another - Leonardo Da Vinci about $1500-1505$

Galleria degli Uffizi, Gabinetto dei Disegni e delle Stampe, Florence 
Or are they both Da Vinci himself in different times of his life? It seems not to be sure. In any case, their face to face reminds us of the face to face of the distant nearness of beginnings. It remainds us of the in-between of "the already dead and the unborn"129. It is the promise of the possibility of a rebirth. As Schuback synthetizes: "In-between the dead and the unborn is the hovering place of an isbeing, the event of existence" 130 .

According to Heidegger, "the terms 'something unborn' and 'something strange' say the same"131. The stranger is in touch with the concealment that, although never born in the sense of exhausted in appearing, is always at work in unconcealment, in the incessant rise. The dead is said to be also the unborn, since he is in touch with this primeval earliness that is the childhood of beginnings. The stiller childhood of the stranger is related, for Heidegger, not only to the prior beginning, but also to the possibility of other beginning tuned by a listening. The seed needs to die in a certain sense in order to give place to the tree. This only happens when it takes root in the earth. To take root means to investigate the ground of beings. To follow the path of beings' childhood is to tune ourselves with it. The forgottenness (Vergessenheit) of being is alienation of the search of a ground, of our home-land (Heimat) ${ }^{132}$. It "threatens our Bodenständigkeit, our 'root(ednes)s in the soil' "133. Our home-land evokes our hearts, what is deeply near us. "Man at the core [im Grunde] of his being has the capacity to think" ${ }^{134}$. What is in our innermost ${ }^{135}$ is at our core, our hearts. Man is then threatened at its core [im Innersten]"136. Man can be far from his home, be thoughtless, only because he has the capacity to think. Man's home-land is the meditative thinking (Das besinnliche Denken). "The way to what is near is always the longest and thus

\footnotetext{
${ }^{129}$ SCHUBACK, M. "The fiction of image", p. 79.

${ }^{130}$ SCHUBACK, M. "The fiction of image", p. 79.

131 "Language in the poem", p. 175. Original: "Die Namen »ein Ungeborenes« und »ein Fremdes« sagen dasselbe". GA 12 [55], p. 51.

${ }^{132}$ It means not being tuned by the search of a ground. To be attuned then is to be apart of the ordinary familiarity of things. The stranger is the one who is tuned by the uncanny and thus the one who is home-sick. This brings him to the path of the search of his home-ground, which is an $A b$-grund. So, the stranger is invited from an inauthentic relation to beings to an authentic one. It is also worth noticing that this attunement evokes the disclosure of the world. It is not a mere feeling, that is it is not something placed in the subject, but rather the being apart of the stranger evokes the view point of the one as a 'whole'.

${ }^{133}$ INWOOD, M. A Heidegger Dictionary, p. 117.

${ }^{134}$ MA, p. 45. Original: “der Mensch im Grunde seines Wesens die Fähigkeit zum Denken”. GA 16, p. 519.

${ }^{135}$ Or deep in the ground.

${ }^{136}$ MA, p. 49. GA 16, p. 522.
} 
the hardest for us humans. This way is the way of meditative thinking"137, which "demands of us that we engage ourselves with what at first sight does not go together at all"138. Meditative thinking "contemplates the meaning which reigns in everything that is" $" 139$.

To put ourselves on the path of this investigation is an active decision to think and open ourselves to the extra-ordinary. Thinking is "waiting 'for [auf]' the openness, which Heidegger now calls (die) Gegnet, the 'regioning', an old form of Gegend, 'region', which means 'free expanse'" 140 . According to Heidegger, "for a truly joyous and salutary human work to flourish, man must be able to mount from the depth of his home ground up into the ether. Ether here means the free air

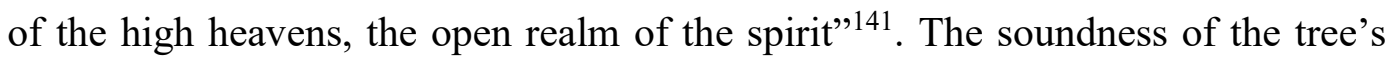
rising comes from being grounded, from the tree's digging into the depth of the ground. It does not mean however to have a founding ground. This ground is an Ab-grund, an abyss in the sense of a depth that refuses to provide a foundation. The ground's depth hides itself in the dark. Despite the lack of foundation, the withdrawal aspect of the ground is, as we mentioned, related to the falling to a height. That which hides itself in a refusal of foundation also approaches us. "That which shows itself and at the same time withdraws is the essential trait of what we call the mystery [Geheimnis]"142.

The openness to the mystery (Geheimnis) is openness to a hearing, openness to thinking as a hearing. To hear means to hear the measure. The heart as that which gives heed to the measure evokes the attention to a wideness, a

\footnotetext{
${ }^{137}$ MA, p. 53. Original: "Denn der Weg zum Nahen ist für uns Menschen jederzeit der weiteste und darum schwerste. Dieser Weg ist ein Weg des Nachdenkens". GA 16, p. 526.

${ }^{138}$ MA, p. 53. Original: "verlangt von uns, daß wir uns auf solches einlassen, was in sich dem ersten Anschein nach gar nicht zusammengeht". GA 16, p. 526.

${ }^{139}$ MA, p. 46. Original: "dem Sinn nachdenkt, der in allem waltet, was ist". GA 16, p. 520.

${ }^{140}$ INWOOD, M. A Heidegger Dictionary, p. 118.

${ }^{141}$ MA, p. 47-48. Original: "Wo ein wahrhaft freudiges und heilsames Menschenwerk gedeihen soll, muß der Mensch aus der Tiefe des heimatlichen Bodens in den Äther hinaufsteigen können. Äther bedeutet hier: die freie Luft des hohen Himmels, den offenen Bereich des Geistes". GA 16, p. 521 .

${ }_{142}$ It is important to pay attention to the relation between the German word for mystery, Geheimnis, and the German word for home, Heim, and for home-land, Heimat. MA, p. 55. Original: "Was auf solche Weise sich zeigt und zugleich sich entzieht, ist der Grundzug dessen, was wir das Geheimnis nennen". GA 16, p. 528.
} 
spaciousness, a region. According to Heidegger, "The fundamental meaning, that is, the essence of the $\mu \varepsilon^{\prime} \tau \rho o v$ is the wideness, the open, the clearing that extends and expands. (...) The incessant rise inflames the wide that essentially belongs to it, [and] which rises in it as rising"143. Thus, the openness to the mystery evokes the openness of the open, a wideness.

The first part of a section of Isaiah book called "the majesty of God" makes one wonder: "Who was it measured the water of the sea in the hollow of his hand and calculated the dimensions of the heavens, gauged the whole earth to the bushel, weighed the mountains in scales, the hills in a balance?"144. Heidegger understands doxa as the aspect in which something stands. If it is eminent, that is, harmonized with the measure, then doxa is brilliance and glory ${ }^{145}$.

In Hellenistic philosophy and in the New Testament, doxa theou, gloria Dei, is the majesty of God. To glorify, to bestow and demonstrate regard, is, in Greek, to place into the light and thereby to provide constancy, Being. Glory, for the Greeks, is not something additional that someone may or may not receive; it is the highest manner of Being ${ }^{146}$.

The philosopher believes that the Greek understanding of glory (Ruhm) helps to clarify how appearing belongs to Being ${ }^{147}$ or how "Being has its essence together with appearing" "148. According to him, doxa conveys to everything that appears (erscheint) or manifests (vor-scheint) itself. Something might, however, appear as "luster and glow" (Glanz und Leuchten) or as "mere seeming" (bloßen Schein), semblance $(\text { Anschein })^{149}$. An example he gives on this subject that might be interesting in the context of the Sistine Madonna is the halo of the saints.

\footnotetext{
${ }^{143}$ My translation. Original: "Die Grundbedeutung, d. h. das Wesen von $\mu \varepsilon \dot{\tau}$ คo v ist die Weite, das Offene, die sich erstreckende, weitende Lichtung. (...) Das immerdar Aufgehen entzündet sich die ihm wesenhaft eigenen, in ihm als Aufgehen aufgehenden Weiten". GA 55, p. 170.

${ }^{144}$ Isaiah, 40, 12.

${ }^{145}$ See IM [78].

${ }^{146}$ IM [78], p. 108. Original: "In der hellenistischen Theologie und im Neuen Testament ist dó $\xi \alpha$ $\theta \varepsilon o v ̛$, gloria Dei, die Herrlichkeit Gottes. Das Rühmen, Ansehen zuweisen und aufweisen, heißt griechisch: ins Licht stellen und damit Ständigkeit, Sein verschaffen. Ruhm ist für die Griechen nichts, was einer dazu bekommt oder nicht; er ist die Weise des höchsten Seins". GA 40 [78], p. 110.

${ }^{147}$ For a further development, see IM [75] and forward.

${ }^{148}$ IM [78]. Original: “das Sein im Erscheinen mit sein Wesen hat". GA 40 [78], p. 110.

149 See IM [76] for Heidegger's characterization of the three modes of Schein: Glanz und Leuchten; Erscheinen or Vorschein; and bloßen Schein or Anschein.
} 
From depictions of saints, we are familiar with the saint[']s halo $<$ Heiligenschein $>$, the radiant ring around the head. But we also know about false saints < Scheinheilige $>$, those who look like saints, but are not. (...) As the luster of the halo, the shining of the light makes the bearer manifest as a saint ${ }^{150}$.

For the Greeks, glory was the highest possibility of a human being. To achieve this meant to be sung by the poet. For Pindar, "glorifying constitutes the essence of poetry and is poetizing, and to poetize is to place into the light" ${ }^{151}$. As Hölderlin's words sing: “heaven's radiant height Crowns man, as blossoms crown the trees, with light"152. The heaven crowns men that have harmonized ${ }^{153}$ themselves with the measure. This harmonization would be the criteria for distinguishing an authentic appearing from an unauthentic appearing ${ }^{154}$. Heidegger calls attention to the relation between the seeing and the hearing involved in the glorifying aspect. The appearing in which someone stands "is experienced here mainly in terms of vision and visage, (...) [and] is grasped more in terms of hearing and calling $>$ Rufen < by other word for glory: kléos [, the repute]"155, as that which persists ${ }^{156}$. Glory is then intimately related to that which constantly persists. It is an unapparent shining in appearing, the unapparent shining of physis in appearing, that is, the unapparent shining of the incessant rise.

Among the Greeks, "beings were called phusis. This fundamental Greek word for beings is usually translated as 'nature.' We use the Latin translation

\footnotetext{
${ }^{150}$ IM [76], p. 104. Translation: "Wir kennen aus Darstellungen von Heiligen den Heiligenschein, den strahlenden Ring um das Haupt. Wir kennen aber auch Scheinheilige, solche, die aussehen wie Heilige, aber keine sind. (...) Der Lichterschein bringt als Glanz im Heiligenschein den, der ihn trägt, als Heiligen zum Vorschein”. GA 40 [76], p. 106-107.

${ }^{151}$ IM [78], p. 108. Original: "das Rühmen das Wesen der Dichtung ausmacht und Dichten ist: ins Licht stellen”. GA 40 [78], p. 110.

152 “...Poetically Man Dwells...”, p. 227. Original: “des Himmels Höhe glänzet / Den Menschen dann, wie Bäume Blüth' [Blüht'] umkränzet”. GA 7 [198], p. 208. Literally: "heaven's height shines then to man, as blossoms crown the trees".

${ }^{153}$ See: "l'homme auréolé, (...) 'c'est l'homme achevé, unifié par le haut' (...). On a pu dire des saints, en effet, qu'ils s'harmonisaient dans les hauteurs". CHEVALIER, J. \& GHEERBRANT, A. Dic. Symbole, p. 86. Translation: "the man with an halo, (...) it is the fulfilled man, unified by the height (...). We could, in fact, have said of the saints, that they have harmonized themselves within the heights".

${ }^{154}$ See figure 6 in the appendix. It shows two angels crowning the Sistine. It might be interesting to think possible relations between the loss of her crown and her displacement. (See also Benjamin discussions on the loss of a work's aura). It might be an issue the fact that these two upper angels with the crown are above the whole scene. They seem, however, to have been a latter Mannerist addition. See figure 8 in the appendix for a zoom on the reconstruction of the previous frame.

${ }^{155}$ IM [79], p. 109. Original: "hier mehr vom Sehen und Gesicht aus erfahren wird, das Ansehen,

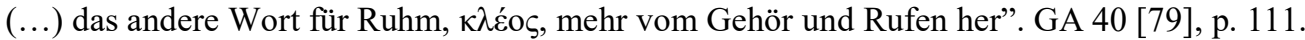

156 See the hymn Magnificat. It would be interesting to think the relation between the majesty of Mary as Queen, the Queen of Heaven, and its role as the one who makes room to hold the Heaven.
} 
natura, which really means 'to be born,' 'birth' "157. Heidegger argues that this translation forgets the originary naming force of the Greek and is the beginning of a distortion. According to him, Christianity has been influenced by this misleading interpretation. The Christian metaphysical understanding ignores the withdrawal aspect. The traditional metaphysical interpretation has focused on the physical side and has thought the possibility of a beyond. It happens because "This inception is taken as something that we have left behind long ago and supposedly overcome" 158 . This is the misunderstanding of a metaphysical reading of Christianity, for the German philosopher. The withdrawal aspect must be thought as inherent to unconcealment. Thus, remembered or not, concealment in its belonging together with unconcealment is always at work in the time-space play.

Heidegger also calls attention that our ordinary experience of the sun happens as it appearing to us as being smaller than the Earth. We might know that it is bigger. Nevertheless, it is not how we relate to it ordinarily. We see it as smaller. It is by ways of thinking that we dimension it as bigger.

Let us think about the sun. It rises and sets for us daily. Only a very few astronomers, physicists, and philosophers directly experience this fact otherwise, as the movement of the Earth around the sun-and even they do so only on the grounds of a particular, although rather widespread, conception. But the seeming [Schein] in which sun and Earth stand - for example, the early morning of a landscape, the sea in the evening, the night - is an appearing [Erscheinen]. This seeming [Schein] is not nothing. Neither is it untrue [un-wahr]. Neither is it a mere appearance of relations that in nature are really otherwise. This seeming [Schein] is historical and it is history, uncovered and grounded in poetry and saga, and thus an essential domain of our world $[\text { my highlights }]^{159}$.

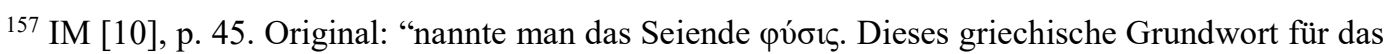
Seiende pflegt man mit »Na-tur« zu übersetzen. Man gebraucht die lateinische Ubersetzung natura, was eigentlich »geboren werden«, »Geburt« bedeutet". GA 40 [10], p. 15.

${ }^{158}$ IM [11], p. 15. Original: "Dieser Anfang gilt als solches, was die Heutigen als angeblich Überwundenes längst hinter sich gelassen haben". GA 40 [11], p. 16.

${ }^{159}$ IM [80], p. 110. Original: "Denken wir an die Sonne. Sie geht uns täglich auf und unter. Nur die wenigsten Astronomen, Physiker, Philosophen - und auch diese nur aufgrund einer besonderen, mehr oder minder geläufigen Einstellung - erfahren diesen Sachverhalt unmittel-bar anders, nämlich als Bewegung der Erde um die Sonne. Der Schein jedoch, in dem Sonne und Erde stehen, z. B. die Morgen-frühe der Landschaft, das Meer am Abend, die Nacht, ist ein Erscheinen. Dieser Schein ist nicht nichts. Er ist auch nicht un-wahr. Er ist auch keine bloße Erscheinung eigentlich anders gearteter Verhältnisse in der Natur. Dieser Schein ist geschicht-lich und Geschichte, entdeckt und gegründet in der Dichtung und Sage und so ein wesentlicher Bereich unserer Welt". GA 40 [80], p. 112.
} 
Even the astronomers, even the philosophers, do not experience it completely otherwise. Even they do not think yet on the grounds of a belonging together of concealment and unconcealment. Even they do not "experience" the 'it is', the factum est ${ }^{160}$. We are not supposed to run away from seeming, but to realize the intrinsic belonging of concealment and unconcealment in every appearing [Erscheinen], in everything that manifests itself.

Heidegger wants to criticize the modern interpretation of this way of appearing, seeming (Schein), as subjective. It presupposes that the subject is the center of reference and that he is the one who experiences. To approach appearing in terms of subject and object is a forgottenness of the way physis discloses itself. Physis names "what emerges from itself" 161 , that is: "This emerging and standingout-in-itself-from itself may not be taken as just one process among others that we observe in beings. Phusis is Being itself, by virtue of which beings first become and remain observable" ${ }^{\prime 62}$. It is physis itself in its rising that appears unapparently in glory. The "standing-in-itself means nothing other than standing there, standing-in-the-light" 163 .

Heidegger challenges: "Who can do both: the distant look into the most hidden essential sway of be-ing $\left[{ }^{164}\right]$ and the nearest prospering of the emerging shape of sheltering beings." 165 . Since it is physis itself that shines in glory, the way to harmonize ourselves with it in order to let it shine through us is opening ourselves to its presencing. The measure as the $\mu \dot{\varepsilon} \tau \rho o v$ is a regioning, so we too must make room. We undergo an experience. This means that "the experience is not of our own making"166. This is very important to stress in order to understand how even to the philosophers it might be too much. As moderns, "it strikes us only to the extent that for once it draws our attention to our relation to

\footnotetext{
${ }^{160}$ See OWA $\S 143$.

${ }^{161}$ IM [11], p. 15. Translation of: “das von sich aus Aufgehende”. GA 40 [11], p. 16.

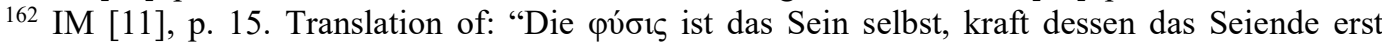
beobachtbar wird und bleibt". GA 40 [11], p. 17.

${ }^{163}$ IM [77], p. 107. Original: "Das Insichstehen (..) besagt (...) nichts anderes als Da-stehen, ImLicht-stehen”. GA 40 [77], p. 108.

${ }^{164}$ See INWOOD, M. A Heidegger dictionary p. 34, and p. 8: "a change of vocabulary does not automatically entail a change of thought".

165 From Enowning, p. 50. Original: "Wer Beides vermöchte: den fernsten Blick in das verborgenste Wesen des Seyns und das nächste Glücken der aufscheinenden Gestalt des bergenden Seienden”. GA 65, ['32], p. 72.

166 "The nature of language", p. 57. Original: "nicht (..) wir die Erfahrung durch uns bewerkstelligen”. GA 12 [159], p. 149.
} 
language"167. But it is more. If we let, it "transforms us"168. To undergo "means that we endure it, suffer it, receive it as it strikes us and submit to it. It is this something itself that comes about, comes to pass, happens"169.

It is Being as physis that appropriates itself in its disclosure. Making room, we let Being shine as brilliance, crown us with glory. The physis as incessant rise is associated by Heidegger to the flourishing as the blooming of a rose that unfolding opens itself up in appearance ${ }^{170}$. We must let our words unfold like flowers ${ }^{171}$, that is: from itself, from the source of its being. The shining and the blooming are intimate with each other. The flourishing comes to shine to the eye as arrival, an inceptual arrival. This arrival has the freshness of a beginning. "This is the earliness toward which (...) [the] golden countenance [Antlitz] is turned [entgegen blickt]. In its countering glance [Gegenblick], it keeps alive the nocturnal flame of the spirit of apartness [my highlights]" ${ }^{\prime 172}$. The nocturnal flame is said to be nocturnal because of its unapparent (and sheltering) character. The golden countenance (Antlitz) mirrors the gold that shines through everything that is. "In the way in which it flames, apartness itself is the spirit and thus the gathering power" 173 .

The sheltering of the gathering happens through the making room of apartness. The relation to a seeing in this sheltering is what grants the light crowning as the shining of the incessant rise. "Being is the fundamental

\footnotetext{
167 "The nature of language", p. 57. Original: "sie uns auch nur so weit trifft, daß wir erst einmal auf unser Verhältnis zur Sprache aufmerksam werden”. GA 12 [159], p. 149.

168 "The nature of language", p. 57. Original: "uns (...) verwandelt". GA 12 [159], p. 149.

169 "The nature of language", p. 57. Original: "heißt (...) durchmachen, erleiden, das uns Treffende vernehmend empfangen, annehmen, insofern wir uns ihm fügen. Es macht sich etwas, es schickt sich, es fügt sich”. GA 12 [159], p. 149.

${ }^{170}$ See IM [11]. It is worth mentioning that Mary is also called the Mystical Rose. We might think this title as referring to such silent blooming. 'Mystical' has its root in ' $m y$ ' that comes from the Greek verb 'myo', which means 'closure'. It is related to the meaning of 'closing the mouth', that is, to silence. This meaning has been related to the inaccessible character of what is at stake for those who have not experienced it. It is also interesting to notice that the mystical, as closure, is related in Mary's title to a rose, that is, to a blooming. We could link both to the mutual belonging of concealment and unconcealment.

${ }^{171}$ See "The nature of language", p. 100. GA 12 [207], p. 196. Heidegger is analyzing Hölderlin's verse " $>>$ Words, like flowers $<<$ " (")> Worte, wie Blumen $<<$ ").

172 "The nature of language", p. 185. Original: "Dieser Frühe entgegen blickt das goldene Antlitz (...). In ihrem Gegenblick wahrt sie die nächtliche Flamme des Geistes der Abgeschiedenheit". GA 12 [66], p. 62.

173 "The nature of language", p. 185. Original: "DieAbgeschiedenheit ist in der Art ihres Flammens selbst der Geist und als dieser das Versammelnde". GA 12 [66], p. 63.
} 
characteristic of the noble and nobility (that is, what has and rests upon high, essential provenance)"174. This essential provenance is such golden.

Already in ancient Greece poets and thinkers touched on this mystery [Geheimnis]. The illumination [Helle] which grants every present being its presence manifests its gathered, suddenly appearing dominance in lightning.

(...) the lightning brings and directs the appearance of the formation of the initself-present by a single strike. The lightning is thrown by Zeus, the supreme God. And what of Athena? She is the daughter of Zeus.

(...) Aeschylus presents Athena (...) saying:

'Of all the Gods I [Athena] am the only one [ $\left.{ }^{175}\right]$ who knows the key to the house wherein the lightning bolt rests in its seal.' [my highlights] ${ }^{176}$.

Despite the singularity of each case, it is interesting to notice that Athena "knows the key" to the house of lightning and to recall that one of Mary's titles is house of gold. It is also worth mentioning that, as Athena is the daughter of Zeus, we can also say that Mary is the daughter of God. Heidegger would probably say that a world separates them, since Mary is merged in the metaphysical interpretations associated to Christianity. But, since Heidegger seems to gesture to an originary interpretation of Raphael's canvas, how could we find the naming force of this distant nearness? How could we let this dwelling speak to us? How could we hear it?

The originary Bild, says Heidegger, involves a step back. Let's remember the key quote from Language and homeland (Sprache und Heimat) referred to in the introduction. It traces the originary meaning of Bild with the aid of the

\footnotetext{
${ }^{174}$ IM [77], p. 106. Original: "Das Sein ist die Grundbestimmung des Edlen und des Adels (d. h. dessen, was eine hohe Wesensherkunft hat und in ihr ruht)". GA 40 [77], p. 108.

${ }^{175}$ I wonder if it means that only through her, through this path of making room, it is possible to become house of the lighting. It might also be related to the purest way in which it happens in her. There are several references in Heidegger where he relates this shine to a character of purity. See, for example, GA 55, p. 143, 144, 162, 163. The passage "Das Edle des reinen Aufgehens", "The nobility of pure rising" (my translation), points to the intimacy between the crowing and the rising in its purity. I believe that the purity is related to the unnaparent (unscheinbaren) character (See GA 55, p. 143), since this shine is a shining through, a translucence. To have "more purity" would mean then to let it shine through even harder, since the purity concerns the incessant rise and not ourselves or ourselves only in a derivative way.

176 The provenance of art, p. 121-122. Original: "Schon im frühen Griechentum haben zwar Dichter und Denker an dieses Geheimnis gerührt. Die Helle, die allem Anwesenden seine Anwesenheit gewährt, zeigt ihr gesammeltes, jäh sich bekundendes Walten im Blitz. / (...) Der Blitz bringt und lenkt das Erscheinen des von sich her in seinem Gepräge Anwesenden mit einem Schlag. Den Blitz schleudert Zeus, der oberste Gott. Und Athene? Sie ist die Tochter des Zeus. / (...) läßt (...) Aischylos (...) Athene sprechen: / (...) 'Von den Göttern ich allein nur weiß den Schlüssel zu dem Haus, darin der Blitz versiegelt eingeschlossen ruht' ". GA 80. In: http://www.eudia.org/wp/download.php?id=1142, p. 6-7.
} 
meaning of icon, which "has (...) a deeper meaning coming from the verb $\varepsilon \iota \kappa \omega$, that is, to stand back before, to step back before something and then let that before which one stands back arrive - and thus appear [my highlights]"177. We seem to have elements by now to say that this before which we step back before is the incessant rise of physis. Standing back, we let it appear in its shining and thus we may become houses of gold ${ }^{178}$. The Bild as a bringing into emergence (her-vorbringen), as Heidegger characterizes it, is the bringing into emergence of this shine, a step back that lets this shine emerge.

According to Heidegger,

To form [, to constitute] [Bilden] is to bring forth here [ ${ }^{179}$ ] [to bring into emergence, pro-duct] [her-vor-bringen], namely, f o r t h $\mathbf{h}\left[\begin{array}{ll}\boldsymbol{v} & \boldsymbol{r}\end{array}\right]$ in unconcealment [das Unverborgene], into manifestation [Offenbare] and $\mathbf{h} \mathbf{e} \mathbf{r} \mathbf{e}\left[\mathbf{h} \mathbf{e}{ }^{180}\right]$ [emerged] from the concealed and self-concealing. That so understood brought forth here, formed [constituted] [Gebildete] is the formation [constitution] [the image formed] [das Gebild] [ ${ }^{181}$ ]. Insofar as this comes to manifest [Vorschein] and, therefore, comes into appearing [Scheinen], it offers itself to a sight, and, as formation [constitution] [Gebild], it is, at the same time, originary image [Bild]. (...) The image [Bild] originarily belongs to the formation [Gebild] as a bringing forth here [her-vor-bringung] [a pro-duction], not the other way around [my highlights ${ }^{182}$.

The copy and the reproduction do not bring into emergence in the same way as the Bild, that is: originarily. They do not bring forth the incessant rise in its brilliance. They, "copies and imitations[,] are already mere variations on the genuine image

\footnotetext{
177 My translation of: "hat (...) einen tieferen Sinn, herkommend vom Zeitwort $\varepsilon 1 \kappa \omega$, d. h. zurückweichen vor, zurücktreten vor etwas und so dieses Wovor auf sich zukommen - und damit erscheinen - lassen". GA 13, p. 171.

${ }^{178}$ The icon used to be called image relic (icona). See Belting, Likeness and presence.

${ }^{179}$ See KLUGE, 'her', p. 144, and Experiencias del pensar, p. 118. The Spanish translation is attentive to the aspect that the bringing forth happens here (in time-space).

180 The English translation of other passage which also plays with this word, namely, 'hervorbringen', uses 'hither' as correspondent to 'her'. See GA 7 [154] and "Building Dwelling Thinking" (in Basic Writings, p. 361, and in PLT, p. 157).

${ }^{181}$ Heidegger is playing here with the possible meanings of Gebild, which might refer to a 'thing' as what has been constituted, as much as to a 'shape', 'construction' or 'formation' as the constitution of a thing. The Spanish translation uses 'configuración'. See Hofstadter translation in The thinker as poet, p. 7 (In: PLT). He suggests "image formed" as the correspondent to Gebild. See also MUGERAUER, R. Heidegger and Homecomig, p. 580. He uses 'formation' as translation to Gebild.

${ }^{182}$ My translation. Original: "Bilden ist Her-vor-bringen, nämlich v o $\mathrm{r}$ ins Unverborgene, Offenbare und $\mathrm{h}$ e $\mathrm{r}$ aus dem Verborgenen und Sichverbergenden. Das so verstandene Hervorgebrachte, Gebildete ist das Gebild. Insofern dieses zum Vorschein und damit ins Scheinen kommt, bietet es einen Anblick und ist als Gebild zugleich das ursprüngliche Bild. (...) Bild gehört ursprünglich ins Gebild als Hervorbringung, nicht umgekehrt”. GA 13, p. 171.
} 
which, as a sight or spectacle, lets the invisible be seen and so imagines the invisible in something alien to it" ${ }^{\prime 183}$, that is: make the extraordinary inapparently appear in the ordinary. Copies are, then, related to this bringing into emergence, to the Bild, only in a derivative way.

The same happens with saying. It is not every saying that is poetic. The saying that is poetic let the incessant rise shine. That's why poetry "speaks in images [Bildern]" ${ }^{\prime 184}$. In The Thinker as Poet, we can read:

The splendor $\left[{ }^{185}\right]$ of the simple [Schlichten].

Only image formed [Gebild] [safe]keeps the vision [Gesicht, face, sight].

Yet image formed [Gebild] rests in the poem ${ }^{186}$.

In Language and homeland (Sprache und Heimat), Heidegger explains that, because the poetic essence has always already been seen [gesichtet], even if not specifically looked at ${ }^{187}$, it "shall be called the $\mathrm{sight}$ [d as Gesicht, the face $^{188}$ ] par excellence" 189 . Heidegger's play of words addresses again the unapparent appearing as always available in unconcealment, even if not grasped as incessant rise. What we have always already looked is the look, what we have always already faced is the face. In this sense, it is worth paying attention to the

183 “...Poetically Man Dwells...", p. 223. Original: "sind die Abbilder und Nachbilder bereits Abarten des eigentlichen Bildes, das als Anblick das Unsichtbare sehen läßt und es so in ein ihm Fremdes einbildet". GA7 [194], p. 204.

${ }^{184}$ My translation. Original: “die Dichtung in Bildern spricht”. GA 13, p. 172.

185 In Splendeur divine, Vernant says that "splendor and radiance of the divine" ("splendeur, rayonnement du divine") might be related, for exemple, to pulhuhtu, which has acquired in some instances "a sense close to oneself [soi-même]" ("un sens proche de $<<$ soi-même $>>$ "), or to melammu, which concerns "a concret, (...), [concealed,] perhaps masked object" ("un object concret, (...) voire masque"). In: VERNANT, J. "Splendeur divine", p. 518-519.

186 "The Thinker as Poet", p. 7. Original: "Die Pracht des Schlichten. / Erst Gebild wahrt Gesicht. / Doch Gebild ruht im Gedicht". GA 13, p. 79. These two final verses are quoted by Heidegger in Sprache und Heimat, p. 180. He makes an addition to the first of them: "Erst Gebild wahrt (d.h. verwahrt) [that is safekeep] Gesicht".

${ }^{187}$ See IM [1], p. 1. "Many never run into this question at all, if running into the question means not only hearing and reading the interrogative sentence as uttered, but asking the question, that is, taking a stand on it, posing it, compelling oneself into the state of this questioning. / And yet, we are each touched once, maybe even now and then, by the concealed power of this question, without properly grasping what is happening to us". Original: "Viele stoßen überhaupt nie auf diese Frage, wenn das heißen soll, nicht nur den Fragesatz als ausgesagten hören und lesen, sondern: die Frage fragen, d. h. sie zustandbringen, sie stellen, sich in den Zustand dieses Fragens nötigen. / Und dennoch! Jeder wird einmal, vielleicht sogar dann und wann, von der verborgenen Macht dieser Frage gestreift, ohne recht zu fassen, was ihm geschieht". GA 40 [1], p. 3.

188 The Spanish translation uses 'el rostro'. See Experiencias del pensar, p. 128. In English, it would sound like: what has always already been faced "shall be called the face".

${ }^{189}$ My translation. Original: “d a s G e s i c h t schlechthin genannt warden darf”. GA 13, p. 180. 
clouds made of angel faces all around the Madonna with the Child and behind the curtains. We might interpret them as related to this unapparent sight, face, of the constitution of things.

Poetry recites to our ears ${ }^{190}$ [ $V$ o r sagen], to our hearing. It speaks as "promise" [z u sagen $]^{191}$. In the Bible, we read: " "Why do you talk to them in parables?' $\left[{ }^{192}\right]$ (...) The reason I talk to them in parables is that they look without seeing and listen without hearing or understanding"193. This passage admits an interpretation in correspondence with the previous remarks in which that which appears or is brought into emergence in poetry although looked is not seen and that which is sung in poetry is not heard. Again, it would be a way of mirroring the unfolding structure of the truth as alétheia, as an unfolding of the mutual belonging of concealment and unconcealment.

The inherence of the concealment aspect is addressed by Heidegger in the following words:

\begin{abstract}
The default of God and the divinities is absence. But absence is not nothing; rather it is precisely the presence, which must first be appropriated, of the hidden fullness and wealth of what has been and what, thus gathered, is presencing, of the divine in the world of the Greeks, in prophetic Judaism, in the preaching of Jesus. This nolonger is in itself a not-yet of the veiled arrival of its inexhaustible nature [my highlights] ${ }^{194}$.
\end{abstract}

The 'not-yet' is the waiting for appropriation of what is always already presencing. It is the waiting for a new beginning as a shine in glory. The appearing among beings and at, the same time, the intimacy with the hidden fullness are gathered in divinities. This unifying gathering "wants and does not want" ${ }^{195}$, Heraclitus would say, to be called Zeus, or, I add, God, or by the name of another deity. According to Heidegger, the unifying gathering does not allow to

\footnotetext{
${ }^{190}$ See GA 13, Sprache und Heimat, p. 171.

${ }^{191}$ See GA 13, Sprache und Heimat, p. 171.

${ }^{192}$ See Mt 13, 35: "I will speak to you in parables and expound things hidden since the foundation of the world". See also the epigraph used in the introduction of this dissertation.

${ }^{193}$ Mt 13, 10-14.

194 "Epilogue" in "The Thing", p. 182. Original: "Der Fehl Gottes und des Göttlichen ist Abwesenheit. Allein, Abwesenheit ist nicht nichts, sondern sie ist die gerade erst anzueignende Anwesenheit" der verborgenen Fülle des Gewesenen und so versammelt Wesenden, des Göttlichen im Griechentum, im Prophetisch-Jüdischen, in der Predigt Jesu. Dieses Nicht-mehr ist in sich ein Noch-nicht der verhüllten Ankunft seines unausschöpfbaren Wesens". GA 7 [177], p. 185.

${ }^{195}$ See Heidegger's discussion of this reference to Heraclitus (frag. 32 or B52) in GA 7 [214] ff. (a translation is available in Early Greek Thinking, p. 72 ff.).
} 
be called by the name of a divinity because it "does not exist as one being" Nevertheless, it admits being called Zeus, for example, once in he "the totality of present beings is under its highest aspect" 197 : I would say: gathered in glorious shine, majesty.

Schuback caught this nuance, when she says:

Thus what bewitches so called 'primitive people' is not that they do not see the difference between the image of an ancestor and the ancestor himself but precisely the contrary, namely, that they do see how the image of the ancestor is the ancestor precisely by being his image and hence by not being the ancestor in body and flesh $^{198}$.

This impossibility of exhausting the concealment in unconcealment is addressed by Heidegger, still in Language and homeland (Sprache und Heimat), when he discusses Hebel's poem called The Summer's twilight (Der Sommerabend) ${ }^{199}$. He calls attention to two verses, in Old High German, that recite: "It is truth" ['s isch wohr], "it is all truth" ['s isch weger wohr $]^{200}$. According to him, "It is true" ['s isch wohr], means "openly appears", it is manifest ${ }^{201}$. The augmentative "weger" comes from "truth" (wahr), thus, "weger wohr" is the evidently manifest. It has an ancient use character ${ }^{202}$. Heidegger interprets Hebel use of "it is all true" as related to that which, although evidently manifest, is not completely grasped, that is: it remains a mystery (Geheimnis). For Heidegger, the mysterious is the astonishing (Erstaunliche). A thing is something "full of mystery", that is: although evidently manifest, it is not completely grasped. Heidegger's relates the mystery (Geheimnis) to the being "a thing" [e Sach]. The ambiguity is also at

196 “Logos (Heraklit, fragment B 50)", p. 74. Original: “eines Anwesenden unter anderem”. GA 7 [216], p. 229.

197 "Logos (Heraklit, fragment B 50)", p. 74. Original: "Das Ganze des Anwesenden ist unter seinem Höchsten”. GA 7 [216], p. 229.

198 SCHUBACK, M. "The fiction of image", p. 71.

${ }^{199}$ I would like to call attention to the relation between this poem from Hebel and A Winter's twilight (Ein Winterabend) poem from Trakl, which has been previously mentioned. (Hebel's poem is usually referred to as "A Sommer evening". I prefer twilight not only because of the transition that is being described in the poem, but also because it has a connotation that mix light and shadow.

${ }^{200}$ GA 13, Sprache und Heimat, p. 168.

${ }^{201}$ GA 13, Sprache und Heimat, p. 168.

${ }^{202}$ We find such expression also used in the Bible, for example. See John 3, 3: "In all truth I tell you". It comes from "amen, amen", which seems to be related to loyalty or fidelity to the truth, that is: to that which is faithful to truth. I would say that it is kind of a way of echoing truth. Augustine's sermon 272 says about Eucharistic: "[W] hat you receive is the mystery that means you. It is to what you are that you reply Amen, and by so replying you express your assent. [...] [R] eceive what you are". (In: Apud KEENAN, D. The question of sacrifice, p. 174.) 
work in the quote previously mentioned on the definition of Bilden. Gebild might mean a thing, an image formed, constituted, as much as the constitution of a thing. As something constituted, it is evidently manifest, but its constitution remains not completely grasped.

All appearing belongs to the incessant rise, be it authentically or inauthentically. Heidegger defends that the poem is not referring to a thing whatsoever, but to a particular one, one full of mystery. We might say: an originary one, an authentic one in which the shine appears in its brilliance.

The poet makes poetry only when he takes the measure, by saying the sights of heaven in such a way that he submits to its appearances as to the alien element to which the unknown god has 'yielded.' Our current name for the sight and appearance of something is 'image.' [Bild] The nature of the image [des Bildes] is to let something be seen ${ }^{203}$.

For Heidegger, the godhead is the measure, once it appears as remaining unknown. "The measure consists in the way in which the god who remains unknown, is revealed as such by the sky"204. The mysterious is "not only God himself”, but its “manifestness (Offenbarkeit)" "205.

The poetic saying of images gathers the brightness and sound of the heavenly appearances into one with the darkness and silence of what is alien [strange]. By such sights the god surprises us. In this strangeness he proclaims his unfaltering nearness ${ }^{206}$.

Nearness [Nähe], says Heidegger, "is what paves the way for being face-to-face [Gegen-einander-über]"207.

203 “...Poetically Man Dwells...”, p. 223. Original: "Der Dichter dichtet nur dann, wenn er das $\mathrm{Ma} ß$ nimmt, indem er die Anblicke des Himmels so sagt, daß er sich seinen Erscheinungen als dem Fremden fügt, worein der unbekannte Gott sich »schiket«. Der uns geläufige Name für Anblick und Aussehen von etwas lautet »Bild«. Das Wesen des Bildes ist: etwas sehen zu lassen”. GA 7 [194], p. 204.

204 “...Poetically Man Dwells...", p. 220. Original: "Das Maß besteht in der Weise, wie der unbekannt bleibende Gott als dieser durch den Himmel offenbar ist". GA [192], p. 201.

205 “...Poetically Man Dwells...”, p. 220. Original: "nicht erst Er selbst”. GA 7 [191], p. 201.

206 “...Poetically Man Dwells...", p. 223-224. Original: "Das dichtende Sagen der Bilder versammelt Helle und Hall der Himmelserscheinungen in Eines mit dem Dunkel und dem Schweigen des Fremden. Durch solche Anblicke befremdet der Gott. In der Befremdung bekundet er seine unablässige Nähe". GA 7 [195], p. 205.

207 "The nature of language", p. 104. Original: "ist das Be-wëgen des Gegen-einander-über". GA 12 [211], p. 199. 


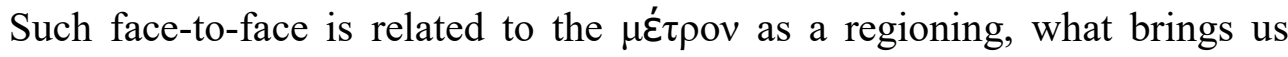
back to the character of being a house of gold. Heidegger states that "being faceto-face with one another has a more distant origin: it originates in that distance where earth and sky, the god and man reach one another"208. One of the most famous Marian hymns is called the Magnificat. Magnify is to intensify, making glorious. Once Mary opens herself to the mystery, she releases herself toward things. Let's remember that, for Heidegger, the mystery is the mutual belonging of concealment and unconcealment and that it happens in a thing or in things as a thing (Gebild), as a gathering of the ownmost constitution in something constituted. To release herself toward things means then to release herself toward the ownmost of things. According to Heidegger, "Releasement toward things and openness to the mystery belong together" ${ }^{209}$. Releasing herself to the ownmost of things, she makes room to hold the heaven in her womb. She lets the ownmost of things act in her. Such Mary's apartness belongs to a wideness, once "as a gathering, apartness is in the nature of a site [des Ortes]" ${ }^{, 10}$. The shining of the gathering through her of the ownmost of things makes her a site, a house of gold.

Athena as well rests her glance on the incessant rise of physis, on "that which arises from out of itself into its respective limit and here comes to dwell"211. Athena is known as the $\sigma \kappa \varepsilon \pi \tau$ o $\mu \varepsilon v \eta$, "the meditating one", the one who meditates on the limit. She turns her glance to the limit as "that on account of which something is gathered in its ownmost constitution, so that through it, it can appear in its fullness, it can come to presence [hervorzukommen]"212. Heidegger understands techne, not as a making, but rather as a form of knowing, one that brings forth Being in appearing. Because Athena's glance is turned toward Being as an incessant rise, she has "in view, in advance, that which is at stake in the

\footnotetext{
${ }^{208}$ GA 12. The nature of language, p. 104.

${ }^{209}$ MA, p. 55. GA 16, p. 528. Original: "Die Gelassenheit zu den Dingen und die Offenheit für das Geheimnis gehören zusammen".

210 "Laguage in the poem", p. 185. Original: "Als Versammlung hat die Abgeschiedenheit das Wesen des Ortes". GA 12 [67], p. 63.

211 "The provenance of art and the destination of thought", p. 121. Original: "das von sich her in seine jeweilige Grenze Aufgehende und darin Verweilende". GA $80 . \quad$ In: http://www.eudia.org/wp/download.php?id=1142, p. 5.

212 "The provenance of art and the destination of thought", p. 120-121. Original: "jenes, wodurch etwas in sein Eigenes versammelt ist, um daraus in seiner Fülle zu erscheinen, in die Anwesenheit hervorzukommen". GA 80. In: http://www.eudia.org/wp/download.php?id=1142, p. 5.
} 
production of a structure [Gebilde] of a work" ${ }^{213}$. Because her glance is turned toward Being and Being is what is brought forth in art as techne, that's why she can view ahead, premeditate: "this knowing views ahead toward that which reveals the form and gives the measure [my highlight]"214. This requires "a singular vision and clarity" 215 . This clear vision is what make of her a house of gold.

The Magnificat is also known as the Canticle of Mary or the Song of Mary $^{216}$. What authentically sings is poetry, which is also an art, a techne. "In poetry there takes place [ereignet sich] what all measuring is in the ground of its being"217. Measuring is "taking the measure (das Nehmen des Maßes)"218. This means that the fundamental act (Grundakt) of measuring is enowning (Ereignis). Opening herself, Mary lets the enowning happen, the ownmost of things appropriates itself. As a disclosure of appropriation (Ereignis), measuring appropriates itself in what it intrinsically is: an incessant rise that opens a region. "Measure-taking [Vermessen] gauges the between, which brings the two, heaven and earth, to one another" 219 .

It is important to stress, however, that this measure as a dimension "does not arise from the fact that sky and earth are turned toward one another. Rather, their facing each other itself depends on the dimension. Nor is the dimension a stretch of space as ordinarily understood" ${ }^{\text {220 }}$. According to Heidegger,

\footnotetext{
213 "The provenance of art and the destination of thought", p. 120. Original: "Jenes zuvor im Blick (...) [haben], worauf es im Hervorbringen eines Gebildes und Werkes ankommt". GA 80. In: http://www.eudia.org/wp/download.php?id=1142, p. 3

214 "The provenance of art and the destination of thought", p. 120. Original: "solches Wissen vorblickt in das Gestalt-weisende, Maßgebende". GA $80 . \quad$ In: http://www.eudia.org/wp/download.php?id=1142, p. 3

215 "The provenance of art and the destination of thought", p. 120. Original: "eine ausgezeichnete Weise der Sicht und der Helle". GA 80. In: http://www.eudia.org/wp/download.php?id=1142, p. 4. ${ }^{216}$ Heidegger adds: "Is apartness not one single silence of stillness? How can it start a saying and a singing on its way?". By keeping silent, we can truly hear and then truly say, that is: sing. In: "Language in the poem", p. 186. Original: "Ist die Abgeschiedenheit nicht ein einziges Schweigen der Stille? Wie kann die Abgeschiedenheit ein Sagen und Singen auf den Weg bringen?”. GA 12 [67], p. 63.

217 “...Poetically Man Dwells...”, p. 219. Original: "Im Dichten ereignet sich, was alles Messen im Grunde seines Wesens ist". GA 7 [190], p. 200.

218 “...Poetically Man Dwells...”, p. 219. GA 7 [190], p. 200.

219 “...Poetically Man Dwells...”, p. 219. Original: "Das Vermessen ermißt das Zwischen, das beide, Himmel und Erde, einander zubringt". GA 7 [190], p. 199.

220 “...Poetically Man Dwells...”, p. 218. Original: "die das Zwischen von Himmel und Erde offen ist (...). Sie entsteht nicht dadurch, daß Himmel und Erde einander zugekehrt sind. Die Zukehr beruht vielmehr ihrerseits in der Dimension. Diese ist auch keine Erstreckung des gewöhnlich vorgestellten Raumes". GA 7 [189], p. 198-199.
} 
No space could grant to things their place and arrangement, no time could temporalize [zeitigen] the hour or the year to becoming and perishing, that is, grant them their extension and duration, if the openness that by its sheer force traverses them had not always already been accorded to space and to time and to their mutual belonging ${ }^{221}$.

The dimension as the measure is what penetrates everything. "This 'on' and 'beneath' belong together. Their interplay is the span that man traverses at every moment" 222 . Because concealment comes together with unconcealment in a thing, things are. Because things are, as a concealment that comes together with unconcealment, things can face one another. Because things face one another, as a concealment that comes together with unconcealment, we can see the unapparent in what appears. Because we are the possibility of this authentic seeing of the mutual belonging of concealment and unconcealment, the ownmost of things can appropriate itself through us. As Hölderlin dictates: "For everything is concentrated upon the spiritual"223, which means, in Heidegger's words: "a gathering (...) is enowned as the gathering upon the relationship of be-ing $\left[{ }^{224}\right]$ to our ownmost, a relationship that is the center, the midpoint, that is everywhere as the midpoint of a circle whose periphery is nowhere" 225 .

In a passage of the Magnificat, Mary says: "My soul proclaims the greatness of the Lord (...) because he has looked upon his lowly handmaid"226. Lowly means to have a humble nature, to be ordinary ${ }^{227}$. By proclaiming herself as not distinct, Mary acknowledges her belonging to the whole. Bowing, she

\footnotetext{
${ }^{221}$ The provenance of art, p. 127. Original: "Kein Raum könnte den Dingen ihren Ort und ihre Zuordnung einräumen, keine Zeit könnte dem Werden und Vergehen Stunde und Jahr, d.h. Erstreckung und Dauer zeitigen, wäre nicht dem Raum und der Zeit, wäre nicht ihrem Zusammengehören schon die sie durchwaltende Offenheit verliehen". GA 80. In: http://www.eudia.org/wp/download.php?id=1142, p. 18.

222 “...Poetically Man Dwells...”,p. 221. Original: "Dieses »auf« und dieses »unter« gehören zusammen. Ihr Ineinander ist die Durchmessung, die der Mensch jederzeit durchgeht". GA 7 [192], p. 202.

${ }^{223}$ HÖLDERLIN Apud "Poverty", p. 6. Original: ">> Es koncentrirt sich bei uns alles auf"s Geistige. $<<"$. GA 73, p. 877.

${ }^{224}$ Heidegger specifies this use as referring to "that which in first place lets all beings be be-ings (Seyendes) and thus shelteringly encloses and surrounds them. We call it be-ing (das Seyn)". In: "Poverty", p. 6. Original: "das, was alles Seiende erst ein Seyendes sein läßt und es darum umhegt und umgibt. Wir nennen es das Seyn". GA 73, p. 877.

225 "Poverty", p. 6. Original: "eine Versammlung auf die Beziehung des Seyns zu unserem Wesen, welche Beziehung das Centrum ist, die Mitte, die überall ist als Mitte eines Kreises, dessen Peripherie nirgends ist". GA 73, p. 877.

${ }^{226}$ Luke 1, 47-49.

${ }^{227}$ To be humble, modest is not to be arrogant, full of yourself, full of ego. To be humble is to not affirm yourself as distinct, but to acknowledge your belonging to the whole.
} 
disconcertingly distinguishes herself. She holds a glorious shine. Recognizing her poverty, she becomes rich. As Heidegger says: "Becoming rich does not follow from be-ing poor like and effect following the cause. Rather, the genuinely [eigentliche] being poor is in itself be-ing rich [my highlights]"228. Inwood elucidates that Heidegger connects eigentlich, authentic, with eigen, own, "something of its own (zueigen)". Authentic "comes from the Greek autos, 'self, etc' and originally meant 'done by one's hand' "229.

Junito Brandão traces an interesting relation between the ground and humility. He refers to the latter as the "humility, that etymologically is linked to humus, 'ground', from which the homo, 'man', that is equally rooted from humus, was shaped"230. It is worth bringing back here the image of the tree that needs to go deeper into the ground in order to rise to the sky in a golden blooming. It is needed to dig into one's own nature in order to shine in brilliance. "We are poor, only when everything for us is concentrated on the spiritual"231. The Canticle of Mary says that "the Lord (...) looked upon his lowly handmaid". This means that He looked upon the ordinary as the unconcealment of concealment, as the mutual belonging of both, which is the ownmost of things, which is His gesture. Looking upon the ordinary as his gesture, he looks upon himself. This enowning as "the concentration on the spiritual means being gathered in the relation of be-ing to man and as gathered residing in it" ${ }^{232}$.

Heidegger addresses the craft of the hand in What is called thinking? He says:

The craft of the hand is richer than we commonly imagine. (...) The hand reaches and extends, receives and welcomes - and not just things: the hand extends itself, and receives its own welcome in the hands of others. The hand holds. The hand carries. The hand designs and signs (...). Two hands fold into one, a gesture meant to carry man into the great oneness. (...) the hand's gestures run everywhere

\footnotetext{
228 "Poverty", p. 6. Original: "Das Reichwerden folgt dem Armseyn nicht nach wie die Wirkung auf die Ursache, sondern das eigentliche Armseyn ist in sich das Reichseyn". GA 73, p. 880.

${ }^{229}$ INWOOD, M. A Heidegger Dictionary, p. 23.

${ }^{230}$ Original: "a humildade, que, etimologicamente, prende-se a humus, 'terra', de que o homo, 'homem', que igualmente provém de humus, foi modelado". BRANDÃO, J. Mitologia grega. Vol. 1 , p. 185. We could also wonder about the connection between humility (earth) and humidity, water.

231 "Poverty", p. 6. Original: "Arm sind wir nur, wenn sich bei uns alles auf's Geistige koncentrirt". GA 73, p. 881 .

232 "Poverty", p. 6. Original: "Die Concentration auf's Geistige bedeutet (...): sich auf die Beziehung des Seyns zum Menschen sammeln und gesammelt in ihr stehen”. GA 73, p. 880.
} 
through language, in their most perfect purity precisely when man speaks by being silent. (...) All the work of the hand is rooted in thinking [my highlights] ${ }^{233}$.

In Introduction to metaphysics, Heidegger says that thinking is the thinking of being (das Denken des Seins) ${ }^{234}$ in a twofold way. "Thinking is of being inasmuch as thinking, propriated [ereignet] by being, belongs [gehört] to being. At the same time thinking is of being insofar as thinking, belonging [gehörend] to being, listens [hört] to being"235. Thinking thinks and thinking thinks itself. Thinking is the disclosure of appropriation (Ereignis) $)^{236}$ as it is being that thinks and it is being thinking of being. The disclosure of appropriation is the translucence of being, its shining in brilliance. It is Being being in glory.

According to Heidegger,

Thinking is - this says: Being has embraced its essence in a destinal manner in each case. To embrace a 'thing' or a 'person' in their essence means to love them, to favor them. Thought in a more original way such favoring means the bestowal of their essence as a gift $\mathrm{ft}^{237}$.

In Mary, the gratuitous nature of things as a gift of the incessant rise enowns itself. "Be-ing poor (Armseyn) means being deprived of nothing except of what is not needed; it means being deprived of the liberating free and open. (...) What we

\footnotetext{
${ }^{233}$ What is called thinking?, p. 16. Original: "das Werk der Hand ist reicher, als wir gewöhnlich meinen. (...) Die Hand reicht und empfängt und zwar nicht allein Dinge, sondern sie reicht sich und empfängt sich in der anderen. Die Hand hält. Die Hand trägt. Die Hand zeichnet (...). Die Hände falten sich, wenn diese Gebärde den Menschen in die große Einfalt tragen soll. (...) die Gebärden der Hand gehen überall durch die Sprache hindurch und zwar gerade dann am reinsten, wenn der Mensch spricht, indem er schweigt. (...) Alles Werk der Hand beruht im Denken”. GA 8, p. 16.

${ }^{234}$ I would like to recall here note 163 in which I quoted Inwood: "a change of vocabulary does not automatically entail a change of thought". Heidegger preference, later in his work, for a different vocabulary might involve "an expansion of (...) meaning (...) but not necessarily a substantial change of thought". See INWOOD, M. A Heidegger Dictionary, p. 8.

235 "Letter on 'humanism", p. 241. Original: "Das Denken ist des Seins, insofern das Denken, vom Sein ereignet, dem Sein gehört. Das Denken ist zugleich Denken des Seins, insofern das Denken, dem Sein gehörend, auf das Sein hört". GA 9 [148], p. 316.

${ }^{236}$ According to Heidegger, the word enowning (Ereignis) is "taken into the service of a thinking that attempts to keep in memory that dark word of Parmenides: $\tau$ ò av̉ to - the same is thinking and being". "Bremen and Freiburg lectures", p. 117. Original: "in den Dienst eines Denkens

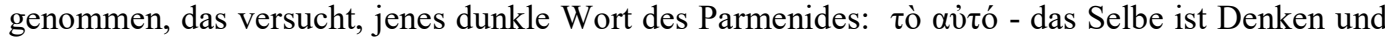
Sein, im Gedächtnis zu behalten”. GA 79, p. 125.

237 "Letter on 'humanism", p. 241. Original: "Das Denken ist — dies sagt: das Sein hat sich je geschicklich seines Wesens angenommen. Sich einer $>>$ Sache $<<$ oder einer $>>$ Person $<<$ in ihrem Wesen annehmen, das heißt: sie lieben: sie mögen. Dieses Mögen bedeutet, ursprünglicher gedacht: das Wesen schenken". GA 9 [148], p. 316.
} 
are deprived of we do not have, but it has us [my highlight]"238. This means "residing in a relationship to that which liberates"239, to the open.

To be in one's own nature, is to 'free' it to one's own being, "to 'free' it (...) into a preserve of peace. To dwell, to be set at peace, means to remain at peace within the free, the preserve, the free sphere that safeguards each thing in its nature" ${ }^{240}$. When someone passes away, we usually say: 'rest in peace'. The death is associated to a return to the beginning, or even to a new beginning. Mary, as a poor deceased, is also the "Queen of peace"241.

In the notorious fragment 5, Parmenides declares that "but thinking and Being are the same"242, "to gar auto noein estin te kai einai". According to Heidegger, "The type and direction of the opposition between Being and thinking are unique because here the human being comes face to face [Angesicht] with Being [my highlight]"243. This relation of man to Being happens in the mysterious strangeness of what is usually taken as familiar, as habitual. We have mentioned that a thing is the mysterious. This mystery is related to the familiar as that which appears and it is related to the strange as that which is not completely grasped. For Heidegger, "The inception is what is most uncanny and mightiest"244. Let's pay attention to Heidegger's play of words. The mystery is, in German, Geheimnis. The uncanny ${ }^{245}$, the strange, is the unheimlich. What is usual, familiar, is the heimlich ${ }^{246}$. The homeland is the native land, the place of origin or beginning,

\footnotetext{
238 “Poverty", p. 7. Original: "Armseyn heißt: $\mathrm{n}$ ichts entbehren, es sey denn das Unnötige - nichts entbehren als das Freie-Freiende. (...) Was wir entbehren, haben wir nicht, aber das Entbehrte hat uns". GA 73, p. 879.

239 "Poverty", p. 7. Original: “der Beziehung zum Freienden stehen”. GA 73, p. 879.

240 "Building Dwelling Thinking", p. 147. Original: "freien: einfrieden. Wohnen, zum Frieden gebracht sein, heißt: eingefriedet bleiben in das Frye, d.h. in das Freie, das jegliches in sein Wesen schont". GA 7 [143], p. 151.

${ }^{241}$ This is also one of Mary's titles.

${ }^{242}$ IM [104], p. 145. GA 40 [104], p. 145. Original: "Das selbe aber ist das Denken und das Sein".

${ }^{243}$ IM [108], p. 150-151. GA 40 [108], p. 150. Original: "Art und Richtung des Gegensatzes von Sein und Denken sind deshalb so einzigartig, weil hier der Mensch dem Sein ins Angesicht tritt". ${ }^{244}$ IM [119], p. 165. Original: "Der Anfang ist das Unheimlichste und Gewaltigste". GA 40 [119], p. 164.

${ }^{245}$ A note of the translator of Introduction to Metaphysics says: ""Uncanny" translates unheimlich, which is based on the root Heim, or home. ("Canny," like the German heimlich, can mean "snug and cozy." The root of "canny" is "can" in the obsolete sense of "know." What is uncanny is unfamiliar, beyond our ken, and thus unsettling.)". IM, p. 160.

${ }^{246}$ See glossary.
} 
where something is brought into emergence (her-vor-bringen). In German, it is called Heimat. All these words are related in some way to 'heim', which might mean house, home or dwelling place. They indicate the mystery (Geheimnis) as being the thing in the sense of that in which the mutual belonging of the uncanny and the familiar dwell as the mutual belonging of the unhabitual and the habitual. The mystery (Geheimnis) is the secret as what dwells in the most private ${ }^{247}$, as what is concealed in the ownmost.

\section{Ge H E I M nis -} Mystery (the most private)

Un H E I M lich - unhabitual H E I M lich- habitual
HE I M at -

Homeland, place of beginning

Again, this mystery is a mystery of the mutual belonging of concealment and unconcealment, of appearing and withdrawing. Heidegger says that "being on the earth (...) remains for man's everyday experience that which is from the outset 'habitual' - we inhabit it, as our language says so beautifully: it is the Gewohnte [the habitual] [my highlight]" 248 . We are used that things are. We are used to being on the earth, to inhabiting, to dwelling. The mystery is that things are or that a thing is. It penetrates all things. It traverses everything as the incessant rise of physis. We need to be out of home (unheimischen), in the unhabitual as the uncanny (unheimlich), in order to be authentically at home (einheimischen) in the familiar (heimlich), that is: to authentically inhabit the habitual. It is like the

\footnotetext{
${ }^{247}$ Privacy is related to the homely.

248 "Building Dwelling Thinking", p. 145. Original: "auf der Erde sein, bleibt nun (...) für die alltägliche Erfahrung des Menschen das im vorhinein, wie die Sprache so schön sagt, >> Gewohnte <<". GA7 [141], p. 149.
} 
exemple of the ordinary looking at the sun, that is: looking at it without dimensioning it yet. The strangeness brings us to the authentic dimension of our being on earth. The homeland (Heimat) is what holds the mystery of this incessant rise, the mystery of beginnings. Its character of native place might rise in brilliance once its authentic character comes to shine. A thing would then be filled with mystery, it would be full of mystery. As Heidegger says: "The uncanniest is what it is because it harbors such an inception[. It harbors such an inception] in which, from overabundance, everything breaks out at once into what is overwhelming and is to be surmounted" 249 .

The measure ${ }^{250}$ as a regioning is uncannily associated to the inception in Genesis. According to this book of the Bible, in the beginning, the waters were set apart and a region was opened. "God said, 'Let there be a vault through the middle of the waters to divide the waters in two.' And so it was. God made the vault, and it divided the waters under the vault from the waters above the vault. God called the vault 'heaven'[, caelum]"251. The Vulgata version ${ }^{252}$ presents the word 'firmamentum' as the correspondent to 'vault'. The Latin word helps to see the intimacy between this that was sustained, fixed firm, to a tension. A note on the Jerusalem Bible indicates that the vault was also called the arch of the sky, which "was a solid dome holding the upper waters [my highlight]"253. This tension sustains firm and opens a region ${ }^{254}$. The $\operatorname{arch}^{255}$ indicates the tension between the sky and the earth ${ }^{256}$, a tension that holds steadfast. Heidegger says that " 'Fixed' means outlined, admitted into the boundary (peras), brought into the

\footnotetext{
249 IM [119], p. 166. Original: "Das Unheimlichste ist, was es ist, weil es einen solchen Anfang birgt, in dem alles zumal aus einem Ubermaß in das Uberwältigende, Zubewältigende ausbricht". GA 40 [119], p. 164.

250 "the art of measurement is, after all, about all the things that come into being". PLATO, Statesman, 285 a.

${ }^{251} \mathrm{Gn}, 1,6-8$.

252 The Septuagint, Greek version of the Bible, uses 'steréoma', steadfastness. See: http://www.perseus.tufts.edu/hopper/text?doc=Perseus\%3Atext\%3A1999.04.0058\%3Aentry\%3Ds tere $\% 2$ Fwma

253 The Jerusalem Bible, p. 5.

${ }^{254}$ Mary's womb also makes room to hold the heaven, its openness has the wisdom to sustain firm.

${ }^{255} \mathrm{Cf}$. Heidegger's readings on Heraclitus.

${ }^{256}$ On a first moment, earth is a formless void, not yet dry land. In Greek Mythology, the origin is sometimes associated to a whirlwind, which could be thought as water in relation to itself, in this case, turning and sheltering an emptiness. The whirl-wind is also related to the air in motion, which is associated to the word spirit, the breath of life. The whirlwind forms a spiral, which evokes the spiritual and the rainbow as the arc of light, a spiral of light, a bridge between the earth and the sky or a sign of the covenant between the sky and the earth. In Chinese mythology, the rainbow is also associated to the stairway of seven colors. Cf. CHEVALIER, p. 71.
} 
outline (...). Boundary sets free into the unconcealed; by its contour in the Greek light the mountain stands in its towering and repose" 257.

Nevertheless, "We have killed him [God]"258. But how? "How were we able to drink up the sea? Who gave us the sponge to wipe away the entire horizon? What did we do when we unchained this earth from its sun?"259. The rise of the subject is the rise of the killer of God. The entification of Being is also its forgottenness. The transformation of Being in an experience of the subject is the objectification of the rising of physis. But let's remember that, as shine, the appearing is at work even in the inauthentic. For Heidegger, the loss of the gods does not exclude religiosity. "Rather, it is on its account that the relation to the gods is transformed into religious experience" 260 . This means that the subject is the one who now experiences. It is not Being anymore that is understood as that which "experiences" itself. It is not anymore a matter of the same, as the incessant rise, being, appropriating itself.

The mysterious is full mystery in authenticity, but it is also the mystery in inauthenticity. Even the forgottenness is a way of Being being. The forgottenness is also mysterious. The inception is mysterious as that which appears be it authentically or inauthentically. Such appearing is what need to be surmounted in the sense that it is always also withdrawal. Heidegger says that

the genuineness and greatness of historical knowing lie in understanding the character of this inception as a mystery. Knowing a primal history is not ferreting out the primitive and collecting bones. It is neither half nor whole natural science, but, if it is anything at all, it is mythology ${ }^{261}$.

In Heidegger's remarks on an extract of Sophocles Antigone, he gives important clues on how to hear the naming of sea and earth.

\footnotetext{
${ }^{257}$ OWA, in PLT, p. 82. Original: " $>>$ Fest $<<$ besagt: umrissen, in die Grenze eingelassen $(\pi \varepsilon \rho \alpha \zeta)$, in den Umriß gebracht (...). Grenze gibt frei ins Unverborgene; durch seinen Umriß im griechischen Licht steht der Berg in seinem Ragen und Ruhen". GA 5 [68], p. 71.

${ }^{258}$ NIETZSCHE Apud HEIDEGGER, "The word of Nietzsche: 'God is dead' ", p. 106. Original: " $>>$ Wir haben ihn getötet $<<"$. GA 5 [241], p. 246.

${ }^{259}$ NIETZSCHE Apud HEIDEGGER, "The word of Nietzsche: 'God is dead" ”, p. 106. Original: " $>$ Wie vermochten wir das Meer auszutrinken? Wer gab uns den Schwamm, um den ganzen Horizont wegzuwischen? Was taten wir, als wir diese Erde von ihrer Sonne losketteten? <<". GA 5 [241], p. 246.

${ }^{260}$ AWP, p. 208. Original: "[Aber die Entgötterung schließt die Religiosität so wenig aus, daß] vielmehr erst durch sie der Bezug zu den Göttern sich in das religiöse Erleben abwandelt”. GA 5 [70], p. 76.

${ }^{261}$ IM [119], p. 166.
} 
the naming of sea and earth does not intend the things it names in a merely geographical or geological way. (...) But here [in Antigone], "sea" is said as if for the first time; it is named in the wintry swells in which it constantly drags up its own depths and drags itself down into them.

The sea is thought in relation to its own depths. But what does 'earth' mean in an originary way? In The Origin of the work of art, Heidegger gives a hint on a way of apprehending what he intends to mean by 'earth'. This time, the understanding of the physis rising helps us to get there.

The Greeks early called this emerging and rising in itself and in all things phusis. It clears and illuminates, also, that on which and in which man bases his dwelling. We call this ground the earth. What this word says is not to be associated with the idea of a mass of matter deposited somewhere, or with the merely astronomical idea of a planet. Earth is that whence the arising brings back and shelters everything that arises without violation. In the things that arise, earth is present as the sheltering agent ${ }^{262}$.

The sea, as the waters, names the relation to its own depths and the earth names the sheltering agent of this relation to itself. According to Heidegger, "God is not dead, because its divinity lives. (...) the divinity, as presencing, receives its provenance of the truth of being" 263 .

The division of waters "in two", thought in the light of the truth as alétheia ${ }^{264}$, could wink to a scenario where the upper waters and the waters under the vault are facing each other. There would be a face-to-face encounter of waters, an Entgegenblick, we could risk. The cleft of waters might also remind us of the reference to pain, the holy pain, which is the joining of the rift. Mountains ${ }^{265}$ are

\footnotetext{
${ }^{262}$ PLT, p. 41. GA 5, [31], p. 28. Original: "Dieses Herauskommen und Aufgehen selbst und im Ganzen nannten die Griechen frühzeitig die phusis. Sie lichtet zugleich jenes, worauf und worin der Mensch sein Wohnen gründet. Wir nennen es die Erde. Von dem, was das Wort hier sagt, ist sowohl die Vorstellung einer abgelagerten Stoffmasse als auch die nur astronomische eines Planeten fernzuhalten. Die Erde ist das, wohin das Aufgehen alles Aufgehende und zwar als ein solches zurückbirgt. Im Aufgehenden west die Erde als das Bergende.”.

${ }^{263}$ My translation. "Notes from the workshop". Original: "ist Got nicht tot. Denn seine Gottheit lebt. (...) die Gottheit als Wesendes seine Herkunft aus der Wahrheit des Seins empfängt". GA 13, 154.

${ }^{264}$ That is: not in a metaphysical approach.

265 "God said, "Let the waters under heaven come together into a single mass, and let dry land appear.' And so it was. God called the dry land 'earth' and the mass of waters 'seas' ". Gn 1, 9-10. Cf. IM [117-118] to check Heidegger analysis of Sophocles reference to the sea and the earth.
} 
said to shelter this pain, as earth rushing itself to the sky ${ }^{266}$. Mountains, as part of the water that came together in a single dry mass, are dry and thirsty land ${ }^{267}$ that rises in seek of the upper waters. The Virgin Mary is associated to the symbolism of mountains close to lakes. While mountains are the earth that rushes to the sky, a 'rising ground" ${ }^{268}$, the lakes evoke the sky coming down to earth. When it rains, we use to say that the sky ("firmamentum") is falling ${ }^{269}$, as if it were coming down. The waters are then a metaphor to the sky on earth. As mountains surrounding lakes, Mary is thus related to the earth that holds the sky - or the Christ on her womb. She is a mountain (Berg) that shelters (bergen) pain, a temple of the spirit.

We could say that we are all mountains as well, since "[man] is itself the clearing [Lichtung]"270. Man is this possibility of being a temple of the gold, because man has the capacity to think. To unconceal, unconcealment, "Unverborgen(heit) comes from verbergen, 'to hide, conceal', especially things about one's person or one's inner life. Verbergen comes from bergen, 'to bring to safety', and retains the flavour of protecting something" ${ }^{271}$. There seems to be two different ways of reaching this sense of 'protecting' ${ }^{272}$. One is related to the protecting character of a range of mountains that shelters with its height what is close to it. The other one is related to a root of 'bergen' that links it to the meaning of "to bury", which gives new dimensions to the meaning of "to lay somewhere to safe keeping" ${ }^{273}$. Berg means mountain, but it is also linked to the meaning of barrow ${ }^{274}$. The mountain is at the same time the rising ground and the barrow. It appears and safeguards.

The mountain association with the barrow gives new meanings to Heidegger's remark that the "most thought-provoking for our thought-provoking

\footnotetext{
${ }^{266} \mathrm{Cf}$. note 62 .

${ }^{267}$ Despite the reference to something that sounds material and that Heidegger has just criticized in the previous quotation, it is important to keep in mind the understanding of it as a sheltering agent. This means to hear this land as a thing thirsty for its ownmost, being an incessant and silent call. To miss our homeland as our home is said in German Heimweh, homesickness.

268 See Kluge Dictionary, p. 27.

269 The rain is also associated to the rain-bow, a bridge (or a bow, an arc) between the sky and the earth. Cf. CHEVALIER, p. 71. To bow means to bend, to incline, thus it can also designate something that is arched. Cf. the relations of these considerations to Heidegger's remarks on the issue of the homologein.

${ }^{270}$ See BT, GA 2 [133].

${ }^{271}$ INWOOD, M. A Heidegger Dictionary, p. 237.

${ }^{272}$ See Kluge Dictionary, p. 27.

${ }^{273}$ See Kluge Dictionary, p. 27.

${ }^{274}$ See Kluge Dictionary, p. 27.
} 
time is that we are still not thinking" 275 . The most thought-provoking is that "this most thought-provoking thing turns away from us" ${ }^{\text {276 }}$, that it insistently withdraws from us. That's why the twilight (der Abend) "be it of the day or of life"277 is always a time for thinking, because it refers to the instant (of lightning) that is always running away. It echoes here Heidegger's words previously quoted that, as the stranger, the deceased is buried in the ground and yet lives. The barrow safeguards the concealment in unconcealment. If we want to feel closer to the ancient life of the dead, if we want to find again a place of belonging or search our origins, we might need to look at the graveyard.

In Meßkirch's seventh centennial (700 Jahre Meßkirch), Heidegger suggests that in the cemetery grows the remembrance of our home and of everything that is lasting $^{278}$. The philosopher mentions two ways the German language has to call the burial ground. One of them is Gottsacker, which literally means God's acre, God's land. Heidegger indicates the possibility of associating this term with the interpretation that,

In this ground, it is sown always anew the memory [Erinnerung] of what has been. Thus, in this ground, grows the remembrance [Andenken] of the forefather's house and of the time of youth, and with it, the remembrance [Andenken] of all the forces and powers that bestow everything that is salutary, fruitful and lasting, and sometimes also what is meaningful ${ }^{279}$.

For Heidegger, remembrance [Andenken] is thinking of [An-denken]. Haar elucidates that "An-denken is taken in the modified sense of Denken am Sein selbst, thought that keeps itself alongside being itself" ${ }^{280}$. Remembrance is then enowning as thinking thinking itself, as the memory of the ownmost of things,

275 "What is called thinking”, p. 17. Original: "das Bedenklichste für unsere bedenkliche Zeit ist, daß wir noch nicht denken". GA 8, p. 19.

276 "What is called thinking", p. 17. Original: "jenes Bedenklichste sich von uns abwendet". GA 8, p. 19.

277 Original: "sei es des Tages, sei es der des Lebens". GA 16, p. 574.

278 See "Messkirch's Seventh Centennial".

${ }^{279}$ My translation. See also "Messkirch's Seventh Centennial”, p. 53. Original: “Auf diesem Acker wird immer neu die Erinnerung an das Gewesene gesät. So wächst auf diesem Acker das Andenken an das Eltern haus und an die Jugendzeit und mit i h r das Andenken an all die Kräfte und Mächte, die das Heilsame spenden, das Fruchtbare und das Bleibende, bisweilen auch das Bedeutende". GA 16, p. 580.

${ }^{280}$ HAAR, M. Heidegger and the essence of man, p. 99. Haar continues: "The word [Andenken] is identified with An-dacht, a term borrowed from the language of religious devotion and that designates the gathering of the soul in prayer or devoutness (thus the worship of the Holy Sacrament is called Andacht). Andacht, Heidegger says, means the 'gathering of the soul' (Gemüt) alongside with being' ". See also GA 8, What is called thinking?. 
that which constantly withdraws and, nevertheless, is inherent to everything that is. Because it concerns Being as the incessant rise, it concerns not only the has been, but also the being and the coming to be.

The other German word for graveyard is Friedhof, which literally means peace yard. In Building Dwelling Thinking, he traces a connection between peace, the free and the safeguarded. According to him,

The Old Saxon wuon, the Gothic wunian, like the old word bauen, mean to remain, to stay in a place. But the Gothic wunian says more distinctly how this remaining is experienced. Wunian means: to be at peace, to be brought to peace, to remain in peace. The word for peace, Friede, means the free, das Frye, and fry means: preserved from harm and danger, preserved from something, safeguarded ${ }^{281}$.

To remain in the free, to be at peace is to remain in one's ownmost, which rests safeguarded. It is to find again "the silence and the gathering" 282. As barrows, mountains are a sign of the withdrawal of the rising ground ${ }^{283}$. In The origin of the work of art, Heidegger says: "the earth rises up. It shows itself as that which bears all, as that which is secure in its law and which constantly closes itself up. (...) Earth, bearing and rising up, strives to preserve its closedness and to entrust everything to its law" 284 .

Chinese landscape paintings "focuses preeminently on earth as it is displayed, not so much in expansive landscapes in the Western sense, but in its upsurge in the shape of mountains" 285 . Landscape is composed by 'land' and 'scape'. 'Land' refers to that which we belong to, whereas 'scape' is related to the suffix '-ship'. "Merriam-Webster lists 'nature, condition and quality' as synonyms of the Germanic etymological roots of -ship, stating that these are etymologically

\footnotetext{
281 "Building Dwelling Thinking", p. 146-147. Original: "Das altsächsische $>>$ wunon $<<$, das gotische $>>$ wunian $<<$ bedeuten ebenso wie das alte Wort bauen das Bleiben, das Sichaufhalten. Aber das gotische $>>$ wunian $<<$ sagt deutlicher, wie dieses Bleiben erfahren wird. Wunian heißt: zufrieden sein, zum Frieden gebracht, in ihm bleiben. Das Wort Friede meint das Freie, das Frye, und fry bedeutet: bewahrt vor Schaden und Bedrohung, bewahrt - vor ... d. h. geschont". GA 7 [143], p. 150-151.

${ }^{282}$ Original: "die Ruhe und Sammlung". GA 16, p. 581.

${ }^{283}$ Lacoue-Labarthe says that the Sistine Madonna is a unique stele. This word is often used to refer to a gravestone, a funerary or commemorative monument or to a boundary marker. See $L a$ vraie semblance, p. 67.

${ }^{284}$ OWA, in OBT, p. 38. Original: "kommt die Erde zum Ragen. Sie zeigt sich als das alles Tragende, als das in sein Gesetz Geborgene und ständig Sichverschließende. (...) Erde trachtet, tragend-aufragend sich verschlossen zu halten und alles ihrem Gesetz anzuvertrauen". GA 5 [51], p. $50-51$.

${ }^{285}$ SALLIS, J. "Effacements of form”, p. 646.
} 
'akin to Old English sceppan, scyppan, meaning to shape' "286. Land-scape would thus be associated to the nature of land or to the shape of the land ${ }^{287}$. We could then think the land-scape as the shape (of that) to which we belong to, that is

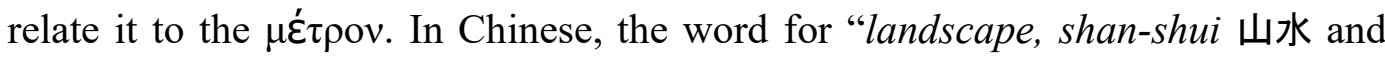
shan-chuan 山川, mean literally mountains-and-waters and mountains-andstreams, respectively" ${ }^{288}$. Sallis analysis on Guo $\mathrm{Xi}^{289}$ writings elucidates that there are three distances "that can be set out in painting a mountain" 290 :

(1) The high-distance, $[\uparrow]$ or $[\mid]^{291}$

which refers to "looking up from the foot to the top";

(2) The deep-distance, $[\leftarrow]$ or $[-]$

which refers to "looking from the front toward the back";

(3) The level-distance, $[\leftrightarrow]$ or $[\cdot]$

which refers to "looking across from one mountain to another".

All these three ways of setting out a distance could be seen as ways of referring to a mutual bringing or a mutual belonging, be it as an intimacy of foot and top as sky and earth or front and back as concealment and unconcealment. The level-distance ${ }^{292}$ is particularly special here, since it might be particularly linked to the Antlitz as Entgegenblick. The looking across each other characteristic of the level-distance might be related to an en-countering glance (Entgegenblick) as arrival (Ankunft), that is: to a glance turned toward that which is brought forth in its arrival, in its setting up a region. A mountain faces another mountain, a

\footnotetext{
${ }^{286}$ OLWIG, K. "Representation and alienation in the political land-scape", p. 37.

${ }^{287}$ Cf. OLWIG, K. "Representation and alienation in the political land-scape", p. 21.

288 SALLIS, J. "Effacements of form", p. 646.

${ }^{289}$ Guo Xi was a landscape painter "who not only produced exemplary paintings but also provided the most important treatise on landscape painting in the history of Chinese art. This treatise (...) [is] entitled The Lofty Powers of Forests and Brooks (Lin Quan Gao Zhi"). In: SALLIS, J. "Effacements of form", p. 645.

290 SALLIS, J. "Effacements of form", p. 646.

291 The graphic signs are my suggestions.

${ }^{292}$ If we pay attention to the two cherubim, we would notice that they are looking up from the foot to the top, what characterizes the high-distance, and from the front toward the back, what characterizes the deep-distance. The cherub closer to Saint Barbara seems to be exchanging glances with her. They seem to be looking across one another. The other cherub seems to be looking at the mutual bringing of the Mother and the Son, which, as has been mentioned, stares the mutual bringing of the (canvas) window that forms a (curtains) window. This looking across each other might be linked to the level-distance.
} 
double of itself that calls for its own provenience. In Chinese landscape painting, it is also required that the painter "set the entire scene explicitly within the space delimited by earth and sky"293. There is nothing outside this tension. The provenience is thought within this en-countering glance, within this mutual bringing, and through the region it discloses.

We have suggested here that the mutual bringing of the Madonna and her Son is turned toward the image bringing into emergence (das Bild (...) bildet) a window. The Madonna looks as if to a void and at the same time her figure with the Child stands before what faces them, a peculiar window. Standing before the window, they stand before a mutual belonging of concealment and unconcealment. For Heidegger, a window designs the openness of a disclosure as a seeing of the shining through. It is the openness of a translucence (das Offene des Durchscheinens) as the inapparent incessant rise shining through appearing. It is the union of clearing (Lichtung) and concealment (Verbergung) as "the movement of the clearing of self-concealment as such, from which, in turn, all self-illumination arises" 294 .

That this image (Bild) forms (bildet) a window means that the window as emerging from this form forming, from this essencing of the Bild (as Bildwesen), is Being being in the letting appear through a limit, a boundary. It gathers appearing in its ownmost constitution ${ }^{295}$. The window is the outlook of arrival as the outlook of the incessant rise. This image (Bild) is an image (Bild) "before the distinction of canvas and painted window"296, because it raises attention to the mutual belonging of concealment and unconcealment in that which appears. It is the bringing into emergence bringing into emergence the outlook of this incessant rise. As Heidegger says: the ownmost of the bringing of the mother and the Son is gathered "in the glancing look" 297 . In it, the figure (Gestalt) of their mutual bringing stands. The ownmost of both is placed (gestellt) in this sudden unapparent seeing.

\footnotetext{
${ }^{293}$ Id. Ibid.

${ }^{294}$ OWA, in OBT, p. 54. Original: "die [Bewegung] der Lichtung des Sichverbergens als solchen, aus dem wiederum alles Sichlichten herkkommt”. GA 5 [68], p. 71-71.

${ }^{295}$ See again [on page 57] the remarks on Athena being the one who meditates on the limit, the $\sigma \kappa \varepsilon \pi \tau \mathrm{O} \mu \varepsilon v \eta$. See also "The provenance of art and the destination of thought", GA 80.

${ }^{296}$ My translation. Original: "vor der Unterscheidung in $>>$ Fenstergemälde $<<$ und $>>$ Tafelbild <<". GA 13, p. 119.

297 My translation. Alternative: "in the seeing [of the] glance". Original: "in das blickende Schauen". GA 13, p. 121. (It has already been quoted. See note 69).
} 
'Ge-Stell' [placement] [ ${ }^{298}$ ] (...) is to be understood (...) [as]: the gathering together of the bringing-forth, the allowing to come forth into the rift as bounding design $(\pi \varepsilon \rho \alpha \zeta)$. The Greek meaning of $\mu о \rho \phi \varepsilon$ as figure [Gestalt] is clarified by 'Ge-Stell' understood in this way ${ }^{299}$.

The image (Bild) is this gathering as the suddenness ${ }^{300}$ of this unapparent appearing.

It is only "through Him that she [the Madonna] is herself brought forth"301 and it is only through the window design that the openness appears in its disclosure. The contour is what sets free into unconcealment.

The Greek 'setting' means: placing as allowing to arise, for example, a statue (...). 'Setting' and 'placing' here never mean the summoning of things to be placed over and against the self (the 'I' as subject) as conceived in the modern fashion. The standing of the statue (i.e., the presence of the radiance that faces us) is different from the standing of what stands over and against us [Gegenstand] in the sense of an object [Objekt]. 'Standing' (...) is the constancy of the radiance ${ }^{302}$.

It is the constancy of the mutual belonging of concealment and unconcealment as the incessant rise of physis. This mutual belonging "brings with it the sheltering

\footnotetext{
${ }^{298}$ See MITCHELL, A. "Translator's foreword". In: Bremen lectures, p. xi. Michell suggests translating Ge-stell as positionality. In OWA, the translation from Poetry, Language thought presents Ge-stell as "frame, framing, framework". This alternative is criticized by Michell. The OWA version from Off the Beaten track suggests 'placement'.

${ }^{299}$ OWA, in OBT, p. 54. See also PLT, p. 83. Original: " $>>$ Ge-stell $<<$ : die Versammlung des Her-vor-bringens, des Her-vor-ankommen-lassens in den Riß als Umriß (péras). Durch das so gedachte $>>$ Gestell $<<$ klärt sich der griechische Sinn von morphé als Gestalt". GA 5 [68], p. 72.

${ }^{300}$ This suddenness refers to the lightning-flash that will soon come into discussion. It is worth paying attention to Santa Barbara's connection with the lightning. The tower behind Saint Barbara is one of the elements that helps to identify this saint in the Sistine Madonna. Barbara was the daughter of Dioscorus, a pagan who locked her in a tower to protect her from the world. She was beautiful and rich. Since she refuses her marriage proposals, his father decided to let her go to the city, where she gets in contact with Christians. During her father absence, she ordered that $a$ third window was opened in her tower as sign of her conversion to the faith on the Holy Trinity. (It is interesting to notice that the Sistine Madonna is also said to be a third window). Furious, her father denounced her. After being tortured, she was condemned to death by beheading. Dioscorus himself carried out the sentence and just after was killed by a lightning. She is thus associated to the lightning and to the protection against sudden deaths.

${ }^{301}$ My translation. HEIDEGGER, M. Über die Sixtine, p. 120. Original: "sie selbst erst durch ihn her-vor-gebracht wird".

302 OWA, in OBT, p. 53. Original: "Das griechische $>>$ Setzen $<<$ besagt: Stellen als Erstehenlassen z. B. ein Standbild (...). Setzen und Stellen bedeuten hier nirgends das neuzeitlich begriffene herausfordernde Sich (dem Ich-Subjekt) entgegenstellen. Das Stehen des Standbildes d. h. das Anwesen des anblickenden Scheinens) ist anderes als das Stehen des Gegenstandes im Sinne des Objektes. $>>$ Stehen $<<$ ist (...) die Ständigkeit des Scheinens”. GA 5 [68], p. 70.
} 
concealment of its provenance" 303 . The contour sets free into unconcealment, not as an object, but rather as the unapparent appearing of this mutual belonging, which traverses everything. Gazing at the unapparent appearing of the mutual belonging, this peculiar pair of mother and Son gazes at Being being. This window brings into emergence a mutual bringing as a mutual belonging. As Heidegger says: "The image [Bild] does not appear later through an already existent window, but it is rather the image [Bild] itself that first forms [bildet] this window"304.

The mutual bringing that happens in the Sistine Madonna is a very special one, since, we could say, it looks at itself. There is a kind of face-to-face of mutual belongings, the one of the image forming a window as the openness of a disclosure and the one of the mutual bringing of mother and Son. It is not a faceto-face of two things as objects what is at stake, but it is rather the standing of things, their setting, that faces itself. The incessant rise of physis faces itself. The ownmost of things gathered in the openness of the window faces the ownmost of things gathered in the glancing look of the mutual bringing of mother and Son. Being being faces Being being.

According to Heidegger, this window is a glimpse into the outside, an outlook (Ausblick). This window stares an outside that manifests a mutual bringing, which is also a mutual belonging. Looking inside the canvas, we look outside the window. The mutual bringing of the Madonna and her Child, staring the window, also stands before the outside of the canvas, which might be seen as the inside of an abyssal depth. Inside and outside are insistently redesigned and puzzled in this play of glances. This mutual reference and its constant recast points to an intimacy of both. This familiarity is the affinity of what conceals and unconceals itself, which happens in many ways through this image (Bild), be it through this recast or through the strange face-to-face of mutual belongings, for example. According to Lacoue-Labarthe, "The window is ab-solument apophantic; it makes possible this impossible: to make appear the appearing"305.

\footnotetext{
${ }^{303}$ My translation. HEIDEGGER, M. Über die Sixtine, p. 120. Original: “das verborgen Bergende ihrer Herkunft mit-er-bringt".

${ }^{304}$ My translation. Original: "erscheint das Bild nicht nachträglich durch ein schon bestehendes Fenster, sondern das Bild selber bildet erst dieses Fenster". GA 13, p. 120.

${ }^{305}$ My translation of: "La fenêtre est ab-solument apophantique; elle rend possible cet impossible: faire paraître le paraitre". LACOUE-LABARTHE, P. "La vraie semblance", p. 54.
} 
In this context, it is also interesting to notice that the Sistine Madonna is said to be a third window, since it is an image of a window between two other windows at the San Sisto Church in Piacenza ${ }^{306}$. Usually, windows in churches are stained glass windows ${ }^{307}$. This means that they let the light traverse them, making an image appear. If we understand image in the originary sense Heidegger suggests, that is, as a bringing into emergence the shining radiance of beings, then the Sistine as window, when in its authentic essencing, would make appear the bringing into emergence as the shining radiance of beings. This essencing as an intimacy with a brilliant shine became opaque in times of forgottenness. To be in its authentic essencing means the image (Bild) to be in relation to its own shine, letting it appear in brilliance through the Gebild ${ }^{308}$.

To let shine through itself is to let being appropriates itself, to allow a disclosure of appropriation (Ereignis). Heidegger states that the "self-lighting is the lightning-flash" ${ }^{\text {309. }}$.

'To flash' [blitzen], according to the word and the issue at stake, is to glance [blicken]. In the glance [im Blick] and as the glance, what is essencing enters into its own illumination. Through the element of its illumination, the glance shelters back in the glancing whatever it catches sight of; at the same time, glancing likewise guards in illumination the hidden darkness of its provenance as what is unilluminated. Entrance [Einkehr] of the lightning flash of the truth of being is insight $[\text { Einblick }]^{310}$.

This "insight into that which is" 311 means also an insight into a mutual belonging. Mitchell comments on the use Heidegger makes of the word entrance (Einkehr) specifying that "Whatever enters with an Einkehr does not enter directly. There is a sweep to this entrance, it traces an arc, it is spaced. Einkehr is the way something enters that has been here all along, though inapparently"312.

\footnotetext{
${ }^{306}$ See figures 6 and 7 in appendix.

${ }^{307}$ It is worth mentioning that La Farge made a stained glass window (1890-1891) inspired by the Sistine Madonna. It is housed in Our Lady of Mercy Chapel in Newport. See YARNALL, J. "John La Farge's Windows for the Caldwell Sisters of Newport". See figure 7 in appendix.

${ }^{308}$ The word is used in its ambiguity: the image constituted and the constitution of the image.

${ }^{309}$ Bremen lectures, p. 70. GA 79, p. 74. Original: "Das (..) Sichlichten ist das Blitzen".

${ }^{310}$ Bremen lectures, p. 70. GA 79, p. 74. Original: "Blitzen« ist dem Wort und der Sache nach: blicken. Im Blick und als Blick tritt das Wesen in sein eigenes Leuchten. Durch das Element seines Leuchtens hindurch birgt der Blick sein Erblicktes in das Blicken zurück; das Blicken aber wahrt im Leuchten zugleich das verborgene Dunkel seiner Herkunft als das Ungelichtete. Einkehr des Blitzes der Wahrheit des Seyns ist Einblick".

${ }^{311}$ Bremen lectures, p. 70.

${ }^{312}$ MITCHELL, A. "Translator's foreword”. In: Bremen lectures, p. xi.
} 
The mutual belonging of concealment and unconcealment is inapparently here all along. Its tension spaces. The entrance within this tension, this in-cident (Zwischen-fall) ${ }^{313}$, this fall-in-between, is a glimpse on what constitutes oneself, on the unapparent mutual belonging of concealment and unconcealment. It is a glimpse on one's own, a turn (Kehre) to itself. This helps us to understand the encountering glance (Entgegenblick) aspect as this strange face-to-face with itself, as an appropriation of the mutual belonging by itself. Michell also clarifies that

the 'gegen' here is not to be understood as an 'over against' as per modern metaphysics, but instead as an 'entgegen,' a 'toward.' The gegen of Gegenwart is a directional term specifying the way in which the present that waits leans toward us or is inclining itself to us. The present is not present, but something that slants toward us, that is impending. The present, too, arrives ${ }^{314}$.

This glance is a turn toward what constitutes the structure of alétheia, as a turn toward the mutual belonging of concealment and unconcealment. The turn of the entrance is a toward itself as a toward one's ownmost.

If unconcealment and concealment are thought in terms of illumination and unillumination, an important aspect about the role of the unilluminated aspect in illumination might become clearer. The unillumination makes contour, landscape, since unillumination gives depth to the ensemble, as a shadow also does. The landscape relates illumination and unillumination in oneness. Heidegger conceives oneness (Einheit) as "not empty one-and-the-sameness, not selfsameness as a merely indifferent all-the-sameness. Oneness[, for him,] is the belonging together of that which contends. This is what is originally unified" 315 . The contend of concealment and unconcealment, tensions an arc, the arch of everything and each thing that is. This arc carries out a mutual belonging as the mutual belonging of sky and earth or of illumination and unillumination. As an intimate covenant, we might think this arc as an ark. In its standing dwells a mutual belonging. Each thing and everything might be thought as mirroring this arc, as the mountain that is at once the rising ground and the barrow.

\footnotetext{
${ }^{313}$ IM [125]. GA 40 [125], p. 172.

${ }^{314}$ MITCHELL, A. "Translator's foreword". In: Bremen lectures, p. xiii.

${ }^{315}$ IM [106]. GA 40 [106], p. 147. Original: "ist hier nie leere Einerleiheit, nicht Selbigkeit als bloße Gleich-gültig-keit. Einheit ist Zusammengehörigkeit des Gegenstrebigen. Dies ist das ursprünglich Einige".
} 
The belonging together of sky and earth might be thought not only through the Chinese landscape painting of the earth upsurge in the shape of mountains. In Chinese, there is another word for landscape, that is fengjing, 风景, which is related to Feng, 风, that means wind. To paint the wind is an attempt to paint the unapparent, to bring forth this mutual belonging of concealment and unconcealment, of arrival and provenience. 'Jing' means bright or view, scenery $^{316}$. The landscape would be then the wind's bright, the shine of the wind, its 'appearing', its scenery. If we associate the wind to the unapparent, the landscape as the shine of the wind would refer to the unapparent appearing of the mutual belonging of concealment and unconcealment. Chinese landscape painting as the painting of the wind's shine could be thought then as the painting of a mutual belonging. It is interesting noticing that, for $\mathrm{Guo} \mathrm{Xi}$, "The color of wind can be achieved by the use of yellow clay or ink made of soot"317. Yellow or soot, we could hear: gold or fire, spirit, that which is the animator and that shines through everything and each thing that is.

Heidegger clarifies that spirit does not mean spiritual as opposed to what is material. This would still be a distinction guided by a metaphysical kind of thinking that institutes two separated realms. This kind of metaphysical approach entify and set apart what must be thought in terms of withdrawal and nearness and the oneness of this contend. The Ein-kehr, entrance, speaks of a Kehre, a turn toward this constitutive mutual belonging, an en-countering of this unapparent reciprocity with itself.

Sallis defends that

the Renaissance conception of a painting (formulated by Alberti) as a window into another space of pure images was never operative in Chinese painting. Not only might the painter himself add inscriptions in the space of the painting, for instance, a poem or an account of the circumstances of the painting; but also persons other than the painter often added inscriptions of various kinds, sometimes at a much later date dis. $^{318}$

\footnotetext{
${ }^{316}$ See: http://dictionary.pinpinchinese.com/definitions/s/\%E6\%99 \%AF-jing.

${ }^{317}$ SALLIS, J. "Effacements of form", p. 650.

${ }^{318}$ SALLIS, J. "Effacements of form", p. 652
} 
Sallis gives the example of Zhu Derun's Cosmic circle (浑沦图) $)^{319}$, “The work is composed as if to open communication between $\left[{ }^{320}\right]$ the natural landscape, on the one side $\left[{ }^{321}\right]$, and the figural and written meditations $\left[{ }^{322}\right]$ of Daoist philosophy, on the other" ${ }^{\prime 323}$. A cloudlike rock on a shoreline faces the meditations ${ }^{324}$ while a windblown joins them together. It is interesting to notice that "Zhu's signature 'Merged with the Void Mountain Man' asserts the artist's identification with the image, which evokes both all of Nature and emptiness" ${ }^{\text {"25. }}$. It evokes the mutual belonging of both in oneness and in the void mountain $\operatorname{man}^{326}$. Zhu identification with all nature and emptiness and with the mountain is an identification with a belonging to the mutual belonging of the rising of physis and its withdrawal. The face-to-face of the natural landscape and the written meditations might refer to the mirroring of the incessant rise of physis in landscape with the ownmost of things sung in poetry, as a meditative thinking.

The Sistine Madonna, however, seems to be special in the Renaissance context. Belting argues that “The earlier painting [Raphael's Madonna of Foligno] contains a heavenly apparition; the Sistine Madonna, in contrast, is one. The work appeals to the inner vision, rather than creating the window illusion that has to be taken at face value" ${ }^{327}$. In this sense, we are allowed to see the Sistine otherwise,

\footnotetext{
319 This work is also referred as Primordial Chaos. See next page, figure 3. For the full handscroll, see figure 15 in the appendix.

320 "A perfect circle, obviously drawn with a compass, floats between the pine and Zhu's boldly brushed inscription. Unruly windblown vines extend rightward from the pine to the inscription, tying the composition together". HEAR, M. "Painting and Calligraphy under the Mongols", p. 224.

321 "the handscroll shows Li-Guo-style gnarled pine and cloudlike rock on a foreground shoreline fringed with grass". HEAR, M. "Painting and Calligraphy under the Mongols", p. 224.

322 "Zhu's inscription reads: 'Primordial chaos [hulun] is not square but round, not round but square. Before the appearance of heaven and earth there were no forms; yet forms existed. After the appearance of heaven and earth, forms existed but became undefined, their constant expansion and contraction, unfurling and furling, making them beyond measure". Apud HEAR, M. "Painting and Calligraphy under the Mongols", p. 224.

${ }^{323}$ SALLIS, J. "Effacements of form", p. 654.

${ }^{324}$ They might be said to be meditations on the immeasurable. See note 318 .

${ }^{325}$ HEAR, M. "Painting and Calligraphy under the Mongols", p. 225.

${ }^{326}$ In Chinese landscape paintings, usually, "What stand out are the mountains and especially the tallest peaks set at the center of the work" (p. 647). If we look carefully and open-hearted to the Sistine Madonna, we might see a chain of mountains in the painting: $\wedge \wedge$. The highest peak would appear as a Madonna with the Child 'at the center of the work'. "The master-peak is, says Guo Xi, 'like an emperor among his subjects, a master among servants" " (SALLIS, J. "Effacements of form", p. 649). Ebelerin says that "The serious-looking child has his legs crossed, in the traditional position of the ruler-jugde". ("The curtain in Raphael's Sistine Madonna", p. 72.) The expression "the void mountain man" might also make us think of Mary's poverty.

${ }^{327}$ BELTING, H. Likeness and presence, [290], p. 481.
} 


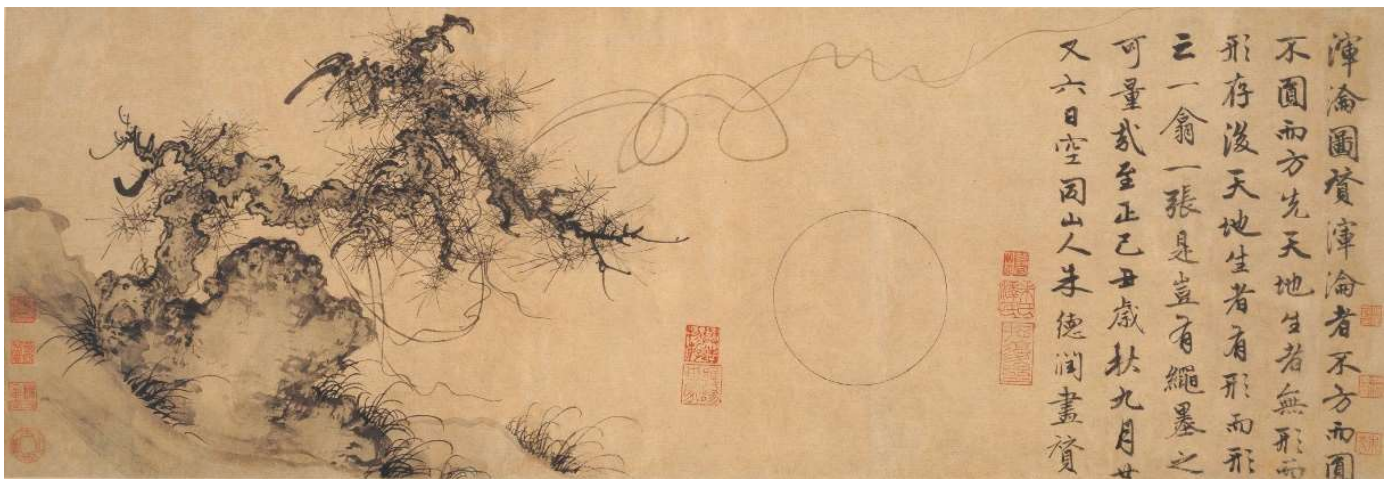

Figure 3

Primordial Chaos - Zhu Derun - 1349

Shanghai Museum, China 
that is: as the appropriation of a mutual belonging, as it facing itself in the image (Bild). This aspect would bring the Sistine Madonna closer to the Chinese painting in a way we might not have previously supposed.

This appropriation of the mutual belonging might also be thought through the mirroring of other two topics. The relation between the theme of the Madonna as arca Dei and the curtain motif might be a clue to trace the possibility of the mirroring of the image (Bild) forming a window and the mutual belonging of mother and Son. According to Eberlein, there is a "statistically strong correlation" 328 between them among interpreters. He declares that

Raphael $\left.{ }^{329}\right]$ had knowledge of the opened curtain as a pictorial motif used in depictions of Mary $\left[{ }^{330}\right]$. But this says little, to be sure, of the precise way in which the motif was available to Raphael, that is, how great a part was played by familiarity with its meaning as a sign of the virgin motherhood of the arca $D e i^{331}$.

In order to understand the role it might have played, let's pay attention to the report that the Sistine Madonna was intended to the high altar of the Church of S. Sisto in Piacenza. The Benedictine monastery of Piacenza holds in this church relics of Saint Barbara and Sixtus, which are the two figures of saints that appear on the Sistine canvas. The Pope Sixtus that appears on the painting is known to have Julius II features ${ }^{332}$, who commended the painting to Raphael and had Sixtus

\footnotetext{
${ }^{328}$ EBERLEIN, J. "The Curtain in Raphael's Sistine Madonna”, p. 64.

329 "we should not forget that Raphael himself avoided giving the motif a naturalistic context". EBERLEIN, J. "The Curtain in Raphael's Sistine Madonna”, p. 70.

330 "the cortina motif (...) was the formal expression of the ceremonial concealment of late antique and Byzantine rulers, who, in imitation of the model provided by the ancient Eastern Great King, were in real life removed from the view of their subjects by curtains. The cortina motif originally appeared in pictorial art with, and because of, this meaning, and thence (...) the area of its application soon widened. (...) The essential meaning of the motif changed in Carolingian art. (...) now in place of the ruler it is the Evangelist who sits beneath the cortinae. (...) The motif derived its new meaning from the symbolic interpretation of the curtain hung before the Old Testament Holy of Holies in the tabernacle of the temple (...). The arrangement allows images to express a teaching central to medieval thought, revelatio, the possibility of perceiving the truth, the sensus spiritualis, behind all things. / When the veneration of the Virgin increased, the cortina motif entered Marian iconography. Again the change in content was important, but, unlike the first, this one should be seen as no more than a shift in accent [my highlights]". EBERLEIN, J. "The Curtain in Raphael's Sistine Madonna", p. 67-68.

${ }^{331}$ EBERLEIN, J. "The Curtain in Raphael's Sistine Madonna", p. 72.

332 There is another reason for the dual personification of Saint Sixtus. According to Eberlein, "After the acquisition of Piacenza by the Church in 1512, Julius may have ordered the work for the remodeled abbey church of S. Sisto (...). Julius II could have been identified as the second founder, alongside Saint Sixtus who was revered as the founder both of the city and the abbey. The saint's gesture of presentation in the Sistine Madonna would thus refer to the newly won city and its people". In: EBERLEIN, J. “The Curtain in Raphael's Sistine Madonna”, p. 75.
} 
IV, his uncle, as a model. The painting was commissioned in honor to his Rovere relative. It is interesting to note that Pope Sixtus IV founded the Feast of the Immaculate Conception of Mary, which "does not refer in the literal sense to the beginning of Mary's existence. It encompasses as well her role at the Incarnation of Christ" ${ }^{333}$. The relevance of the curtains ${ }^{334}$ to the images of the Madonna ${ }^{335}$ used to be due to this role at the Incarnation as habitaculum Dei, as temple of the spirit ${ }^{336}$. This dwelling is a reminder of the truth that traverses all things ${ }^{337}$ and which dwelled in glory in that womb. Eberlein concludes that "as the application of the Rovere emblem to Saint Sixtus indicates, the analysis of the curtain must also account for a specific, historical development connected with Sixtus IV, the content of which must be related to the meaning applied to the motif at that time" 338 .

Among the many interpretations available for the role the curtain might have played in the Sistine Madonna, this one which conciliates the general significance of the motif and the historical connections is the one defended by Eberlein. In his article dedicated to this issue, he lists several other alternatives that have been suggested as ways to understand the role of the curtain as: window curtain, theater curtain and tomb curtain, to name just a few. The tomb curtain interpretation proposed by Grimme, for example, has been very well accepted.

New and surprising, this idea linked the curtain in the painting to external, historical phenomena, and because of the large number of problems it solved, has (...) become the most successful of all interpretations. Among the many scholars who have endorsed it is H. von Einem, who repeated Grimme's idea with further

\footnotetext{
${ }^{333}$ EBERLEIN, J. “The Curtain in Raphael's Sistine Madonna”, p. 73.

334 "sometimes instead of a curtain only a cloth is shown over and around Mary, arranged so that it focuses attention on her womb". EBERLEIN, J. "The Curtain in Raphael's Sistine Madonna", p. 68.

335 Not only the Pope seems to be related to Mary's motherhood character, Saint Barbara also seems to have a connection to this subject. During her submission to torture, Saint Barbara had her breasts cutted. They are usually associated to motherhood. In the Sistine Madonna, Barbara appears with her hand on her breast.

${ }^{336}$ Later "the curtain motif was (...) transferred to Christological themes, a logical evolution from its meaning, when associated with Mary, of referring to her role in the Incarnation. In this new development, a central concept was the offer of the Redeemer's flesh as sacrifice, the "velamen, id est caro Christi" ["through the curtain, that is to say, his body"] (Hebr. 10:20)". (EBERLEIN, J. "The Curtain in Raphael's Sistine Madonna", p. 75.) The full statement declares: "In other words, brothers, through the blood of Jesus we have the right to enter the sanctuary, by a new way which he has opened for us, a living opening through the curtain, that is to say, his body". See: Hebr. 10: 19-21.

${ }^{337}$ See note 325 : "the possibility of perceiving the truth, the sensus spiritualis, behind all things".

${ }^{338}$ EBERLEIN, J. “The Curtain in Raphael's Sistine Madonna”, p. 75.
} 
arguments. The essential basis of the comparison is the type of tomb sculpture, widespread in Italy from the thirteenth century on, which depicts the deceased lying on a couch. The body, as was customary for centuries, is enclosed behind a curtain $^{339}$.

Nevertheless, it end up being criticized, since it is hard to find a bed or a deceased in Raphael's painting. According to Eberlein,

The tomb-curtain theory can point to the genuine formal analogy with the curtains on tomb monuments, but this does not transfer to the Sistine Madonna the significance as a bed-curtain which the Middle Ages and Renaissance clearly attached to the draperies carved on tombs ${ }^{340}$.

He also indicates as an issue the difficulty of this interpretation to explain the portrayal of Saint Sixtus with the features of Julius II. Eberlein finds hard to understand what would mean Julius II to be "presenting himself". Due to these reasons, he does not endorse this interpretation.

Grimme's defends that the Sistine Madonna was commissioned for the funeral ceremony of Pope Julius II $^{341}$. Benjamin refers to Grimme's theory saying: "On that occasion, Raphael's picture had been hung in a niche-like area toward the back of the chapel, and positioned just above the coffin" 342 . Following this interpretation, what Raphael portrays, Benjamin continues, is "the cloud-borne Madonna approaching the papal coffin $\left[{ }^{343}\right]$ from the rear of the niche, which was

\footnotetext{
339 EBERLEIN, J. "The curtain in Raphael's Sistine Madonna", p. 65.

${ }^{340}$ EBERLEIN, J. "The curtain in Raphael's Sistine Madonna", p. 65.

${ }^{341}$ As already mentioned in one of the first notes of introduction, since the tomb ordered from Michelangelo was not ready by the pope's death, the Madonna was temporarily installed at the choir chapel of St. Sixtus in St. Peter's.

${ }^{342}$ BENJAMIN, W. "The work of art in the age of its technological reproducibility: third version", p. 274. Original: "Auf dem Sarge ruhend war, im nischenartigen Hintergrunde dieser Kapelle, bei der feierlichen Aufbahrung Raffaels Bild angebracht worden". BENJAMIN, W. Gesammelte Schriften I, p. 483.

${ }^{343}$ The quote starts by wandering "what is the purpose of the molding (...) that the two cupids are leaning on?" (BENJAMIN, W. "The work of art in the age of its technological reproducibility: third version", p. 274). Then it is suggested that the Madonna is approaching the coffin. Does it also mean that it is being suggested that the wood base refers to the coffin? If it is so, this seems to bring important implications for her placement above the altar. One of them, for example, would be related to what happens at the altar, that is: the memory of the sacrifice that took place at the cross, which might be seen as a vertical coffin. At Raphael's painting, the position of Mary, the two cherubus and the two saints also evokes the shape of a cross. Nevertheless, these are just speculations.
} 
framed by green drapes" ${ }^{344}$. Benjamin also tells that the painting reallocation to the Church in Piacenza is justified by Grimme as

a result of Roman Catholic doctrine, which stipulates that paintings exhibited at funeral services cannot be used as objects of worship on the high altar. The rule meant that Raphael's picture had declined in value; but in order to obtain a satisfactory price for the work, the Papal See decided to facilitate the sale by tacitly tolerating display of the picture above the high altar. To avoid attracting undue attention, the painting was turned over to the monks in that far-off provincial town $^{345}$.

It is contentious the motivation for the commission of the painting. Heidegger's student, Putscher, for example, defends that the painting has always been intended to the high altar of a church in Piacenza ${ }^{346}$. Eberlein believes that Grimme's suggestion that the painting was commissioned for the funeral ceremony is "undemonstrable" 347 . In contrast, Benjamin and Lacoue-Labarthe seem to give credit to Grimme's suggestion ${ }^{348}$.

In this context, it is interesting to hear Heidegger's poem Loneliness $(\text { Eisamkeit })^{349}$. It sings:

Cloudy green light floats around the books $\left[{ }^{350}\right]$

${ }^{344}$ BENJAMIN, W. "The work of art in the age of its technological reproducibility: third version", p. 274. Original: "wie aus dem Hintergrunde der mit grünen Portieren abgegrenzten Nische die Madonna sich in Wolken dem päpstlichen Sarge nähert". BENJAMIN, W. Gesammelte Schriften I, p. 483.

${ }^{345}$ BENJAMIN, W. "The work of art in the age of its technological reproducibility: third version", p. 274. Original: "Der Grund (...) liegt im römischen Ritual. Das römische Ritual untersagt, Bilder, die bei Bestattungsfeierlichkeiten ausgestellt worden sind, dem Kult auf dem Hochaltar zuzuführen. Raffaels Werk war durch diese Vorschrift in gewissen Grenzen entwertet. Um dennoch einen entsprechenden Preis dafür zu erzielen, emschloß sich die Kurie, ihre stillschweigende Duldung des Bilds auf dem Hochaltar in den Kauf zu geben. Um Aufsehen zu vermeiden, ließ man das Bild an die Bruderschaft der entlegenen Provinzstadt gehen". BENJAMIN, W. Gesammelte Schriften I, p. 483.

${ }^{346}$ See BORGES-DUARTE, I. A arte como epifania, p. 59.

${ }^{347}$ EBERLEIN, J. "The curtain in Raphael's Sistine Madonna", p. 65.

${ }^{348}$ Heidegger says that the Sistine Madonna belongs to a church in Piacenza. But he also says that he does not mean it in the sense of an antiquarian. Since I will discuss this in the next chapter, I won't bring this element in this moment.

${ }^{349}$ Eisamkeit might also mean emptiness. For more on "eisam", see GA 12 [266], p. 254. "Im Einsamen west dagegen gerade der Fehl des Gemeinsamen als der bindendste Bezug $z u$ diesem $>>$ Sam $<<$ ist das gotische sama, das griechische $\alpha \mu \alpha$. Einsam besagt: das Selbe im Einigenden des Zueinandergehörenden". Translation: "But it is precisely the absence in the lonesome of something in common which persists as the most binding bond with it. The "some" in lonesome is the Gothic sama, the Greek hama, and the English same. "Lonesome" means: the same in what unites that which belongs together". In: "The way to language", p. 134. 
Outside, angels spread shrouds of death

It's snowing $\left[{ }^{351}\right]^{352}$.

Eberlein was looking for a bed and Heidegger himself helps us to find one. Once again, he says "Outside, angels spread shrouds of death". With this description, it become easier to see Mary, in the Sistine Madonna, surrounded by shrouds of death made of angel faces. Outside, she, who has already been associated to the deceased as the one who is apart ${ }^{353}$, now appears again as a deceased through a new and unexpected light. The missing elements, the bed and the deceased, might be fulfilled, if there were more support to this line of thought. Is there?

Let's remember that Mary is also called the Mystical Rose. Sallis calls attention to Guo Xi advice on how to paint, for example, a flower. The Chinese painter teaches: "To learn to paint a flower, it is best to place the blossoming plant in a deep hole in the ground and look down upon it" ${ }^{\text {"354 }}$. According to Sallis, "What the passage thus brings out is the Chinese artist's concern with shadows and with the blurring and obscuring aspects of the spectacle"355. What would mean then to lay Mary in this strange death bed? What would this have to do with the mutual belonging of concealment and unconcealment and with the "obscuring aspects of the spectacle"?

According to the Dictionary of Greek and Roman Antiquities, imago used to denote "the ancestral likeness which were exhibited" to public in a "Roman noble's dwelling" or in funerals ${ }^{356}$. It was not intended, however, to immortalize the features of the dead. Image use to signify "the portrait-mask in wax", whose origin was related to "the ancient beliefs connected with (...) the life of the dead

\footnotetext{
${ }^{350}$ It might be interesting to bring here one of the suggested interpretations for the Sistine's curtains. According to Eberlein, "theologians (...) have proposed to identify the [Sistine's] curtain, pulled back on both sides, as an allusion to the veil before the Old Testament Holy of Holies". EBERLEIN, J. "The curtain in Raphael's Sistine Madonna", p. 65.

${ }^{351}$ It is also snowing outside the window in Trakl's poem Ein Winterabend, which was previously quoted here.

${ }^{352}$ From 1916. Original: "Mattgrünes Licht schwimmt um die Bücher, / Engel breiten draußen Leichentücher. /

Es schneit". GA 16, p. 40.

${ }^{353} \mathrm{It}$ is worth remembering that to be apart is to make room, to empty oneself.

${ }^{354}$ Apud SALLIS, J. "Effacements of form", p. 646.

${ }^{355}$ SALLIS, J. "Effacements of form", p. 646.

${ }^{356}$ SMITH, W.; WAYTE, W.; MARINDIN, G. E. A Dictionary of Greek and Roman Antiquities. See "imago" entry.
} 
[my highlight]" 357 . Its assigned use in funeral ceremonies was also verified in other ancient traditions as the Egyptian ${ }^{358}$. The Roman images use to cover the face of the dead ${ }^{359}$ in a similar way the portrait-head of the mummies does. The images of ancestors could also be "part of the funeral procession" "360.

According to Grimme, the Sistine Madonna was set above Pope Julius II $\operatorname{coffin}^{361}$. As part of the funeral, we might say that the image played a part as a kind of mortuary portrait. The question rises again: if such masks or images used to portray the face of the dead, where is the dead $?^{362}$ Or why is there a Madonna? Let's pay attention that the role of such masks was not to immortalize the features of the dead. Rather, they were related to the life of the dead. The mask is the image of the dead as the presence of the absent ${ }^{363}$. It evokes the appearing of the unapparent. It was a reminding that everything is an image, a reminding through the image of the withdrawal of that which appears. In this sense, we could say that such portraits were an image of the image. They bring into emergence the memory of the bringing into emergence.

Lacoue-Labarthe reading interprets the Bild that the Sistine Madonna is as a true likeness (vraie semblance). Raphael's painting is, he says,

literally a por-trait: in Italian ritratto, with-draw [re-trait] (as in to re-draw [retrace, retrace]). In semblance, as it was still said in the Renaissance period, not of nothing (...), but of truth itself. (...) the mimesis, before all imitation: that which, in lack of a better alternative, I resigned myself to call $<<$ originary mímesis $>>364$.

\footnotetext{
357 SMITH, W.; WAYTE, W.; MARINDIN, G. E. A Dictionary of Greek and Roman Antiquities. See "imago" entry.

${ }^{358}$ Belting gives an example: "A mummy portrait such as that of a young woman (Louvre) has many features in common with an eleventh-century icon of Philip the Apostle and thus allow for unexpected comparisons, despite the gap in time and despite the difference in function, the former being a pagan portrait and the latter a Byzantine icon”. BELTING, H. Likeness and presence, p. 78 .

359 "For this purpose the services of an embalmer (pollinctor) were required; and it is a probable supposition that the services of the pollinctor did not end with preparing the body for burial, but that he also fashioned the mask that was to be buried with it [or burnt]. (...) they were faces in relief (expressi cera vultus) which received the colours and touches of nature". SMITH, W.; WAYTE, W.; MARINDIN, G. E. A Dictionary of Greek and Roman Antiquities. See "imago" entry.

360 SMITH, W.; WAYTE, W.; MARINDIN, G. E. A Dictionary of Greek and Roman Antiquities. See "imago" entry.

361 According to Eberlein, Grimme designates "the entire painting as a 'death-veil' ('Totenvelum')". EBERLEIN, J. “The curtain in Raphael's Sistine Madonna”, p. 65.

362 This might be a clue for why the Pope has Julius II features.

${ }^{363}$ See NANCY, J. Le regard du portrait, p. 53-54.

${ }^{364}$ LACOUE-LABARTHE, J. La vraie semblance, p. 68-70. Original: "littéralement un por-trait: en italien ritratto, re-trait (comme dans $<<$ retrace $>>$ ). À la semblance, comme on disait encore à
} 
As originary mimesis, the Sistine Madonna is a true likeness of truth, a portrait of the mutual belonging of concealment and unconcealment. Mary is the one who is apart as the one who makes room to a glorious shine. She is the deceased as the habitalucum Dei. The Sistine is an originary image (Bild) as a bringing into emergence the unapparent incessant rise of physis. This is what brings this image (Bild) close to the sense of icon that Heidegger indicates: to step back before something to let it come forth. To let the unapparent appearing shine is to let the bringing into emergence of the mutual belonging of concealment and unconcealment shine as incessant rise. According to Belting, "the icon is, in short, clearly the heir of the portrait of the ancients" 365 .

In the Church tradition, the well-known story about the Veronica veil tells us that when Jesus was carrying the cross to the Golgotha a woman saw Him and was moved with piety. She borrowed Him her veil to wipe His forehead. He held it to His face, which became miraculous impressed on the veil. The Veronica veil is a portrait of the living God. It is a portrait of the countenance of the Man-God, a portrait of the person of Christ. Veronica came to be linked to vera icon ${ }^{366}$, which means true icon or true image. As mentioned, Lacoue-Labarthe interprets the Sistine Madonna as a true likeness (vraie semblance) of truth. He suggests this understanding following Heidegger's characterization of the Bild as close to the sense of icon. According to Heidegger, in this originary image (Bild), "it happens the appearing of the becoming man [Menschwerdung] of God"367. Heidegger also associates Bild to Antlitz, that is: "image" to "face" or, in more appropriated terms, the bringing into emergence to countenance. Once the Veronica veil brings

l'époque de la Renaissance, non pas de rien (...), mais de la vérité ele-même. (...) la mimèsis, avant toute imitation: ce que, faute de mieux, je me suis resigne à nommer $<<$ mimèsis originaire $>>$ ".

${ }^{365}$ BELTING, H. Likeness and presence, p. 78.

366 There is also a Greek root, $\phi \varepsilon \rho о v \imath \kappa \eta$, that associates it to $\phi \varepsilon \rho \varepsilon \imath v$, to bring, and $v \imath \kappa \eta$, victory, that is: the one who brings victory. The immaculate Mother of God is also called a "Madonna della Vittoria". According to Eberlein, the Sistine Madonna has been associated not only to the Marian relation to victory, but also to the papal territorial victories. The victory of Ravena was particulary relevant, since it acquired Piacenza to Church's possession. Borge-Duarte also tells that the Madonna is close to the figure of ancient Nikes in the Church. See Arte como Epifania, p. 59. It is also worth mentioning again the crowning of the Madonna by two angels in figure 6 of the appendix.

${ }^{367}$ Which might also be related to the person of Christ. The word Menschwerdung might also be translated as Incarnation. Original: "geschieht das Scheinen der Menschwerdung Gottes". GA 13, p. 121 . 
all these elements together, it becomes an elegant support to Lacoue-Labarthe's interpretation of the Sistine Madonna as a vraie semblance.

As it was already specified, Heidegger says that image (Bild) means countenance (Antlitz). This remark gains new dimensions in the context of the mortuary mask. Countenance (Antlitz) might be associated to the Greek prósopon ${ }^{368}$. They both seem to have a common route that relates them to "what is in front of the eyes (of someone else)"369. Prósopon can also mean face, mask, character or person, which is associated to the meaning of persona ${ }^{370}$. Since persona literally means a sounding through, per sonare, countenance (Antlitz) could be thought then as that which let sound through itself. The meaning is related to the voice that sounds through the theatrical mask, for example. The mask appears and let sound through itself. It is the memory of the person as a per sonare.

It is also interesting to notice the use of the word 'person' on the study of the person of Jesus. In Christology, it refers to the investigation of the human and divine natures of Christ as co-existing in His person. Again, the sense of persona as a sounding through seems to be associated to the ambivalence of that which appears and that which sounds through. The Veronica veil as a portrait of the person of Christ might be thought in this light. It addresses this twofold once this veil is also a true icon. As discussed, for Heidegger, the icon is related to the originary sense of image (Bild) as a bringing into emergence the mutual belonging of concealment and unconcealment.

Heidegger designates his use of countenance (Antlitz) as an Entgegenblick as arrival, that is: as a glimpse toward (Entgegenblick) an unapparent appearing, which also unapparent appears in the shine in brilliance of the letting shine. It enowns itself, that is why it is also an "en-countering look"371 (Entgegenblick). This arrival refers to the incessant rise of physis, which is inapparently placed before the eyes, sounding through things. As the arrival of the mutual belonging of concealment and unconcealment, the mutual bringing of Mother and Son is

\footnotetext{
${ }^{368}$ It is possible to trace a similar route between the German Antlitz and the the Greek prósopon. See CHANTRAINE, P. Dictionnaire Etymologique Grec, p. 942. There is a direct reference to Antlitz in the entry 'prósopon'.

${ }^{369}$ My translation. Original: "ce qui est face aux yeux (d'autrui)". See CHANTRAINE, P. Dictionnaire Etymologique Grec, p. 942.

370 "personne (aussi au sens grammatical qui remonte à l'antiquité tardive)". See CHANTRAINE, P. Dictionnaire Etymologique Grec, p. 942.

${ }^{371}$ Radloff suggestion of translation for Entgegenblick.
} 
placed before the image forming a window, also an unapparent appearing as the openness of a disclosure. The association of countenance (Antlitz) and of prosópon to a placing before the eyes leads us to the Heideggerian notion of Ereignis $^{372}$, which might also be related to a placing before the eyes. According to Hofstadter, Heidegger makes use

of the 'own' meaning of 'eigen' to read the sense of the verb ereignen as to make one's own, to appropriate. (...) But (...) The verb ereignen was not in historical fact constructed out of the prefix er- and the adjective eigen, own. There was an earlier verb eräugnen, to place before the eyes, to show, connected with the noun Auge for eye. Some pronunciations sound $\ddot{a} u$ like $e i$, and so it became natural to sound the word as ereignen and thereupon to read its meaning accordingly ${ }^{373}$.

The placing before the eyes is related then to an appropriation of one's own. Heidegger's employment of Ereignis ${ }^{374}$ refers to a belonging together, a "mutual appropriation [that] becomes the very process by which the emergence into the light and clearing occurs" 375 .

The openness to such glance toward as arrival is an openness to a sounding through. "This opening up is the happening of unconcealment. This is nothing other than the happening of uncanniness" ${ }^{\text {"376 }}$. It is only possible to let it happen, to glimpse the unapparent mutual belonging, once one authentically mirrors it, that is once one authentically let it shine through itself, letting it enown itself. To step back before the incessant rise in order to let it come forth is to let it authentically face itself. Through Mary, it happens "the appropriating showing which disregards precisely itself, in order to free that which is shown, to its authentic appearance" 377 . Mary rests in peace as the highest peak of the image ${ }^{378}$. She is the deceased as the one who opening up to a glance toward the incessant rise, rises

\footnotetext{
${ }^{372}$ Ereignis is an ordinary word in German and usually means event, happening.

${ }^{373}$ HOFSTADTER, A. "Introduction", p. xix-xx. In: HEIDEGGER, M. Poetry, language, thought.

${ }^{374}$ See "Bremen and Freiburg lectures", p. 117. "The word 'event' [Ereignis] is taken from ordinary language. To appropriate [Er-eignen] means originally to eye [eräugen], i.e., to catch sight of, to call into view, to take possession [an-eignen]". Original: "Das Wort Ereignis ist der gewachsenen Sprache entnommen. Er-eignen heißt ursprünglich: er-äugen, d. h. erblicken, im Blicken zu sich rufen, an-eignen". GA 79, p. 125.

${ }^{375}$ HOFSTADTER, A. "Introduction", p. xx. In: HEIDEGGER, M. Poetry, language, thought.

${ }^{376}$ IM 40 [127], p. 178. Original: "Diese Eröffnung ist das Geschehen der Unver-borgenheit. Diese ist nichts anderes als das Geschehnis der Unheimlichkeit". GA 40 [127], p. 176.

377 "The way to language", p. 131. Original: "das ereignende Zeigen, das gerade von sich absieht, um so das Gezeigte in das Eigene seines Erscheinens zu befreien”. GA [262], p. 251.

${ }^{378}$ See again the third epigraph of this chapter.
} 
together with it, in an authentic belonging. "When one is put out of the home in this way, the home first discloses itself as such" ${ }^{379}$.

Such glance toward is also then an

apprehension as taking up a position to receive the appearing of beings. As such, it is nothing other than setting out upon one's own, distinct way. (...) this de-cided setting-out upon the way to the Being of beings, moves humanity out of the homeliness of what is most directly nearby and what is usual ${ }^{380}$.

The mystery (Geheimnis), as already stated, is the mystery of the mutual belonging of concealment and unconcealment in a thing. It is also the mystery of the mutual belonging of the uncanny and the familiar as the mutual belonging of the unhabitual and the habitual. One's opening to this mystery is an opening to a sheltering. For Heidegger, "to shelter means to ensconce (in der Hut behalten) the ownmost, wherein the ownmost remains only when it is allowed to return to itself [Rück-kehr] and rest in itself" ${ }^{381}$. The return to itself (Rückkehr) is a return home (Heimkehr), once it is a turn to one's ownmost. The home-land (Heimat) is where lies one's ownmost. To investigate how this belonging to one's ownmost has a singular character that assigns authenticity to a place making it emerge as a site will be next chapter's task.

\footnotetext{
379 IM [127], p. 178. Original: "In solcher Heraussetzung aus dem Heimischen erschließt sich das Heimische erst als ein solches". GA 40 [128], p. 176.

380 IM [128], p. 179. Original: "Vernehmung ist als das früher gekennzeichnete Be-ziehen einer Aufnahme-Stellung für das Erscheinen des Seien-den nichts anderes als ein eigenes Ausrücken auf einen ausge-zeichneten Weg. (...) so ent-schiedenen Ausrückens auf den Weg zum Sein des Seienden rückt den Menschen aus dem Heimischen des gerade Nächsten und Üblichen heraus". GA 40 [128], p. 177.

${ }^{381}$ Poverty, p. 7. Original: "Behüten (...) ist: das Wesen in der Hut behalten, worin es nur bleibt, wenn es in der Rückkehr zum eigenen Wesen beruhen darf". GA 73, p. 878.
} 


\section{3 \\ The Bild as Altar-Bild}

['August is alone in the high mountains'.]

He sits here between his ears and hears true emptiness. (...) Here - nothing meets nothing and is not there, there is not even a hole ${ }^{382}$.

Knut Hamsun

Perhaps, thinking, too, is just something like building a shrine ${ }^{383}$.

Martin Heidegger

They indeed may sound forth words, but they can not give Spirit. Most beautifully do they speak, but if thou be silent, they can not inflame the heart.

They teach the letter, but thou openest the sense. (...) thou impartest understanding to the hearing ${ }^{384}$.

Thomas de Kempis

In Rodin's sculpture, The Cathedral ${ }^{385}$, two hands carved in stone face each other. They are both right hands. This detail brings us again to the issue of a disclosure of appropriation (Ereignis). This time, the mirroring is a mirroring of hands, which builds a temple, a cathedral. We have proposed that the singularity of the Sistine Madonna is, for Heidegger, related to a kind of face to face of Being to itself that happens in this Bild, that is: an enowning (Ereignis) of Being, what is

\footnotetext{
${ }^{382}$ Apud Heidegger. IM [20-21], p. 29. Original: “August ist (...) einsam oben im Hochgebirge. (...) >> Er sitzt hier mitten zwischen seinen Ohren und Hört die wahre Leere. (...) Hier - triffft Nichts auf Nichts und ist nicht da, ist nicht einmal ein Loch (...)<<". GA 40 [20-21], p. 29.

${ }^{383}$ Translation modified. What is called thinking, p. 16. I have substituted "cabinet" by 'shrine' [Schrein], which might also mean ark. This ambiguity is important, since Rodin's Cathedral was previously called Ark of the covenant, which might also refer to Mary. Original: "Vielleicht ist das Denken auch nur dergleichen wie das Bauen an einem Schrein". GA 8, p. 18.

${ }^{384}$ KEMPIS, T. The Imitation of Christ, p. 151-152. Original: "Possunt quidem verba sonare, sed spiritum non conferunt. Pulcherrime dicunt, sed te tacente cor non accedunt. Litteras tradunt, sed tu sensum aperis. (...) tu auditui intelligentiam tribuis". In: KEMPIS, T. Imitatione Christi, III, 2, 2 .

${ }^{385}$ Figure 4 - next page. There is not even a hole, because what is seen is unapparent (unscheinbar).
} 


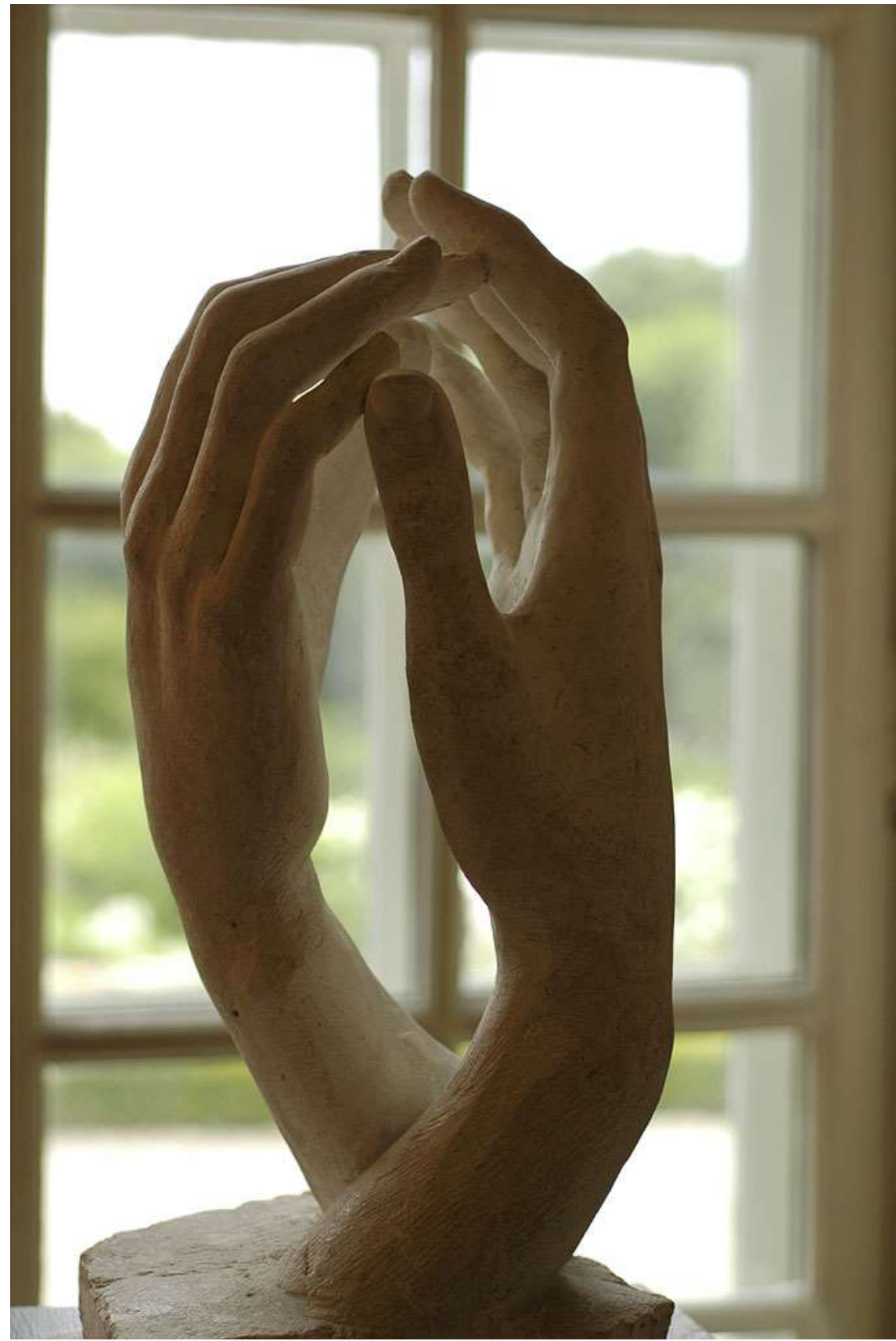

Figure 4

Auguste Rodin - The Cathedral - 1908

Rodin Museum, Paris 
a pleonasm. Rodin's sculpture helps us to address another important aspect related to this disclosure of appropriation: the belonging to a site (Ort). According to Heidegger, the Sistine belongs to a Church in Piacenza ${ }^{386}$ and this Church belongs to this image. They belong together.

In order to think deeper these belongings, let's remember that Heidegger says that "the site is always an altar" ${ }^{\prime 37}$. In its authentic essencing, the Sistine is a $\operatorname{site}^{388}$. It is also an $\operatorname{altar}^{389}$. But Heidegger's sentence continues: "the site is always an altar in a Church [my highlight] ${ }^{\prime 390}$. The altar is a site within a site, a Church $^{391}$. So, when we speak of the mutual belonging of the image to a Church and of a Church to the image, we are also talking about a mutual belonging of two sites, namely: the altar and the Church.

The singularity of the relation of mutual belonging of these two sites is related to the singularity of the Sistine as Bild. Heidegger declares: "To the singular [einzigen] event of the image necessarily corresponds $\left[{ }^{392}\right]$ its singularizing [Vereinzelung] $]^{393}$ in the unapparent [unscheinbaren] site [Ort $]$ of a Church among many others [my highlights]"394. The Sistine is explicitly said to be an Altar-Bild. It is not, however, an Altar-Bild merely in the sense of a painting that hangs at an altar, an altarpiece. Heidegger intends a more profound meaning, one that singularizes this image as an originary Bild. The unapparent character of the site is a relevant aspect in this consideration ${ }^{395}$. It helps us to understand how the Bild is itself an altar.

\footnotetext{
${ }^{386}$ For pictures of this Church, see the appendix, figures 9 to 14 . They also indicate the resemblance between San Sisto Church and Raphael's School of Athens.

${ }^{387}$ Original: "Der Ort is je ein Altar". GA 13, p. 121.

${ }^{388}$ Heidegger says: "The image is the appearing (...) of the site"; "The image forms the site". My translation of: "Das Bild ist das Scheinen (...) des Ortes"; "bildet das Bild den Ort". GA 13, p. 121.

389 "It [the image] is an Altar-Bild". My translation of: "Es [das Bild] ist Altar-Bild". GA 13, p. 120.

${ }^{390}$ Original: "Der Ort is je ein Altar einer Kirche [my highlight]". GA 13, p. 121.

${ }^{391}$ Someone could argue whether the Church is also a site (Ort). I hope that it will become evident along the text that as a temple the Church is also a site $(\mathrm{Ort})$.

392 This correspondence might also be understood as a belonging.

${ }^{393}$ The translation by cognates of singular of the parallelism between einzigen and Vereinzelung was inspired in the Spanish translation available in Experiencias del pensar (1910-1976).

${ }^{394}$ My translation. Original: "Dem einzigen Geschehnis des Bildes entspricht notwendig seine Vereinzelung an den unscheinbaren Ort der einen unter den vielen anderen Kirchen". GA 13, p. 121.

${ }^{395}$ For a reference on Heidegger's use of 'unscheinbaren', see ZIEGLER, S. "Matter Schein: Zu Heideggers Phänomenologie des Unscheibaren”, p. 97-108. In: Heidegger Studies, volume 30, 2014. See also GA 15 translated as Four seminars.
} 
In Letter on 'Humanism', Heidegger also uses the expression an "unapparent site [unscheinbarer Ort]". It refers to the stove where Heraclitus warms itself. The German philosopher characterizes it as "a quite ordinary and inconspicuous [unscheinbarer] site" ${ }^{\text {396 }}$. Just after saying this, Heidegger makes a very curious reference to bread: "True enough, bread is baked here. But Heraclitus is not even busy baking at the stove" 397 . Heidegger does not develop this reference. We could wonder if there is any relation to the altar bread and if the baking could be related to a transformation similar to the one that happens in the altar. In any case, the context implies that it is not just the bread, or its baking, that is related to the gods, but also the ordinary act of warming itself. "For here too the gods are present" ${ }^{\prime 398}$, invites Heraclitus. With these words, Heidegger finds a way to reaffirm that the extraordinary dwells in the ordinary as the uncanny dwells in the habitual. The presencing presences itself in unconcealment ${ }^{399}$. It presences, however, inapparently.

In Heraclitus, Heidegger says that "the physis is the unapparent" ${ }^{\text {" }}$. The physis "is what does not appear [Unscheinbare] in every appearing" Nevertheless, it is important to stress that unapparent does not mean invisible. According to Heidegger, "The physis is not the invisible [ $\left.{ }^{402}\right]$. On the contrary, it is precisely that which is seen in an originary way, although, at first and for the most part, it is often what is never intrinsically visualized at all”403. According to Heidegger, the unapparent as the presencing of presence is not strictly visualized

\footnotetext{
${ }^{396}$ My translation. In Pathmarks, it is suggested another one: "surely a common and insignificant place", p. 270. Original: "ein recht alltäglicher und unscheinbarer Ort". GA 9 [186], p. 355.

${ }^{397}$ Pathmarks, p. 270. Original: "Allerdings wird hier das Brot gebacken. Aber Heraklit ist am Backofen nicht einmal mit dem Backen beschäftigt". GA 9 [186], p. 355.

${ }^{398}$ Heraclitus apud Heidegger. Pathmarks, p. 270. Original: "einai gàr kaì entauta teoús, >>Götter wesen auch hier an <<". GA 9 [186], p. 356.

${ }^{399}$ It is worth elucidating that "the presencing of presence" is Being itself as the "twofold of the two in their oneness" that is: the oneness of concealment and unconcealment. OWL, p. 30 Original: "Anwesen des Anwesenden, d. h. die Zwiefalt beider aus ihrer Einfalt". GA 12 [122] See also: Four seminars, p. 80. "Where and how does presence itself presences? / Answer: It presences in unconcealment". GA 15 [136-137].

${ }^{400}$ My translation. Original: "Das Phúsis ist die Unscheinbare”. GA 55, p. 142.

${ }^{401}$ My translation. Original: "ist in allem Erscheinenden das Unscheinbare". GA 55, p. 143.

${ }^{402}$ Despite saying that the physis is not the invisible, Heidegger does relate the physis in other passages to an invisible [Unsichtbare] character. What is stressed here is just that it is not something invisible. The physis appears and to realize its incessant rise is to see it as a whole, that is, its unapparent character as incessant appearing.

${ }^{403}$ My translation. Original: "Die phúsis ist nicht das Unsichtbare, sie ist im Gegenteil gerade das anfänglich Gesichtete, das obzwar zunächst und zumeist, ja oft überhaupt nie eigens Erblickte". GA 55, p. 142.
} 
precisely because it is always already being carried out in unconcealment. As he himself says:

The armonía of phúsis, the joint [Fügung], in which phúsis presences, is something afanés, that is, 'what does not come into objective appearance', not because there belongs to it a krúptestai in the mistaken sense of hiding itself, but because the phúsis as the pure rising is more open than any straightforward manifestation; therefore it rests and presences as the unapparent [Unscheinbare $]^{404}$.

The unconcealment shelters the rising of physis. Their belonging together as the mutual belonging of concealment and unconcealment is an unapparent shine. "In the inconspicuous [Unscheinbaren] of the rising lies the assurance that (...) it is continually presencing out of itself in the rising"

In order to see this unapparent, we need, as Heraclitus, to let the nearness to the fire warm us. If we let it act in us too, tune us, we might hear the logos and then say, in an homologein, that the one unifies all, that is: we might become altars. After all, what is the role of the altar? The following passage from the Bible might help us to understand the intimacy between the role of both the altar and the temple. It says:

\begin{abstract}
Alas for you, blind guides! You who say, 'If a man swears by the Temple, it has no force; but if a man swears by the gold of the Temple, he is bound.' Fools and blind! For which is of greater worth, the gold or the Temple that makes the gold sacred? Or else, 'If a man swears by the altar it has no force; but if a man swears by the offering that is on the altar, he is bound.' You blind men! For which is of greater worth, the offering or the altar that makes the offering sacred? Therefore, when a man swears by the altar he is swearing by that and by everything on it. And when a man swears by the Temple he is swearing by that and by the One who dwells in it [my highlights]..$^{406}$
\end{abstract}

Despite the restrictions considering the metaphysical approach Heidegger might have criticized in this quotation, it might still give us important clues. The aspect that I would like to highlight in this passage is that both the altar and the temple

${ }^{404}$ Marcia's translation, p. 155. Original: "Die armonía der phúsis, die Fügung, als welche die phúsis west, ist nicht etwa deshalb afanés, d. h. >> nicht in den gegenständlichen Vor-schein kommend $<<$, weil zu ihr das krúptestai gehört in dem mißdeuteten Sinn des Sichversteckens, sondern weil die phúsis als das reine Aufgehen offener ist als jedes geradehin Offenkundige; deshalb bleibt sie und west sie als das Unscheinbare". GA 55, p. 143.

${ }^{405}$ My translation, p. 157. Original: "Im Unscheinbaren des Aufgehens ruht die Gewähr, daß es (...) aus sich ohne Unterlaß im Aufgehen west”. GA 55, p. 144.

${ }^{406}$ Mt 23, 16-22. 
have the role of making sacred. This common function might be a way of understanding their mutual belonging ${ }^{407}$. They mirror a similar task. But how does the altar make sacred and how does the temple make sacred?

According to Heidegger, "In the Bild, as this Bild, it happens the appearing of the becoming man of God, it happens that transformation [Verwandlung], which enowns itself [sich ereignet] at the altar as transubstantiation [die Wandlung], as the ownmost of the sacrifice of the Mass [Meßopfers] [my highlights]" ${ }^{\prime 08}$. The stress of naming the Bild as this Bild refers to its singularity. As I have suggested, its unique character is related to a disclosure of appropriation (Ereignis). This enowning (Ereignis), the quote continues, happens as "the appearing of becoming man of God", or if we take consent, as the appearing of the coming into unconcealment of the incessant rise, that is an unapparent appearing in unconcealment of the mutual belonging of concealment and unconcealment. It is a bringing forth in appearing of the incessant rise, that is: an unapparent shining in unconcealment. As Heidegger says, "The image $[$ Bild $]$ (...) is nothing but the suddenness of this appearing" 409 . This extract indicates that the transformation mentioned on the previous quote, which I am trying to relate to a transformation of seeing (what I will soon develop further), might be understood as the appearance of the unapparent shining in a glimpse, in a lightning flash. This transformation is a making sacred as a making shine in brilliance. The transformation of seeing would then be one from opacity to brilliance, from not being tuned with the unapparent to suddenly having the evidence of such unapparent shine. This transformation "enowns itself". The making sacred is a transformation in which the unapparent enowns itself. As we have seen in the

\footnotetext{
${ }^{407}$ Another interpretation of the mirroring of the altar and the church that might be pursued would be one concerning the priest (at the altar) and the believers (as members of the Church, mystical body). The priest, in persona Christi, is responsible to perform the transubstantiation, a kind of Fiat, since the bread become the body of Christ. The Church, understood as the believers, has the task to imitate Christ. By doing His will, the Church says as Mary: Fiat. There would be a kind of face to face of Christ to himself as the priest (in persona Christi) and the members of the Church (imitators of Christ). Another kind of face to face would be the one of the two Fiats. We could also name the face to face of the body of Christ as sacred break in the altar and the body of Christ as Church, mystical body.

${ }^{408}$ My translation. Original: "Im Bild, als dieses Bild geschieht das Scheinen der Menschwerdung Gottes, geschieht jene Verwandlung, die auf dem altar als $>>$ die Wandlung $<<$, als das Eigenste des Meßopfers sich ereignet". GA 13, p. 121.

${ }^{409}$ My translation. Original: "das Bild (...) ist nicht anderes als die Jähe dieses Scheinens". GA 13, p. 120.
} 
previous chapter, what enowns itself is Being. This en-owning happens at the altar. It happens as transubstantiation.

In What are poets for?, Heidegger states that "The salvation must come from where there is a turn with mortals in their nature" 410 , or, we could say, from where there is an enowning of their ownmost. The salvation as a rescuing from inauthenticity must come from the disclosure of appropriation (Ereignis). To belong is to dwell in this enowning. "Belonging now means brought into ownership [vereignet], delivered into ownership [zugeeignet]"411. The en-owning (Er-eignis) might be thought as a transformation from inauthenticity (Uneigentlichkeit) to authenticity (Eigentlichkeit). Such distinction is related to the way something is related to such appropriation of its own (eigen). In Bremen and Freiburg lectures, Heidegger elucidates:

Who we humans authentically are and what being authentically is, we may first duly question and surmise only when thinking has entered that region where appropriation [Eignung], bringing into ownership [Vereignung], propriety [Eigentum], and authenticity [Eigentlichkeit] reign, namely, in the event of appropriation [Er-eignis $]^{412}$.

This distinction between inauthenticity and authenticity might be related to the distinction Heidegger makes between a location (Stelle) and a site (Ort). The locations (Stellen) would be inauthentic places and a site would be an authentic place. This way of formulating allows us to think the relation between a location (Stelle) and a site (Ort) through a transformation from inauthenticity to authenticity. I understand that this raises an issue. Would the Sistine Madonna then be able to be a site (Ort) somewhere else besides the Piacenza church? I mean this in the sense of: would it be possible that another location would be transformed so that it could shelter this Bild? This seems, at first sight, to be evidently against Heidegger's letter: "The Sistine belongs to a Church in

\footnotetext{
410 "What are poets for?", p. 115-116. Original: "Die Rettung muß von dort kommen, wo es sich mit den Sterblichen in ihrem Wesen wendet". GA 5 [273], p. 296.

${ }^{411}$ Bremen lectures, p. 118. Original: "Gehören heißt jetzt: vereignet, zugeeignet". GA 79, p. 126.

${ }^{412}$ Bremen lectures, p. 118. Original: "Wer wir Menschen eigentlich sind und was das Sein eigentlich ist, werden wir erst dann gebührend erfragen und vermuten dürfen, wenn das Denken in jenen Bereich eingekehrt ist, wo Eignung, Vereignung, Eigentum und Eigentlichkeit walten, nämlich im Er-eignis". GA 79, p. 126. This translation employs "event of appropriation" as equialent to Ereignis. Nevertheless, we must be careful with this use, since it is not something that takes place in a literally visible way, but that happens inaparrently. See Glossary.
} 
Piacenza"413. He even specifies his reference: to "a church among many others" ${ }^{\prime 414}$.

The Sistine, however, is itself an altar. It "determines by itself the site $[O r t]$ ". I believe this is very important to hightlight. From an aesthetical point of view, it is true, according to Heidegger, Hetzer's analysis that: the Sistine " $>>$ is not bound to a Church, [it] does not requires a specific location $<<^{\sharp 415}$. Although correct, it lacks "the authentic truth [der eigentlichen Wahrheit]"416, it lacks authenticity. We are brought back to the issue of a transformation. The Sistine used to be a Bildwesen, an essencing of the Bild. It still is, though, transformed. Transformed in the other way around: not from inauthenticity to authenticity, but from authenticity to inauthenticity. It cannot anymore, no matter where it finds itself, presence authentically, that is: "determine by itself a site" ${ }^{417}$. Let's keep in mind that the altar itself seems to make sacred, according to the former Bible's quote. So, when Heidegger says that the Sistine "has (...) lost its site" ${ }^{418}$, we might read that it has lost its altar character. It has lost authenticity.

According to Heidegger, we live in times of forgottenness of Being. The fact, he says, that the Sistine Madonna has become a work of art is inherent to a process of objectification. Let's remember that, for him, thinking is of being in a twofold way. It is Being that thinks and it thinks itself. But it is also Being thinking itself through human being.

the human essence belongs to the essence of beyng insofar as the essence of beyng needs the human essence, in accordance with its own essence, in order to remain guarded in the midst of beings as being, and thus needs it in order to essence as being ${ }^{419}$.

Once we live in times of opacity and inauthenticity, this transformation on the Sistine presencing is closely related to the rise of the subject. In such times, the human being is the subject who experiences art as an object and not the one who

\footnotetext{
${ }^{413}$ My translation. Original: "The Sixtina gehört in die eine Kirche zu Piacenza". GA 13, p. 120.

${ }^{414}$ My translation. Original: "der einen unter den vielen anderen Kirchen”. GA 13, p. 121.

${ }^{415}$ My translation. Original: " $>>$ nicht an eine Kirche gebunden sei, nicht nach einer bestimmten Austellung verlage $<<"$. GA 13, p. 120.

${ }^{416}$ GA 13, p. 120.

${ }^{417}$ My translation. Original: "diesen Ort selber zu bestimmen”. GA 13, p. 120.

${ }^{418}$ My translation. Original: "hat (...) seinen Ort verloren”. GA 13, p. 120.

${ }^{419}$ Bremen and Freiburg lectures, p. 65. Original: "zum Wesen des Seyns (...) das Menschenwesen gehört, insofern das Wesen des Seyns das Menschenwesen braucht, um als Sein nach dem eigenen Wesen inmitten des Seienden gewahrt zu bleiben und so als das Seyn zu wesen”. GA 79, p. 69.
} 
lets Being appear in its shine through art as techne, that is: as a bringing forth of Being in appearing. Closed, human being does not let itself be transformed by the work, he does not open itself to its ownmost. Works of art as objects, leveled in "the uniformity of exhibition [Austellung]"420, do not awake the uncanny, the strangeness of the habitual.

Nevertheless, the Sistine is also an altar in a Church. In order to understand this specification, let's hear Heidegger himself: "This church (...) that is: each one [my highlight]"421. It means: "each one, singular [einzelne] of its kind [my highlight]" 422 . Each one of its kind "calls for this unique window of this unique image [Bild] [my highlight]" 423 . In their singularity, each one calls for the unique character, the singular character, of this image (Bild). Each one calls for the character of enowning (Ereignis) of the image (Bild), because each place becomes a site through a disclosure of appropriation (Ereignis). It is this enowning that "grounds and consummates the building of the church"424. The church and each one of its kind means all churches in the sense of: all that is also a temple. Altars and temples long for fulfilling their function, that is: for making sacred.

I suggest understanding this making sacred as the gathering of the ownmost of things. As such gathering, it is also the appropriation of one's own as an enowning (Ereignis). According to Heidegger,

Originally the word "site" suggests a place in which everything comes together, is concentrated. The site gathers unto itself, supremely and in the extreme. Its gathering power penetrates and pervades everything. The site, the gathering power, gathers in and preserves all it has gathered, not like an encapsulating shell but rather by penetrating with its light all it has gathered, and only thus releasing it into its own nature [my highlights] $]^{425}$.

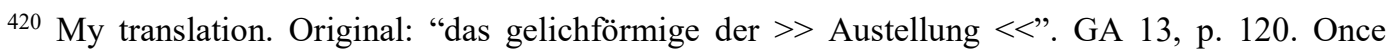
again, it is worth mentioning Duchamp's Fountain. See note 28.

${ }^{421}$ My translation. Original: "Diese Kirche (...) d. h. jede". GA 13, p. 121.

${ }^{422}$ My translation. Original: "jede einzigen ihrer Art". GA 13, p. 121.

${ }^{423}$ My translation. Original: "rufen nach dem einzigen Fenster dieses einzigen Bildes". GA 13, p. 121.

${ }^{424}$ My translation. Original: "gründet und vollendet den Bau der Kirche”. GA 13, p. 121.

425 "Language in the poem", p. 159-160. Original: "Ursprünglich bedeutet der Name $>>$ Ort $<<$ die Spitze des Speers. In ihr läuft alles zusammen. Der Ort versammelt zu sich ins Höchste und Äußerste. Das Versammelnde durchdringt und durchwest alles. Der Ort, das Versammelnde, holt zu sich ein, verwahrt das Eingeholte, aber nicht wie eine abschließende Kapsel, sondern so, daß er das Versammelte durchscheint und durchleuchtet und dadurch erst in sein Wesen entläßt”. GA 12 [37], p. 33.
} 
The Sistine, as openness of a disclosure, is a site. Nevertheless, it also needs human being, a temple, to authentically presences as Bild. Without a temple, the Sistine remains inauthentic. According to Heidegger, "Wherever this image [Bild] might still be situated [aufgestellt] in the future, it would have lost its site [Ort]. It would be denied to it to unfold in an originary way its own essence, that is to set by itself this site [Ort] [my highlights]" ${ }^{426}$. Even if it were returned to the church $^{427}$ in Piacenza? Wherever. Why? This indicates that it has been "transformed [verwandelt ${ }^{428}$ ] in its essence" ${ }^{429}$. It has been transformed, because we live in times of forgottenness. It has lost its world. According to Heidegger, "even when we try to cancel or avoid such displacement of the work - by, for example, visiting the temple at its site in Paestum or Bamberg cathedral in its square the world of the work that stands there has disintegrated" 430 .

Because the Sistine has lost its site in the sense of losing its temple, it has also lost its site as its authentic character as altar. Heidegger says that "The image [Bild] wanders in the alien [Fremde $]^{\prime 431}$. It is out of its originary place as out of its originary character. Nevertheless, as openness of a disclosure it also wanders in the alien [Fremde] as the uncanny, which "remains (...) unknown"432 to the museum kind of representation that is inspired by the subject and object relation. Heidegger plays with both meanings of Fremde: to be out of one's homeland, at a foreign place, and to be something strange, uncanny. As openness of a disclosure, the image longs for its authenticity.

The image (Bild) homesickness (Heimweh) is a longing for its ownmost. "As a work, it belongs uniquely [einzig] within the region it itself opens up. For the work-being of the work presences in and only $[$ nur] in such opening up. (...)

\footnotetext{
${ }^{426}$ My translation. Original: "Wo immer künftig dieses Bild noch $>>$ aufgestellt $<<$ sein mag, dort hat es seinen Ort verloren. Es bleibt ihm versagt, sein eigenes Wesen anfänglich zu entfalten, $d$. $h$. diesen Ort selber zu bestimmen”. GA 13, p. 120.

${ }^{427}$ San Sisto's Church.

${ }^{428}$ I am highlighting this word because of Heidegger's previous mentioned reference to "that transformation [Verwandlung], which enowns itself [sich ereignet] at the altar as transubstantiation [die Wandlung]". My translation. GA 13, p. 121.

${ }^{429}$ My translation. Original: "verwandelt in seinem Wesen". GA 13, p. 120.

${ }^{430}$ OWA, in Off the Beaten track, p. 20. Original: "auch wenn wir uns bemühen, solche Versetzungen der Werke aufzuheben oder zu vermeiden, indem wir z. B. den Tempel in Paestum an seinem Ort und den Bamberger Dom an seinem Platz aufsuchen, die Welt der vorhandenen Werke ist zerfallen". GA 5 [30], p. 26.

${ }^{431}$ My translation. Original: "Das Bild irrt (...) in der Fremde". GA 13, p. 120.

${ }^{432}$ My translation. Original: "bleibt (...) unbekannt”. GA 13, p. 120.
} 
in the work, the happening of truth is at work [my highlights]"433. A work's world is such a region it discloses. It opens it up in a lightning flash. Once lost, it is not possible to reverse it. Nevertheless, the work remains the possibility of making a world rise, that is: "to make the happening of truth in the work visible anew [my highlight]"434. In Introduction to metaphysics, Heidegger elucidates

this means nothing less than to repeat and retrieve (wieder-holen) the inception of our historical-spiritual Dasein, in order to transform it into the other inception. Such a thing is possible. It is in fact the definitive form of history, because it has its onset in a happening that grounds history. But an inception is not repeated when one shrinks back to it as something that once was, something that by now is familiar and is simply to be imitated, but rather when the inception is begun again more originally, and with all the strangeness, darkness, insecurity that a genuine inception brings with it ${ }^{435}$.

Such transformation from inauthenticity to authenticity is the coming forth of the unapparent in a brilliant shine, that is: to make the unapparent rise again in brilliance. It does not mean coming back to Piacenza, but to its ownmost as a new inception.

Once the work longs for its ownmost, for its being a site (Ort), "We would have to learn to recognize that things themselves are places and not merely belong in a place [my highlight]"436. As Lacoue-Labarthe calls attention: the image $i$ s the place precisely where $(\mathrm{am} \text { dem })^{437}$ "the sacrifice of the Mass [Meßopfer] is celebrated". The image as the "appearing of the time-space-play [das Scheinen des Zeit-Spiel-Raumes]"438 is the site. Thus, as the time-space-play is unapparent,

\footnotetext{
433 OWA, in Off the Beaten track, p. 20. Original: "Das Werk gehört als Werk einzig in den Bereich, der durch es selbst eröffnet wird. Denn das Werksein des Werkes west und west nur in solcher Eröffnung. (...) im Werk sei das Geschehnis der Wahrheit am Werke". GA 5 [30], p. 27.

${ }^{434}$ OWA, in Off the Beaten track, p. 20. Original: "das Geschehnis der Wahrheit im Werk erneut sichtbar zu machen". GA 5 [30], p. 27.

${ }^{435}$ IM [30], p. 41. Original: "das besagt nichts Geringeres als den Anfang unseres geschichtlichgeistigen Daseins wieder-holen, um ihn in den anderen Anfang zu verwandeln. Solches ist möglich. Es ist sogar die maßgebende Form der Geschichte, weil es im Grundgeschehnis ansetzt. Ein Anfang wird aber nicht wiederholt, indem man sich auf ihn als ein Vormaliges und nunmehr Bekanntes und lediglich Nachzumachendes zurückschraubt, sondern indem der Anfang ursprünglicher wiederangefangen wird, und zwar mit all dem Befremdlichen, Dunklen, Ungesicherten, das ein wahrhafter Anfang bei sich führt”. GA 40 [30], p. 42.

436 Art and space, p. 307. Original: "Wir müßten erkennen lernen, da $\beta$ die Dinge selbst die Orte sind und nicht nur an einen Ort gehören". GA 13, p. 208.

${ }^{437}$ Original: "an dem: à même lequel". LACOUE-LABARTHE, P. La vraie semblance, p. 55. It refers to Heidegger's passage "des Ortes, an dem das Meßopfer gefeiert wird [my highlight]". GA 13, p. 121. My translation: "the site, in which the sacrifice of the Mass is celebrated".

${ }^{438}$ GA 13, p. 121.
} 
the site is unapparent. It is the unapparent appearing of the incessant rise. Since the sacrifice of the Mass is celebrated is such site, it is then celebrated in the unapparent. It is a transformation of seeing as the seeing of the unapparent. It has already been mentioned in the previous chapter that Athena, as the meditating one, has her glance turned to the limit as "that on account of which something is gathered in its ownmost constitution" 439 . It is worth adding that, because she is also the one whose eye "shines and radiates [ist das glänzend-leuchtende]" 440 , the owl, $\eta \gamma \lambda \alpha \cup \xi^{441}$, is "attributed to her as a sign of her essence"442. According to Heidegger, "the owl's eye is not only fiery-blazing, but she can also see at night, making visible what is otherwise invisible [Unsichtbare]"443. As openness of a disclosure, the Sistine is a meditation on a limit. It is also the becoming man of God, which Heidegger says that arrives at the altar as transubstantiation in the sense, I suggest, of a transformation of seeing, which lets the unapparent appear in its brilliant shine.

Things are mysterious and long for their authentic presencing. They are ordinary and long for making the extraordinary shine through them. Heraclitus' stove is ordinary. It is an ordinary and unapparent site. Dwelling in the unapparent, the stove warms. Thus, there too "the gods are present". According to Heidegger, "the abode of the gods is the presencing of an insight, so that only in their glance and in what they perceive the being shines" ${ }^{\prime 44}$. Each thing also calls for this image, because all things, even inauthentically, even being opaque, are the rising of physis. Each thing is a call for letting this unapparent shine in brilliance. A poem ${ }^{445}$ by Joseph v. Eichendorff, which Heidegger quotes in Language and

439 "The provenance of art and the destination of thought", 120-121. Original: "jenes, wodurch etwas in sein Eigenes versammelt ist". GA 80. In: http://www.eudia.org/wp/download .php?id=1142, p. 5. It has already been quoted in the previous chapter.

440 "The provenance of art and the destination of thought", p. 120. GA 80 . http://www.eudia.org/wp/download.php?id=1142, p. 4.

${ }^{441}$ Heidegger also adds that "the adjective $\gamma \lambda \alpha \cup \kappa \circ \zeta$ denotes the brilliant lustre of the see, the stars, the moon, but also the shimmer of the olive tree". "The provenance of art", p. 120. Original: "Das Beiwort $\gamma \lambda \alpha \cup \kappa о \zeta$ nennt das strahlende Glänzen des Meeres, der Gestirne, des Mondes, aber auch den Schimmer des Ölbaumes". GA 80. http://www.eudia.org/wp/download.php?id=1142, p. 4.

442 "The provenance of art and the destination of thought", p. 120. Original: "gehört zu ihr als das Zeichen ihres Wesens". GA 80. http://www.eudia.org/wp/download.php?id=1142, p. 4.

443 "The provenance of art and the destination of thought", p. 120. Original: "Deren [die Eule] Auge ist nicht nur feurig-glühend, es blickt auch durch die Nacht hindurch und macht das sonst Unsichtbare sichtbar". GA 80. http://www.eudia.org/wp/download.php?id=1142, p. 4.

${ }^{444}$ My translation. "der Aufenthalt der Götter ist die Gegenwart der Hereinblickenden, so daß in deren Blick und dem von ihnen Er-blickten erst das Seiende erscheint". GA 55, p. 351.

${ }^{445}$ The poem is entitled Wünschelrute, divining rod. In Greek Mythology, the rod refers to the connection or communication between sky and earth. It is a symbol of a kind of bridge. 
homeland (Sprache und Heimat), synthetizes this mastery: "Sleeps a song in all things (...) / Just find the magic word / and the world will start to sing"446.

What is the magic word? Which is the word that makes sing? Poetry: it is a singing word. In it, the gathering of the ownmost of things echoes. The song needs a poet to emerge as the work needs a temple. What is needed is a poetic dwelling, an abide that gathers the ownmost of things. "Every great poet creates his poetry out of one single poetic statement only. The measure of his greatness is the extent to which he becomes so committed to that singleness that he is able to keep his poetic Saying wholly within it" ${ }^{\prime 47}$. Such poetic Saying is, nevertheless, nameless [Namenlosen] as the incessant rise of physis is unapparent. Eberlein calls attention to the angel on the left, in the Sistine Madonna, who "looking up at Mary and Christ, supports his head on his hand, in the familiar gesture of grief, and lays one finger over his mouth as though demanding silence" ${ }^{\not 48}$. The angel ${ }^{449}$ demands silence as demanding an inclination, a step back before the mutual bringing in order to let it shine. The poet and the temple are needed because the ownmost of things happens as a disclosure of appropriation. It can only take place through man, as the unapparent incessant rise needs appearing. As Heidegger says, "To sing, to say specifically worldly existence (...) means: to belong in the precinct of beings themselves. (...) this precinct is being itself ${ }^{\circ 450}$. Belonging to being, poets sing and "Their song sanctifies over the land [my highlight]"451.

\footnotetext{
${ }^{446}$ My translation. Original: "Schläft ein Lied in allen Dingen (...) / Und die Welt hebt an zu singen, / Triffst du nur das Zauberwort". GA 13, p. 159.

447 "Language in the poem", p. 160. Original: "Jeder große Dichter dichtet nur aus einem einzigen Gedicht. Die Größe bemißt sich daraus, inwieweit er diesem Einzigen so Anvertraut wird, daß er es vermag, sein dichtendes Sagen rein darin zu halten". GA 12 [37], p. 33.

${ }^{448}$ EBERLEIN, J. "The curtain in Raphael's Sistine Madonna", p. 72.

${ }^{449}$ In Why poets?, Heidegger refers to a "creature who manages the unheard center of the widest compass and lets it appear", a "creature already secure in the entirety of beings because it has already carried out the transformation of represented visibility into the invisibility of the heart". $\mathrm{He}$ says that Rilke calls this creature, in the Duino Elegies, the angel. Rilke says in a letter: "the angel of the elegies is that being who affirms the recognition of a higher rank of reality in the invisible". It is interesting to see angels characterized as children, since they might be interpreted as the new born ones as symbolizing the new birth inherent to the seeing of the unapparent. The new born ones are the spectators in the Sistine. (Original: "das Wesen, das die unerhörte Mitte des weitesten Umkreises verwaltet und erscheinen läßt”; "einem Wesen sagt, das im Ganzen des Seienden schon sicher ist, weil es die Verwandlung des vorgestellten Sichtbaren in das herzhafte Unsichtbare schon vollzogen hat", GA 5 [288], p. 312; Rilke Apud Heidegger: "Der Engel der Elegien ist das jenige Wesen, das dafür einsteht, im Unsichtbaren einen höheren Rang der Realität zu erkennen". GA 5 [288], p. 312).

450 "Why poets?", p. 237. Original: "Singen, eigens das weltische Dasein sagen (...) das bedeutet: in den Bezirk des Seienden selbst gehören. Dieser Bezirk ist (...) das Sein selber”. GA 5 [292], p. 316.

451 "Why poets?”, p. 240. Original: "Ihr Lied überm Land heiligt”. GA 5 [294], p. 319.
} 
This sanctification as a making sacred is again the gathering of the ownmost of things as a making them shine in brilliance. It "lets lie before us what lies before us as such and as a whole" ${ }^{, 452}$. In this context, it is worth recalling that Heidegger characterizes the image (Bild) as a bringing into emergence (her-vorbringing ${ }^{453}$ ) with the support of the meaning of icon. It is needed a step back before something in order to let an "en-countering look" (Entgegenblick) to happen. The poet lets the enowning happen by stepping back, by letting being emerge, appropriating itself. After all, being itself is the authentic precinct. Human being is a temple only by letting dwell in it the authentic precinct where the ownmost of things is gathered. Human being's poetic saying would be then a homo-logein in an interesting sense, since, as also a thinking, it would be Being listening and echoing Being. To say in a homo-logein would be to let Being say. As a gathering, the poetic saying can only echo such gathering, singing: One is all, "the unique one unifying all" $" 454$. But that is not what it says ${ }^{455}$, because this is nameless. It is the way [Weise] in which it says: sheltering.

According to Heidegger, "The work of art is work not primarily because it is worked, made, but because it puts Being to work in a being"456. It brings Being into emergence in a being.

Usually we take production [Hervorbringen] to be an activity whose performance has a result, the finished structure, as its consequence. It is possible to conceive of making [Hervorbringen] in that way; we thereby grasp something that is correct, and yet never touch its nature, which is a producing [Herbringen] that brings something forth [vorbringt]. For building brings the [gathering of the mutual belonging of concealment and unconcealment] (...) hither [here] [her] into a thing (...) and brings forth $[\mathrm{vor}]$ the thing as a location [Ort], out into what is already there $[$ Anwesende], room for which is $[i s t]$ only now made by $[$ durch $]$ this location $[$ Ort $][\text { my highlights }]^{457}$.

452 "Logos (Heraclitus, fragment B 50)", in EGT, p. 70. Original: "vorliegen läßt das Vorliegende als solches und im Ganzen”. GA 7 [212], p. 225.

${ }^{453}$ Which is also a bring forth here.

${ }^{454}$ Heraclitus Apud "Logos (Heraclitus, fragment B 50)", in EGT, p. 75. Original: "das EinzigEine einend Alles". GA 7 [218], p. 230.

${ }^{455}$ See "Logos (Heraclitus, fragment B 50)", in EGT, p. 70. GA 7 [212], p, 225.

${ }^{456}$ IM [122], p. 170. Original: "Das Werk der Kunst ist in erster Linie nicht Werk, sofern es gewirkt, gemacht ist, sondern weil es das Sein in einem Seienden er-wirkt". GA 40 [112], p. 168.

457 "Building Dwelling Thinking", p. 157. Original: "Gewöhnlich nehmen wir das Hervorbringen als eine Tätigkeit, deren Leistungen ein Ergebnis, den fertigen Bau, zur Folge haben. Man kann das Hervorbringen so vorstellen: Man faßt etwas Richtiges und trifft doch nie sein Wesen, das ein Herbringen ist, das vorbringt. Das Bauen bringt nämlich (...) her in ein Ding (...) und bringt das Ding als einen Ort v o $r$ in das schon Anwesende, das jetzt erst durch diesen Ort eingeräumt ist". GA 7 [154], p. 161. See Basic writings, p. 361. 
The site grants the unapparent appearing of the presencing. The thing as a site lets the presencing appear. Although already presencing, now it shines in brilliance.

In the end of this passage, Heidegger highlights the 'is'. Now, through the site, something authentically is. Something is finally granted as if for the first time. In Building Dwelling Thinking, the philosopher traces the close connection between the site as a dwelling place and this 'is' as an authentic being, dwelling. He says:

bauen, buan, bhu, beo are our word bin in the versions: ich bin, I am, du bist, you are, the imperative form bis, be. What then does ich bin mean? The old word bauen, to which the bin belongs, answers: ich bin, du bist mean: I dwell, you dwell. (...) The old word bauen, which says that man is insofar as he $d w e l l s$, this word bauen however also means at the same time to cherish and protect, to preserve and care for, specifically to till the soil, to cultivate the vine. Such building only takes care - it tends the growth that ripens into its fruit of its own accord. Building in the sense of preserving and nurturing is not making anything. Shipbuilding and temple-building, on the other hand, do in a certain way make their own works. Here building, in contrast with cultivating, is a constructing. Both modes of building - building as cultivating, Latin colere, cultura, and building as the raising up of edifices, aedificare - are comprised within genuine building, that is, dwelling ${ }^{458}$.

As already mentioned, it is enowning that "grounds and consummates the building [der Bau $]$ of the church" ${ }^{\prime 49}$. The call of the mystery of things is already there. "Profane spaces are always the privation of sacred spaces" 460 . As the primal call of language is only in oblivion, this mystery (Geheimnis) "merely falls silent. Man, though, fails to heed this silence" 461 . He fails to build in the sense of

\footnotetext{
458 "Building Dwelling Thinking", p. 145. Original: "Bauen, buan, bhu, beo ist nämlich unser Wort »bin« in den Wendungen: ich bin, du bist, die Imperativform bis, sei. Was heißt dann: ich bin? Das alte Wort bauen, zu dem das »bin« gehört, antwortet: »ich bin«, »du bist« besagt: ich wohne, du wohnst. (...) Das alte Wort bauen, das sagt, der Mensch sei, insofern er wohne, dieses Wort bauen bedeutet nun aber zugleich: hegen und pflegen, nämlich den Acker bauen, Reben bauen. Solches Bauen hütet nur, nämlich das Wachstum, das von sich aus seine Früchte zeitigt. Bauen im Sinne von hegen und pflegen ist kein Herstellen. Schiffsbau und Tempelbau dagegen stellen in gewisser Weise ihr Werk selbst her. Das Bauen ist hier im Unterschied zum Pflegen ein Errichten. Beide Weisen des Bauens - bauen als pflegen, lateinisch colere, cultura, und bauen als errichten von Bauten, aedificare - sind in das eigentliche Bauen, das Wohnen, einbehalten". GA 7 [141], p. 149. See Basic writings, p. 349.

${ }^{459}$ My translation. Original: "gründet und vollendet den Bau der Kirche”. GA 13, p. 121.

460 Art and space, p. 307. Original: "Profane Räume sind stets die Privation oft weit zurückliegender sakraler Räume". GA 13, p. 207.

461 "Building Dwelling Thinking", p. 146. Original: "schweigt nur. Der Mensch freilich unterläßt es, auf dieses Schweigen zu achten". GA 7 [142], p. 150. See Basic writings, p. 350.
} 
dwelling. As Heidegger says: "Clearing-away is freeing of the places at which a god appears, the places from which the gods have fled, places at which the appearance of the divine hesitate for a long time. Clearing-away brings forth each place that prepares a dwelling" 462 .

Heidegger freely translates Heraclitus fragment 119, èthos anthrópo daimon, as "The (familiar) abode for humans is the open region for the presencing of god (the unfamiliar one) ${ }^{\prime 463}$. Humans authentically dwell when they step back before this unapparent dimension, making room for it. The difference between the location (Stelle), as an inauthentic place, and the site (Ort), as an authentic place, could be traced in the difference between what Heraclitus call, in fragment 78, "the human dwelling place" and "the divine dwelling place". According to Heraclitus ${ }^{464}$, the distinction lies in the fact that the human dwelling place doesn't have gnóme and the divine dwelling place does.

Heidegger's interpretation of this fragment understands gnóme as an originary counsel. "Gnóme originally means the kind of sensibility, and indeed the way in which every being lets itself be found and become visible" 465 . It could also mean "that kind of spirit $[M u t]$ according to which one is filled with courage [zumute]"466, which also inspires the meanings of "decision (...) and counsel"467. Mary could be related to this aspect as she is also called the Mother of good counsel. Athena too is said to be the resourceful counsellor, the one who, because sees the ownmost of things, premeditates. The Gospel of Luke also indicates an intimacy between a seeing and a premeditation:

'When you see a cloud looming up in the west you say at once that rain is coming, and so it does. And when the wind is from the south you say it will be hot, and it is. Hypocrites! You know how to interpret the face [prosopon] of the earth and the sky. How is it you do not know how to interpret these times? [kairon] ${ }^{368}$

\footnotetext{
${ }^{462}$ Art and space, p. 307. Original: "Räumen ist Freigabe der Orte, an denen ein Gott erscheint, der Orte, aus denen die Götter entflohen sind, Orte, an denen das Erscheinen des Göttlichen lange zögert. Räumen erbringt die jeweils ein Wohnen bereitende Ortschaft”. GA 13, p. 206-207.

463 "Letter on 'humanism" ", p. 271. Original: " $>>$ Der (geheure) Aufenthalt ist dem Menschen das Offene für die Anwesung des Gottes (des Un-geheuren) <<".

${ }^{464}$ Heidegger's translation of Heraclitus fragment: " $>>$ Der Aufenthalt, nämlich der menschliche (inmitten des Seienden im Ganzen), hat zwar nicht $\gamma \nu \omega \mu \alpha$, der Göttliche aber hat sie $<$. [ $v \theta \circ \zeta \gamma \alpha \rho \alpha v \theta \rho \omega \pi \varepsilon 10 v \mu \varepsilon v$ ouK $\varepsilon \chi \varepsilon 1 \gamma \nu \omega \mu \alpha \zeta, \theta \varepsilon 10 v \delta \varepsilon \varepsilon \chi \varepsilon 1]$ ]". GA 55, p. 350.

${ }^{465}$ My translation. Original: "Gnóme heißt eigentlich die Sinnesart, und zwar als die Weise, die alles Seiende begegnen läßt und erblickbar werden läßt”. GA 55, p. 350.

${ }^{466}$ My translation. Original: "jede Art von Mut (...), nach der einem zumute ist”. GA 55, p. 350.

${ }^{467}$ My translation. Original: "Entschluß (...) und Rat". GA 55, p. 350.

${ }^{468}$ Luke 12, 54-56.
} 
How is it you do not see the unapparent already being carried out in appearing ${ }^{469}$ ? How is it?

As a setting Being into work in a being, art is techne as a form of knowing. It "views ahead toward that which reveals the form and gives the measure, but which still remains invisible until is brought into the visibility and the perceptibility of the work" ${ }^{\prime 40}$. It has previously been said in this chapter that the divine abode is "the presencing of an insight" ${ }^{471}$, which, I add, glances toward the unapparent incessant rise. Because such unapparent rise traverses everything, it directs and illuminates. Because it guides everything, it also unifies all and can only be appropriated by itself. That's why to put to work, human being must make room to this gathering. It is only such oneness of the incessant rise what can guide the authentic setting into work.

The divine dwelling place is set up in the unapparent. In the previous chapter, it was said that 'setting' means "placing as allowing to arise",472. According to Heidegger, the Greek 'setting' also means "laying, laying down a sacred offering. 'Placing' and 'laying' have the sense of bringing hither [her] [here] into unconcealment, bringing forth among what is present, that is, allowing to lie forth [vor] [my highlights]"473. To build as dwelling is such setting up, which

is erecting in the sense of dedication and praise. Here 'setting up' no longer means a bare placing. To dedicate means to consecrate, in the sense that in setting up the work the holy is opened up as holy and the god is invoked into the openness of his presence. Praise belongs to dedication as doing honor to the dignity and splendor of the god. Dignity and splendor are not properties beside and behind which the god, too, stands as something distinct, but it is rather in the dignity, in the splendor that

\footnotetext{
${ }^{469}$ The quote from the Gospel is usually understood as referring to Jesus Christ as the sign to be interpret in the sense that the messianic times had already arrived. I am suggesting an interpretation in the light of Heidegger's remarks. In this sense, it is worth mentioning a verse by Hölderlin, from Vista (Die Aussicht), which Heidegger quotes: "Nature supplies the image of times (die Natur ergänzt das Bild der Zeiten)". Apud GA 7 [198], p. 208. My translation.

470 "The provenance of art and the destination of thought", p. 120. Original: "vorblickt in das Gestalt-weisende, Maßgebende, aber noch Unsichtbare, das erst in die Sichtbarkeit und Vernehmbarkeit des Werkes gebracht werden soll”. GA 80. In: http://www.eudia.org/wp /download.php?id=1142, p. 3-4.

${ }^{471}$ My translation. Original: "die Gegenwart der Hereinblickenden". GA 55, p. 351.

${ }^{472}$ OWA, in Off Beaten, p. 53. Original: "Stellen als Erstehenlassen". GA 5 [68], p. 70.

${ }^{473}$ OWA, in Off Beaten, p. 53. Original: "Legen, Niederlegen eines Weihegeschenkes. Stellen und Legen haben den Sinn von: Her- ins Unverborgene, vor- in das Anwesende bringen, d. $h$. vorliegenlassen". GA 5 [68], p. 70.
} 
the god is present. In the reflected glory of this splendor there glows, i.e., there lightens itself, what we called the word. To e-rect means: to open the right in the sense of a guiding measure, a form in which what belongs to the nature of being gives guidance [my highlights] $]^{474}$.

The work of art is itself a setting up as a bringing Being forth into unconcealment. That's why the work is said to be a temple of truth. To consecrate as to make sacred is to make the holy appears in its openness, that is, to make the ownmost of things appear in splendor, a guiding splendor. As Heraclitus says, "the thunderbolt steers all" 475 . Heidegger asks himself what does "to steer" (steuern) means and suggests that: "The steering gathers all in advance in a path and, so gathering, it shows the way, keeping it gathered to the open ahead" 476 . He adds that, "From the outset, presences in the steering the present within which that which comes to an encounter in a steering way may conceal and unconceal itself' ${ }^{477}$.

The authenticity of this setting up is granted through the consecration as the memory of the sacred, that is, of the oneness that unifies all. The enowning (Ereignis) as an appropriation of the unapparent is such remembrance. In the text On the Sistine Madonna, Heidegger indicates that such appropriation of itself ${ }^{478}$ happens at the altar, which is known to be the site of the memory of the sacred. The disclosure of appropriation (Ereignis) sanctifies as the altar makes sacred.

In Why poets?, Heidegger says that "Memory [Er-innerung], making inward, inverts [wendet] our essence that only wills assertively, and its objects, into the innermost [innerste] invisibility of the heart's space [my highlights]"479.

474 OWA, in PLT, p. 42-43. Original: "ist das Errichten im Sinne von Weihen und Rühmen. Aufstellung meint hier nicht mehr das bloße Anbringen. Weihen heißt heiligen in dem Sinne, daß in der werkhaften Erstellung das Heilige als Heiliges eröffnet und der Gott in das Offene seiner Anwesenheit hereingerufen wird. Zum Weihen gehört das Rühmen als die Würdigung der Würde und des Glanzes des Gottes. Würde und Glanz sind nicht Eigenschaften, neben und hinter denen außerdem noch der Gott steht, sondern in der Würde, im Glanz west der Gott an. Im Abglanz dieses Glanzes glänzt, d. h. lichtet sich jenes, was wir die Welt nannten. Er-richten sagt: Öffnen das Rechte im Sinne des entlang weisenden Maßes, als welches das Wesenhafte die Weisungen gibt". GA 5 [33], p. 30.

${ }^{475}$ Heraclitus' fragment 64: “ $\tau \alpha \delta \varepsilon \pi \alpha \nu \tau \alpha$ ol $\alpha \kappa \imath \xi \varepsilon 1 \kappa \varepsilon \rho \alpha u v o \zeta$ ”. See KIRK, G.; RAVEN, J.. The presocratic philosophers, p. 199. An alternative translation would be: "The lightning rules all".

${ }^{476}$ My translation. Original: "Das Steuern versammelt im vorhinein alles in eine Bahn, und also versammelnd weist es den Weg, hält ihn gesammelt zum voraus offen”. GA 55, p. 351.

${ }^{477}$ My translation. Original: "Im Steuern west im vorhinein die Gegenwart, innerhalb deren das auf der gesteuerten Bahn Begegnende an- und abwesen kann”. GA 55, p. 351.

478 That is: as the becoming man of God, as this transformation "that enowns itself at the altar as transubstantiation". GA 13, p. 121.

479 "Why poets?", p. 231. Original: "Die Er-innerung wendet unser nur durchsetzend wollendes Wesen und seine Gegenstände in das innerste Unsichtbare des Herzraumes um". GA 5 [285], p. 309. 
The heart is related to memory as to what is known by heart. Turned toward our hearts, we free ourselves. "For what is remembered (made inward) as well as where it is remembered (made inward) are of such an essence. Memory, making inward, reverses [Umkehrung] departure into the arrival into the widest compass of the open [my highlights]" 480 . Again: memory transforms [wendet] our essence. Remembering, it takes place a transformation from inauthenticity to authenticity. As a making inward, memory recalls the unapparent openness as a disclosure of appropriation (Ereignis). To know by heart is to know by the ownmost of things.

As said in the previous chapter, thinking (denken) as thinking of [andenken] Being is remembrance (Andenken) of Being. According to Heidegger,

Thinking is indeed a serious matter, but at the same time a festive one. For in thinking, the insight into that which is is freed, i.e., given a free day for celebration. Meditation is not melancholy but gladsomeness in which everything is gladdened, everything becomes clear and transparent ${ }^{481}$.

In Messkirch' Seventh centennial, after his remarks on the search in the cemetery for the remembrance of home ${ }^{482}$, Heidegger refers to the exhibition organized by the occasion of the celebration of his city seventh centennial. He says that the exhibition

is a real 'occasion' $\left[\right.$ Anlaß], that is, the feast $\left[{ }^{483}\right]$ in the authentic sense. For these works occasion [veranlaßt] us not only to rejoice in the beauty of the pictures, not only to wonder at the artistic accomplishment of the Master. The exhibit is the occasion for us to find our way back, in the presence of these works, into rest and in-gathering [die Ruhe und Sammlung], i.e., into Home [Heimische] ${ }^{484}$.

\footnotetext{
480 "Why poets?", p. 232. Original: "Denn sowohl das, was er-innert wird, als auch das, wohin es er-innert wird, ist solchen Wesens. Die Erinnerung ist die Umkehrung des Abschiedes zur Einkehr in den weitesten Umkreis des Offenen". GA 5 [285], p. 309.

481 "Messkirch's seventh centennial", p. 55. Original: "Das Denken ist zwar eine ernste Sache, aber zugleich eine festliche. Denn im Denken wird die Einsicht in das, was ist, freigegeben, d. h. gefeiert. Besinnung ist nich t Trübsinn, sondern die Heiterkeit, in der sich alles aufheitert, hell wird und durchsichtig". GA 16, p. 582.

${ }^{482}$ It has already been discussed in the previous chapter.

${ }^{483}$ See OWA [8]: "das Fest des Denkens", "the feast of thought".

${ }^{484}$ Messkirch's seventh centennial", p. 53. Original: "ist ein echter $>>A n l a ß<<$, d. h. das Fest im eigentlichen Sinne. Denn dieses Werk veranlaßt uns, nicht nur an der Schönheit der Bilder uns zu erfreuen, nicht nur die künstlerische Leistung des Meisters zu bewundern. Die Ausstellung ist der Anlaß, vor diesem Werk in die Ruhe und Sammlung, d . h . in das Heimische zurückzufinden". GA 16, 581.
} 
As the graveyard ${ }^{485}$, the feast is the occasion for a transformation as a way back home.

Still in Messkirch' Seventh centennial, Heidegger says that, despite the times of forgottenness we live in, "there still is homeland, and it affects us - but as that for which we are searching" 486 . This means that "The homeland does not exist on this Earth [my highlights]"487, as he stresses in Language and homeland (Sprache und Heimat). It is destiny (Schicksal). It is "each time this (jeweilen diese)" 488 , what is a characterization close to the one Heidegger provides, in the text On the Sistine Madonna, to what he meant by "this church" as the church to which the Sistine belongs. "This church" means, let's remember: "each one", "each one, singular as this one". As what singularizes the Sistine is enowning (Ereignis), as I argue, what singularizes "destiny (Geschick) $\left[{ }^{489}\right]$ [is that it] propriates [ereignet sich] as the clearing of being - which it is ${ }^{\$ 490}$. It is worth noticing that, when Heidegger says that in the Sistine "it happens [geschieht] the appearing of the becoming man of God"491, it is this correlate word that is employed: geschieht ${ }^{492}$. According to Heidegger, "Destiny (Geschick) (...) is essentially the dispensation (Geschick) of being, so much so that being itself sends (schick) itself and each time essences as a dispensation (Geschick) and destinally

\footnotetext{
${ }^{485}$ In Le dépouillement: expositions de la mère, Hamacher mentions that one of the metaphors associated to the museum is to call it a graveyard (un cimetière). He says that: "the museum is a mausoleum, a memorial, a cemetery". Original: "Le musée est un mausolée, un mémorial, un cimetière", p. 95 .

${ }^{486}$ Messkirch's seventh centennial", p. 51. Original: "Sie ist noch und geht uns an, aber als die gesuchte". GA 16, p. 579.

${ }^{487}$ My translation. "Language and homeland". Original: "D i e Heimat gibt es nicht auf dieser Erde". GA 13, p. 156.

${ }^{488}$ My translation. GA 13, p. 156.

${ }^{489}$ According to Inwood the distinction between Schicksal and Geschick does not survive Being and Time. After that, both terms are "often interchangeable". Cf. A Heidegger dictionary, p. 68.

490 "Letter on 'humanism"”, p. 257. Original: "Geschick ereignet sich als die Lichtung des Seins, als welche es ist". GA 9 [168], p. 337.

${ }^{491}$ My translation. GA 13, p. 121.

${ }^{492} \mathrm{It}$ is also worth mentioning its employment in three other important passages of the text $O n$ the Sistine Madonna: 1) when he states that "To the singular event [Geschehnis] of the image corresponds its singularizing in the unapparent site [Ort]" (see page 91 of this dissertation); 2) when Heidegger uses the expression "the unique event (Geschehnis) of this unique image" and 3) when he says that "The bringing in which Mary and the Infant Jesus have their essence gathers its happening (Geschehen) in the glancing look". Original: "Dem einzigen Geschehnis des Bildes entspricht notwendig seine Vereinzelung an den unscheinebaren Ort"; "dem einzigen Geschehnis dieses einzigen Bildes"; "Das Bringen worin Maria und der Jesusknabe wesen, versammelt sein Geschehen in das blickende Schauen". GA 13, p. 121.
} 
transforms [wandelt $]$ itself in accordance with this" ${ }^{" 493}$. The homeland (Heimat) is "that which sustains and determines and lets us grow in the core of our existence" ${ }^{" 494}$. It is nearness to the ownmost of things, "nearness to being"495.

As the glance toward being happens in a lightning flash, in a sudden unapparent appearing, it happens in an instant. In times of forgottenness, the homesickness encounters man, for example, in the boredom of a long instant (Langeweile). In it, the strangeness of the ordinary reaches man and he seeks for that which addresses him. Michell clarifies that "The thing abides (weilt). It remains for a while (eine Weile). This 'while' is the duration (die Weile) of that which abides (ein Weiliges). (...) There is a calm to it (a Ruhe and a Stille), but it is a calm that is coterminous with the shortness of one's stay"496. The silence (Ruhe), as the nameless, is coterminous with the suddenness of a seeing in which we briefly dwell.

The strangeness might also arrive as "the muffled tolling of a bell that resounds into Dasein and gradually fades away"497. In Introduction to metaphysics, Heidegger describes: "in heartfelt joy (...) all things are transformed [verwandelt] and surround us as if for the first time, as if it were easier to grasp that they were not, rather than that they are, and are as they are [my highlights]" ${ }^{" 498}$. The transformation that happens in such an instant refers to a grasp in which things appear as if "they were not". We could say that they appear bringing to evidence its unapparent character as incessant rise. Since what shines is the unapparent, it might seem as if things were not. Such insight

arouses the suspicion that truth, as the unconcealedness of Being, is not necessarily dependent on embodiment.

\footnotetext{
${ }^{493}$ Bremen and Freibug lectures, p. 65. Original: "Geschick (...) ist wesenhaft Geschick des Seins, so zwar, daß das Sein selber sich schickt und je als ein Geschick west und demgemäß sich geschicklich wandelt". GA 79, p. 69.

${ }^{494}$ Messkirch's seventh centennial", p. 51. Original: "solches, was uns im Kern unseres Daseins trägt und bestimmt und gedeihen läßt". GA 16, p. 580.

${ }^{495}$ Original: "die Nähe zum Sein". GA 9 [169], p. 338.

${ }^{496}$ MITCHELL, A. "Translator's foreword". In: Bremen lectures, p. x.

${ }^{497}$ IM, p. 2. Original: "ein dumpfer Glockenschlag, der in das Dasein hereintönt und mählich wieder verklingt". GA 40 [1], p. 3.

${ }^{498}$ IM, p. 2. Original: "In einem Jubel des Herzens (...) alle Dinge verwandelt und wie erstmalig um uns sind, gleich als könnten wir eher fassen, daß sie nicht sind, als daß sie sind und so sind, wie sie sind". GA 40 [1], p. 3.
} 
Goethe says: 'It is not always necessary that what is true should embody itself; it suffices for it to float about intelligibly and evoke harmony as it drifts through the air like a serious but friendly sound of a bel' [my highlights] ${ }^{499}$.

The incessant rise is related to the seeing of the appearing of things as a whole. It refers to the unapparent harmony that, although apparent in appearing, also withdraws. The unapparent as this withdrawal aspect floats about the coming forth of things.

Again: thinking is "a serious matter, but at the same time a festive $\left[{ }^{500}\right]$ one[, a "heartfelt joy"]. For in thinking, the insight into that which is is freed [my highlights]" 501 . The "heartfelt joy" instant brings forth the memory of the incessant rise. Such instant becomes an altar, the site of such remembrance, once it celebrates the oneness. As Heidegger says, "Being traverses, as itself, its precinct [Bezirk] which is demarcated [bezirkt] ( $\tau \varepsilon \mu v \varepsilon \mathrm{v} v$, tempus) by the fact that it essences in the word. Language [ $\left.{ }^{502}\right]$ is the precinct [Bezirk] (templum), i.e., the house of being"503. In A Dialogue on Language, a Japanese and an inquirer, Heidegger himself, discuss the translation of 'language' to Japanese. They say:

I[nquirer]: What is the Japanese word for "language"?

J[apanese]: (after further hesitation) It is "Koto ba".

I: And what does that say?

\footnotetext{
${ }^{499}$ Art and Space, p. 309. Original: "läßt vermuten, daß die Wahrheit als die Unverborgenheit des Seins nicht notwendig auf Verkörperung angewiesen ist. / Goethe sagt: >> Es ist nicht immer nötig, daß das Wahre such verkörpere; schon genug, wenn es geistig umherschwebt und Übereinstimmung bewirkt, wenn es wie Glockenton Ernst-freundlich durch die Lüfte wogt. $<<"$. GA 13, p. 210.

500 'Festive' [festliche] is related to the German 'Fest', which means fixed, brought into the outline. The feast might be then related to the bringing into emergence. According to Heidegger, "The boundary which fixes and consolidates is what reposes, reposes in the fullness of movement". The advent of truth must be thought as " 'fixing in place' in the sense (...) [of] the key specification 'setting-to-work'”. In: OWA, in OBT, p. 52-53. GA 5 [68], p. 70-71. Original: "Die festigende Grenze ist das Ruhende - nämlich in der Fülle der Bewegtheit"; "Feststellen in dem Sinne (...) der Leitbestimmung >> Ins-Werk-Setzen <<". See note 257. See also OWA, in PLT, p. 82 . GA 5 [68], p. 71.

501 "Messkirch's seventh centennial", p. 55. Original: "eine ernste Sache, aber zugleich eine festliche. Denn im Denken wird die Einsicht in das, was ist, freigegeben". GA 16, p. 582.

${ }^{502}$ Because logos, as physis, is a gathering, they are both the same. See IM [100]. GA 40.

503 "Why poets?", p. 232. Original: "Das Sein durchmißt als es selbst seinen Bezirk, der dadurch bezirkt wird ( $\tau \varepsilon \mu \nu \varepsilon i v$, tempus), daß es im Wort west. Die Sprache ist der Bezirk (templum), d. h. das Haus des Seins". GA 5 [286], p. 310.
} 
$\mathrm{J}: b a$ means leaves, including and especially the leaves of a blossom-petals. Think of cherry blossoms or plum blossoms.

I: And what does Koto say?

$\mathrm{J}$ : This is the question most difficult to answer. But it is easier now to attempt an answer because we have ventured to explain Iki: the pure delight of the beckoning stillness. The breath of stillness that makes this beckoning delight come into its own is the reign under which that delight is made to come. But Koto always also names that which in the event gives delight, itself, that which uniquely in each unrepeatable moment comes to radiance in the fullness of its grace.

I: Koto, then, would be the appropriating occurrence [Ereignis] of the lightening message of grace [my highlights] $]^{504}$.

Language, in this sense, is the blooming of the message of grace in enowning (Ereignis), which, in a moment, in an unrepeatable moment, arrives in an unique way. As coming into its own, it is also "the reign", the site, the unapparent site. It is the message of a transformation that brings forth a brilliant shine.

Heidegger states that "all creatures, each in its own way, are (as beings) in the precinct of language. That is why only in this precinct, if anywhere, can the reversal from the region of objects and their representation into the innermost of

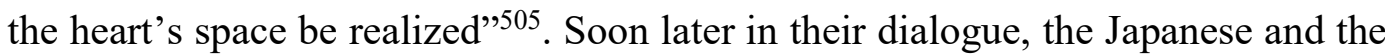
inquirer say:

J: (...) It seems to me more helpful to turn to the Greek word charis, which I found in the lovely saying that you quote from Sophocles, in your lecture '... Poetically Man Dwells ...', and translated 'graciousness.' This saying comes closer to putting into words the breathlike advent of the stillness of delight.

\footnotetext{
504 “A dialogue on language", p. 45. Original: "F[:] Wie heißt das japanische Wort für »Sprache«? / J[:] (nach weiterem Zögern) Es heißt $>>$ Koto $b a<<. /$ F[:] Und was sagt dies? / J[:] ba nennt die Blätter, auch und zumal die Blütenblätter. Denken Sie an die Kirschblüte und an die Pflaumenblüte. / F[:] Und was sagt Koto? / J[:] Diese Frage ist am schwersten zu beantworten. Indessen wird ein Versuch dadurch erleichtert, daß wir das $I k i$ zu erläutern wagten: das reine Entzücken der rufenden Stille. Das Wehen der Stille, die das rufende Entzücken ereignet, ist das Waltende, das jenes Entzücken kommen läßt. Koto nennt aber immer zugleich das jeweils Entzückende selbst, das einzig je im unwiederholbaren Augenblick mit der Fülle seines Anmutens zum Scheinen kommt. / F[:] Koto wäre dann das Ereignis der lichtenden Botschaft der Anmut". GA 12 [142], p. 134-135.

505 "Why poets?", p. 233. Original: "alle Wesen sind je nach ihrer Weise als seiende im Bezirk der Spracbe. Darum ist, wenn irgendwo, allein in diesem Bezirk die Umkehr aus dem Bereich der Gegenstände und ihres Vorstellens in das Innerste des Herzraumes vollziehbar". GA 5 [286], p. $310-311$.
} 
I: And something else, too, that I wanted to say there but could not offer within the context of the lecture. charis is there called tiktousa - that which brings forward and forth. Our German word dichten, tihton says the same. Thus Sophocles' lines portend to us that graciousness is itself poetical, is itself what really makes poetry, the welling-up of the message of the two-fold's unconcealment [my highlights] ${ }^{506}$.

Thus, poetic language brings forth grace as a transformation in appearing from opacity to brilliance, as the message of the mutual belonging of concealment and unconcealment. In Language and homeland (Sprache und Heimat), Heidegger quotes a poem by Hebel, Summer twilight (Sommerabend), which says in one verse: "It is a thing, I do say ${ }^{507}$ / In the morning grass and in the evening hay" 508 . From grass to hay might mean from opacity to brilliance. The grass is green, the hay is like gold. In the evening ${ }^{509}$, in its withdrawal, a thing shines in brilliance.

Charis, says the inquirer, is that which brings forth. It is the advent that brings forth grace. Transubstantiation is the celebration of Eucharistic, which is a celebration of thanks and praise. As thanksgiving, it is a celebration addressing the memory of the sacred. At the altar, the making sacred is a making shine in brilliance as remembrance. According to Heidegger,

In sacrifice [Opfer] there occurs [ereignet sich] the concealed thanks that alone pays homage to the grace that being has bestowed upon the human essence in thinking, so that human beings may, in their relation to being, assume the guardianship of being. Originary thinking [Das anfängliche Denken] is the echo of

\footnotetext{
506 "A dialogue on language", p. 46. Original: " J[:] denen die Expression zugeordnet bleibt als die Art der Befreiung. Hilfreicher scheint mir die Zuwendung zum griechischen Wort $\chi \alpha \rho l \zeta$, das ich in dem schönen Spruch fand, den Sie in Ihrem Vortrag $>>$... dichterisch wohnet der Mensch ... << aus Sophokles anführten, und das Sie mit $>>$ Huld $<<$ übersetzten. Darin spricht eher das wehende Ankommen der Stille des Entzückens. / F[:] Zugleich noch anderes, was dort gesagt sein möchte, aber im Rahmen des Vortrages nicht dargetan werden konnte. Die $\chi \alpha \rho \imath \zeta$ heißt dort $\tau \imath \chi \tau o v \sigma \alpha-$ die her-vor-bringende. Unser deutsches Wort dichten, tihton, sagt das Selbe. So kündigt sich im Spruch des Sophokles für uns an, daß die Huld selbst dichterisch, das eigentlich Dichtende ist, das Quellen der Botschaft des Entbergens der Zwiefalt". GA 12 [143], p. 135.

${ }^{507}$ In Old German, it says "bi miner Treu", which means "bei meiner Treu". 'Treu' is faith. The meaning as "I do say" seems to be close to "I give faith". The translator choice maintained the rhyme. We might wonder if it could be traced a relation between the use of this word and the transformation from opacity to brilliance that is being discussed in this dissertation. In this context, it is relevant to add that transubstantiation is known to be a mystery of faith. It is also worth noticing that the poem addresses the work of the sun.

${ }^{508}$ Translation by Capobianco, R. In: Heidegger on Hebel: the inexhaustible depth of things, p. 2. Original: "Es isch e Sach, bi miner Treu, / am Morgen Gras und z'obe Heu!". GA 13, p.161.

${ }^{509} \mathrm{Or}$ in the twilight of appearing and withdrawal. It is interesting recalling too the owl's eye that sees at night.
} 
being's favor, of a favor in which a singular event [das Einzige] is cleared and lets come to pass [sich ereignen]: that beings are [my highlights $]^{510}$.

The sacrifice ${ }^{511}$ of the Mass (Meßopfers) is the offer of the Mass (Me $\beta$-opfers). What is offered at Mass is man's heart ${ }^{512}$. By emptying himself, he may echo grace. Heidegger says that "Sacrifice is at home in the essence of the event [Ereignis] whereby being lays claim upon the human being for the truth of being" $" 513$. It requires a renunciation as a transformation that enables such echoing. The way of an "originary thanking" as a preserving of the truth of being is the way of "the nobility $\left[{ }^{514}\right]$ of a poverty in which the freedom [Freiheit] of sacrifice conceals the treasure of its essence" $" 515$. Freedom, as also already discussed in the previous chapter, means to be released to the ownmost of things.

As discussed in the previous chapter, Mary is the poor one. Her poverty granted her the bearing of life, her motherhood character. Such bearing interpreted as the openness to the ownmost of things is the building of a temple. The openness of the face-to-face of Rodin's carved hands also builds a temple, which was once called Ark of the covenant, one of Mary's titles. The poet too builds, once he opens himself to the singing of the poetic song.

Where does he [the poet] go? To renunciation, which he has learned. This learning was a sudden [Augenblick] experience which he had in that instant when the wholly different rule of the word looked at him and disturbed the self-assurance of

\footnotetext{
510 "Postscript to 'What is Metaphysics?'”, p. 236. Original: "Im Opfer ereignet sich der verborgene Dank, der einzig die Huld würdigt, als welche das Sein sich dem Wesen des Menschen im Denken übereignet hat, damit dieser in dem Bezug zum Sein die Wächterschaft des Seins übernehme. Das anfängliche Den-ken4 ist der Widerhall der Gunst des Seins, in der sich das Einzige lichtet und sich ereignen läßt: daß Seiendes ist". GA 9 [105], p. 310.

${ }^{511}$ For more on sacrifice and Heidegger, see REIS, R. "Verdade e sacrifício na intencionalidade social".

${ }^{512}$ See VERNANT, J. "At man's table". In this article, Vernant elucidates that, in Greek sacrifice, it was not the bad parts, but the very life of the animal that was offered to the gods as what belonged to them. Through the sacrificial fire, the life of the animal was "released from the bones with the soul at the moment the victim falls dead and (...) [in which it] escape[s] the putrefaction of death" (p. 25), rising as smoke to the sky. According to Vernant, man eats the flesh, the dead flesh of the animal as a remembrance of the distance between him and the gods. The sacrifice was a kind of bridge between them as such remembrance of human's origin and its distance to the gods.

513 "Postscript to 'What is Metaphysics?'”, p. 237. Original: "Das Opfer ist heimisch im Wesen des Ereignisses, als welches das Sein den Menschen für die Wahrheit des Seins in den Anspruch nimmt". GA 9 [106], p. 320.

${ }^{514}$ For more on what is 'noble', see GA 55, p. 144.

515 "Postscript to 'What is Metaphysics?'”, p. 236. Original: "den Adel der Armut (...), in der die Freiheit des Opfers den Schatz ihres Wesens verbirgt”. GA 9 [106], p. 311.
} 
his earlier Saying. Something undreamed of, something terrifying stared him in the face - that only the word lets a thing be as thing ${ }^{516}$.

At that instant in which the nature of poetry and the nature of dwelling appear as belonging together, "the 'undreamed terror' does not destroy him. But it does bend him to the ground as the storm bends the tree, so that he may become open"517. Such openness as the echo of the ownmost of things builds a temple. According to Heidegger, "Saying [is]: a quiet, exuberant bow, a jubilant homage, a eulogy, a praise: laudare. Laudes is the Latin name for songs. To recite song is: to sing. Singing is the gathering of Saying in song"518. In Bremen and Freiburg lectures, Heidegger quotes Johann Georg Hamann: "Poetry is the mother-tongue of the human race" ${ }^{\$ 19}$. As an authentic saying, it bears life. It bears the breath of the ownmost of things.

Such echoing is a bowing also as an obedience ${ }^{520}$ to what is heard. To obey is to echo that things are, which is the song that "sleeps in all things". Authentic hearkening (Hörigsein) "means obediently following what logos is: the gatheredness of beings themselves"521. It means to belong (gehören) to the ownmost of things as the incessant rise of physis, which is also a gathering as the one inherent to logos. It means to belong (gehören) as echoing the mutual belonging of concealment and unconcealment. It also means then to belong as enowning (Ereignis), that is, as letting the ownmost of things mirrors itself through human being.

\footnotetext{
516 “Words", p. 148. Original: "Wohin? In den Verzicht, den er lernte. Dieses Lernen war eine jähe Erfahrung in dem Augenblick, da ihn das ganz andere Walten des Wortes anblickte und die Selbstsicherheit seines vormaligen Sagens erschütterte. Unerahntes, Schreckhaftes blickte ihn an, dies, daß erst das Wort ein Ding als Ding sein läßt”. GA 12 [229], p. 216.

517 "Words", p. 149. Original: "der $>>$ unerahnte Schreck $<<$ zerstört ihn nicht. Doch er beugt ihn zu Boden wie der Sturm den Stamm, damit er offen werde". GA 12 [231], p. 218.

518 "Words", p. 149. Original: "das Sagen: ein still frohlockendes Sichbeugen, ein jubelndes Verehren, ein Preisen, ein Loben: laudare. Laudes lautet der lateinische Name für die Lieder. Lieder sagen heißt: singen. Der Gesang ist die Versammlung des Sagens in das Lied". GA 12 [229], p. 216.

519 Apud "Bremen and Freiburg lectures", p. 162. Original: "Poesie ist die Muttersprache des menschlichen Geschlechts". GA 79, p. 172. See also "Sprache und Heimat", p. 156. "Language is language as mother-tongue (Sprache ist Sprache als Muttersprache)".

${ }^{520}$ For an analysis of Rugen's notion of "landscape of the soul", see chapter 5 of PUTSCHER, M. Raphaels Sixtinische Madonna. In this text, there is also a commentary that suggests that Goethe's fifth act of the second part of the Faust is a translation (this term is also used as a concept by Rugen. - It is not possible to describe, just to translate. -) of the Sistine Madonna. It is worth noticing that Goethe's Faust is known to address the renunciation of a will that wants unlimited knowledge.

${ }^{521}$ IM, p. 137. Original: "besagt: Folge leisten ge-genüber dem, was der $\lambda$ ó ${ }^{\circ} \varsigma$ ist: die Gesammeltheit des Seien-den selbst". GA 40 [99], p. 138.
} 
Again: to hold this ownmost is to build a temple. As Ark of the covenant, the temple also refers to a womb, a place where a new inception rises. The temple is the site of a transformation as a new birth understood as a new way of seeing tuned by the unapparent mutual belonging of concealment and unconcealment ${ }^{522}$. As Heidegger says "The evening [Abend] is the time and hour for meditation" that is, for such unapparent shine in brilliance. That is why the temple is also a tomb as a place that gives the occasion for a transformation from death to a new life, that is, from inauthenticity to authenticity. In its being, a thing, even in its inauthenticity, carries out a mystery. That is why once a toilette could become a Fountain, the source of a new inception. It could become art because it already carried this possibility as being a thing, a mystery. It could become art not as an object, but as provoking a transformation of seeing toward the unapparent of its belonging to the incessant rise of physis ${ }^{524}$. Thus, a dead thing holds the occasion for a new rise.

For the ancient Egyptians, who "have made of death their passion" 525 , the dead is the one "who is at the frontier" 526 between life and death. Might we translate this, in the light of Heidegger remarks, as: the dead is the one who is at the in-between, and thus sees the unapparent mutual belonging of concealment and unconcealment? According to Bailly, to Egyptian civilization:

The dead is indeed the mystic, and the perfect mystic, the one who sees the god and that, having seen, will never say anything. To see the god was, we know, for the Greeks, impossible and numerous are the myths which evoke the transgression of this interdict and the condemnation that follows it. Only the mysteries give furtive access, mysteriously, to this vision. For the Egyptians, the images of the gods were

\footnotetext{
522 The Virgin Mary as a Madonna of Victory might be related to this new birth as to the victory of a transformation as a new rise.

523 "Messkirch's Seventh centennial", p. 41. Original: "der Abend ist Zeit und Stunde der Besinnung". GA 16, p. 574

${ }^{524}$ It is interesting to notice, in this context, the singularity of the Sistine Madonna as art, because it seems as if it were kind of "evidently aware" (as transparently on its ownmost?) of this mysterious appearing of the mutual belonging of concealment and unconcealment. The image forming a window faces the mutual bringing of the Mother and her Son. The image seems to somehow highlight this issue, as being a transparent happening of the possibility of an authentic disclosure of appropriation (Ereignis). See GA 7 [107], p. 207, for the distinction between authenticity and inauthenticity in relation to the poetic. "Poetry is authentic or inauthentic according to the degree of this appropriation [Vereignung]". "...Poetically Man Dwells...", p. 226. Original: "Je nach dem Maß dieser Vereignung ist das Dichten eigentlich oder uneigentlich".

${ }^{525}$ My translation. BAILLY, J. L'apostrophe muette: essai sur les portraits du Fayoum, p. 72. Original: "[une civilization qui] avait fait d'elle [la mort] sa passion".

${ }^{526}$ My translation. BAILLY, J. L'apostrophe muette: essai sur les portraits du Fayoum, p. 66. Original: "qui est à la frontière".
} 
not their true form and only the deads could know this form and access it (...) by becoming themselves divines ${ }^{527}$.

In this context, to become divine by dying means becoming divine by being rendered to "the very power of existence" ${ }^{528}$. I translate again: by authentically belonging to being as obeying it, bowing to it?

Another interesting aspect concerning this civilization is that, for Egyptians,

Only the tomb is the true home, the necropolis is $<<$ the site where the gods are $>>$, which the deads have joined. Hence the importance and the special status of funerary painting and representations, which are at once hotel and home and which, with images, unfold, but as default, the true form, invisible as such, of the gods. (...) In any case, we can see the link that could, at the time of portraits $\left[{ }^{529}\right]$, be established between the representation of the not representable that the Egyptian conception proposed and the incursion on the sudden visibility of the invisible which the cults of mystery were supposed to be the occasion ${ }^{530}$.

Thus, the funerary representation "is not a representation of death, it is that which we cannot see, it is that which waits for the dead"531: a transformation. This new birth that waits for the dead is dependent on the kind of relation he developed with $\operatorname{truth}^{532}$. The measuring of such relation is addressed in their funerary paintings

${ }^{527}$ My translation. BAILLY, J. L'apostrophe muette: essai sur les portraits du Fayoum, p. 66. Original: "Le mort en effet est le myste, et le myste parfait, celui qui voit le dieu et qui, ayant vu, ne dira jamais rien. Voir le dieu, c'était, on le sait, pour les Grecs, l'impossible, et nombreux sont les mythes évoquant la transgression de cet interdit et la condamnation qui s'ensuivait. Seuls les mystères donnaient accès furtivement, mystérieusement, à cette vision. Pour les Égyptiens, les images des dieux n'étaient pas leurs formes véritables, et seuls les morts pouvaient connaître cette forme et y accéder (...) en devenant eux-mêmes divins".

${ }^{528}$ My translation. BAILLY, J. L'apostrophe muette: essai sur les portraits du Fayoum, p. 73. Original: "la puissance même de l'existence".

${ }^{529}$ It is interesting keeping in mind here the discussion addressed at the end of the previous chapter on portraits.

${ }^{530}$ My translation. BAILLY, J. L'apostrophe muette: essai sur les portraits du Fayoum, p. 66. Original: "Seul le tombeau est la vraie maison, la nécropole est $<<$ le lieu où sont les dieux $>>$, que les morts ont rejoint. D'où l'importance et le statut particulier de la peinture et des representations funéraires, qui sont tout à la fois hôtel et maison et qui, avec des images, déplient, mais comme par défaut, la forme vraie, invisible comme telle, des dieux (...). L'on voit en tout cas le lien qui pouvait à l'époque des portraits s'établir entre la représentation de l'irreprésentable que la conception égyptienne proposait et cette incursion dans la visibilité soudaine de l'invisible dont les cultes à mystères étaient censés être l'occasion".

${ }^{531}$ My translation. BAILLY, J. L'apostrophe muette: essai sur les portraits du Fayoum, p. 66. Original: “n'est pas une $<<$ representation de la mort $>>$, c'est ce qu'on ne peut pas voir, c'est ce qui attend le mort".

532 They called it Maat, "a ruling principle of rightness, order, and justice believed by Egyptians to permeate the cosmos". RUSSMANN, E. Eternal Egypt, p. 265. 
and representations. It "was seen to be literally a 'moment of truth' [my highlight]" 533 .

The moment of judgement as a moment of measuring was seen as a moment of truth. A famous element of the Hall of judgement scene found in Egyptian papyrus and tombs is a scale in which lies, on one side, the heart of the one being judge and, on the other side, an ostrich feather ${ }^{534}$. It would be possible to say then that the heart is brought forth in a kind of face-to-face with a feather on the scale. The human being's heart ${ }^{535}$ is measured by means of a face-to-face with the ostrich feather, which is, for the Egyptians, the representation of truth. Man's heart is thus brought face-to-face with truth. For the Egyptians, such measuring addresses the life the person has lived ${ }^{536}$. The face-to-face with truth is related to the measuring of to what extent the person's life mirrored truth ${ }^{537}$. Ani, the Theban scribe whose moment of truth is depicted in the papyrus on next page, is considered justified and receives the epithet "true of voice" (Maat Kheru). To be justified is to be literally "true of voice". It means that his life truly expressed truth. Does it mean then that he "truly echoed" truth? Does it mean that he lived an authentic life?

\footnotetext{
${ }^{533}$ RUSSMANN, E. Eternal Egypt, p. 199.

534 See figure 5, on next page. Anubis, the jackal-headed god, checks the scale, where Ani's heart is placed. He was the god of "embalming, guardian of the cemetery and of the deceased". In: RUSSMANN, E. Eternal Egypt, p. 262. According to Bailly, despite seeming scary to us, Anubis was "pure hospitality (pure (...) accueil)". BAILLY, J. L'apostrophe muette: essai sur les portraits du Fayoum, p. 64.

${ }^{535}$ Ani, a king's scribe, is, in this case, the one who is being judge in the figure on the next page, the Papyrus of Ani. The Hunefer's papyrus is also very famous by depicting this Hall of Judgement scene.

${ }^{536}$ For a wider detail of the papyrus, see figure 16 in the appendix. There, the couple Ani and Tutu are also depicted. In Eternal Egypt, the scene is described as follows: "Into this formidable gathering comes Ani, accompanied by his wife Tutu. They enter from the left, bending forward in proper humility, and Ani mutters the words of Spell 30B of the Book of the Dead, which are addressed to his heart in the balance: 'My mother, heart of my mother, heart of my forms, do not stand against me as a witness, do not oppose me in the tribunal, do not turn away from me in the presence of the controller of the balance. You are my $k a$, which was in my body... [my highlights]". RUSSMANN, E. Eternal Egypt, p. 199.

${ }^{537}$ If the life of the person mirrored truth, he will be rendered to "the very power of existence". Otherwise, Ammit, a hybrid of crocodile, hippopotamus and lion, that waits close to the scale, will devour his heart. The ibis-headed man close to Ammit is Thoth, who is "the scribe of the gods, and he holds a scribe's palette and a reed brush, ready to note down the results of Ani's interrogation". $B a$ bird represents Ani's soul. It will "allow him freedom of movement (...) after death (...) if judgment is given in Ani's favor". The other deities that appear in the papyrus are "Shay (fate) and (...) Renenutet and Meskhenet", the goddess of nourishment and the goddess of childbirth, respectively. In: RUSSMANN, E. Eternal Egypt, p. 199.
} 


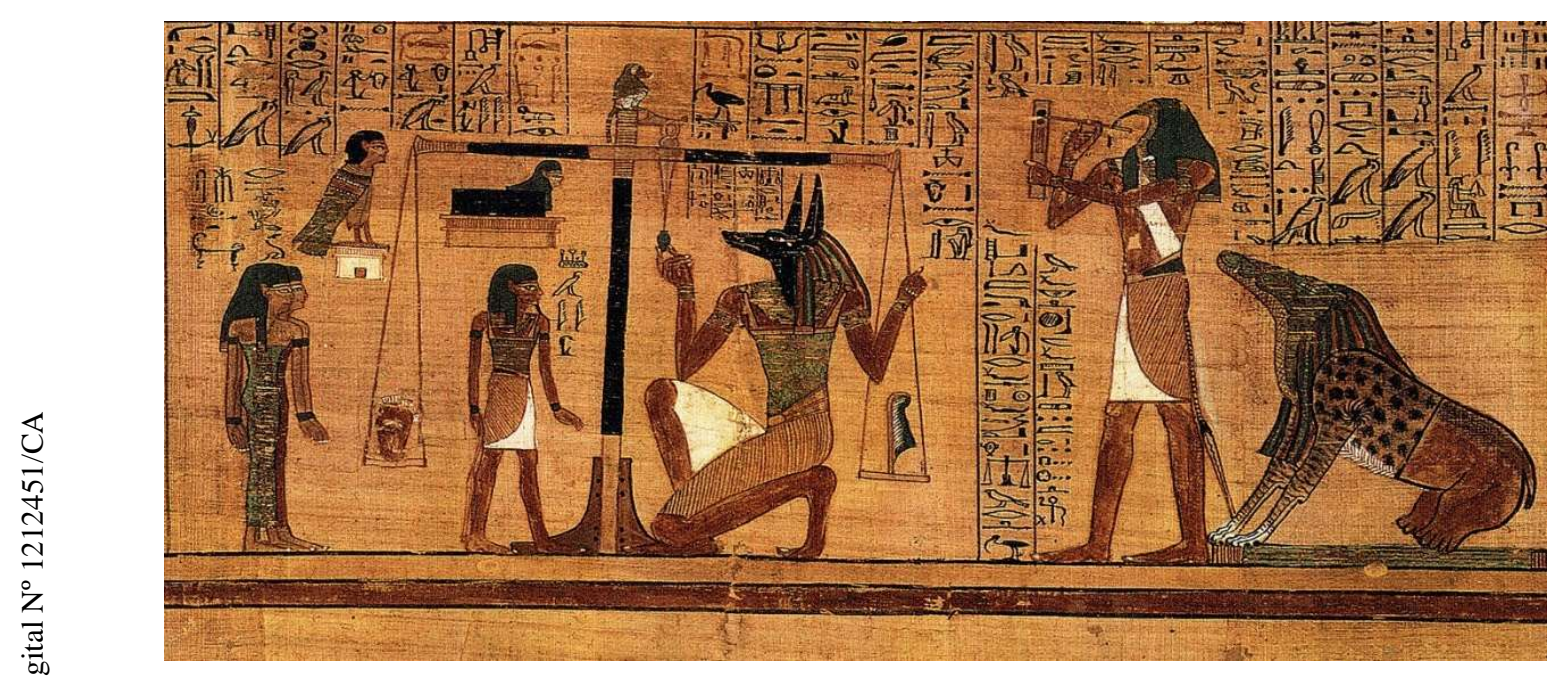

Figure 5

"Weighing of the heart", detail from the Book of the Dead Original artist unknown. c. 1275 B.C.

British Museum, London. 
There is not an overlap between the Greek and the Egyptian traditions, nor between the latter and Heidegger's thought. Nevertheless, as Bailly says, a link could be traced between the Egyptian representation of the not representable and the Greek sudden visibility of the invisible. Thus, it could be added, that it could also be traced a link between this sudden visibility of the invisible or the representation of the not representable and Heidegger's sudden unapparent appearing of the mutual belonging of concealment and unconcealment. This means to trace a link to the instant in which the incessant rise of physis shines in brilliance. They all seem to address somehow a transformation from death to a new inception. They all address the instant of a transformation. Thus, they all seem to address this instant in which the human being, measuring itself with the divine, builds a temple. Such measuring makes him divine, as the one who echoes truth.

Making himself divine, the human being lets enowning happen. This sudden gathering brings man to dwelling in the unapparent, in the nameless. Thus, human being "must first learn to exist in the nameless. (...) Only thus will the pricelessness of its essence be once more bestowed upon the word, and upon humans a home for dwelling in the truth of being" ${ }^{\text {"538. }}$. As Heidegger says, the image (Bild) is "the appearing of the time-space-play [Zeit-Spiel-Raumes]" ${ }^{, 539}$. As already said, the remembrance of the incessant rise of physis arises in an instant, which, as such memory, becomes an altar. Such time-space-play might be thought then as an instant-space-play, the altar-unapparent ${ }^{540}$ play, that is: the altar-temple play, which is "the site (Ort)". It is the site where the sacrifice of the Mass is celebrated. It is the altar as the memory of this play. It is the site which is also the play itself. Thus, it appropriates itself, as such, it is enowning (Ereignis). The image (Bild) as Altar-Bild is enowning (Ereignis). Nevertheless, it needs human being's renouncing in order to authentically shine as Altar-Bild, as enowning (Ereignis).

\footnotetext{
538 "Letter on 'humanism'”, p. 243. Original: “muß (...) zuvor lernen, im Namenlosen zu existieren (...) Nur so wird dem Wort die Kostbarkeit seines Wesens, dem Menschen aber die Behausung für das Wohnen in der Wahrheit des Seins wiedergeschenkt". GA 9 [150-151], p. 319. ${ }^{539}$ My translation. Original: "Das Bild ist das Scheinen des Zeit-Spiel-Raumes". GA 13, p. 121.

${ }^{540}$ According to the previous chapter, the space is the dimension, the unapparent openness. In this chapter, it has been argued that the belonging to a church is a belonging to the unapparent, once Heidegger himself says that the site is an unapparent site.
} 
Mastery, Hölderlin sings: "Reluctant to leave the place $[O r t] /$ Is that which dwells near the origin" ${ }^{541}$. Its beauty delights. One of Heidegger's final remarks in his text On the Sistine Madonna is that "The truth of the image [Bild] is its beauty" 542 . Raphael claimed that the beautiful was nothing but "the sense of integration between the space and the figure" [my highlight $]^{543}$. Beauty, for Heidegger, is also related to a mutual belonging. It has been discussed that the image $[$ Bild $]$ is a bringing into emergence of an unapparent appearing of the incessant rise of physis as a building a temple. This bringing into emergence of the brilliant shine of physis is the beauty of the image. But it is important to stress that "Beauty does not occur alongside (...) truth. It appears when truth sets itself into the work. This appearing (as this being of truth in the work and as the work) is beauty. Thus beauty belongs to the advent of truth [my highlight]" as its authentic shine. As Heidegger says in Origin of the work of art: "The shining that is set into the work is the beautiful. Beauty is one way in which truth as unconcealment comes to presence ${ }^{" 545}$. In order to mirror this beauty, we must open ourselves to a transformation from inauthenticity (Un-eigentlichkeit) into authenticity (Eigentlichkeit), from death into a new beginning.

\footnotetext{
${ }^{541}$ Apud OWA, p. 50. Original: ">> Schwer verläßt / Was nahe dem Ursprung wohnet, den Ort. $<<"$. GA 5 [65], p. 66.

542 My translation. Original: "Die Wahrheit des Bildes ist seine Schönheit". GA 13, p. 121.

${ }^{543}$ My translation. ARGAN, G., Clássico anticlássico: o Renascimento de Bunelleschi a Bruegel, p. 288. The original was not available.

544 OWA, p. 52. Original: "Die Schönheit kommt nicht neben (...) Wahrheit vor. Wenn die Wahrheit sich in das Werk setzt, erscheint sie. Das Erscheinen ist - als dieses Sein der Wahrheit im Werk und als Werk - die Schönheit. So gehört das Schöne in das Sichereignen der Wahrheit". GA 5 [67], p. 69.

${ }^{545}$ OWA, p. 32. Original: "Das ins Werk gefügte Scheinen ist das Schöne. Schönheit ist eine Weise, wie Wahrheit als Unverborgenheit west". GA 5 [44], p. 43.
} 


\section{4 \\ Final remarks}

What you have achieved cannot signify more to others than to you ${ }^{546}$.

Ludwig Wittgenstein

In La Peau de chagrin Balzac describes a 'tablecloth white as a layer of newly fallen snow, upon which the place-settings rise symmetrically, crowned with blond rolls.' 'All through youth,' said Cezanne, 'I wanted to paint that, that tablecloth of new snow.... Now I know that one must will only to paint the place-settings rising symmetrically and the blond rolls. If I paint 'crowned' I've had it, you understand? But if I really balance and shade my place-settings and rolls as they are in nature, then you can be sure that the crowns, the snow, and all the excitement will be there too ${ }^{, 547}$.

Maurice Merleau-Ponty

It is no news that thinking belongs to being or even that it thinks being. It wouldn't be pioneer either to relate such understanding of thinking to the unfolding of the world. It would also be a standard interpretation to say that, for Heidegger, thinking is the disclosure of appropriation (Ereignis) as the being being. What is at stake here is not originality but originarity. It is a matter of trying to co-respond to thinking, making being appear in the Sistine Madonna ${ }^{548}$. The effort to be originary is the effort, as Rodin would call it, of conquering an inheritance ${ }^{549}$. It is the effort of trying to make our own what belong to our forefathers, to make our legacy rise again. Co-respondance, in this light, would

${ }^{546}$ WITTGENSTEIN, L. Culture and value, p. 15. Original: "Was Du geleistet hast kann Andern nicht mehr bedeuten als Dir selbs".

${ }^{547}$ MERLEAU-PONTY, M. "Cézanne's doubt", p. 16. Original: "Balzac décrit dans La Peau de Chagrin une " nappe blanche comme une couche de neige fraîchement tombée et sur laquelle s'élevaient symétriquement les couverts couronnés de petits pains blonds ». "Toute ma jeunesse, disait Cézanne, j'ai voulu peindre ça, cette nappe de neige fraîche... Je sais maintenant qu'il ne faut vouloir peindre que s'élevaient symétriquement les couverts, et: de petits pains blonds. Si je peins " couronnés ", je suis foutu, comprenez-vous? Et si vraiment j'équilibre et je nuance mes couverts et mes pains comme sur nature, soyez sûrs que les couronnes, la neige et tout le tremblement y seront. »". In: "La doute de Cézanne", p. 23.

${ }^{548}$ Which also means: here in the light of Heidegger remarks.

${ }^{549}$ See Les Cathédrales de France. 
not be then an imitation or understood in a metaphysical way ${ }^{550}$, but rather responding together with our ownmost constitution, echoing it, echoing its song. It would be cor-respondance, responding with our hearts.

According to Heidegger, "To accomplish means to unfold something into the fullness of its essence, to lead it forth into this fullness -producere. Therefore only what already is can really be accomplished. But what 'is' above all is being" "551. Being enowns itself in poetry, in the speaking in images, as measuring. In poetry, the conquest of the measure discloses itself in self-appropriation. "That [measuring] consists in man's first of all taking the measure which then is applied in every measuring act" ${ }^{\prime 552}$. Taking the measure means here conquering the measure. This conquest is letting the measure echo through you. Through this authentic dwelling, it enowns itself.

I have tried to maintain the conductor thread of this dissertation tensioned as the tension of the bow and the lyre. Bowing, we tension the chord. This was an attempt to make the words hold the possibility of sounding a reverent sing when encountering a dwelling place able to play this tensioned chord. Heidegger gives his testimony on his own attempts:

It has happened to me more than once, and indeed precisely with people close to me, that they listen gladly and attentively to the presentation of the jug's nature, but immediately stop listening when the discussion turns to objectness, the standing forth and coming forth of production - when it turns to framing. (...)

Among the curious experiences I have had with my lecture is also this, that someone raises the question as to whence my thinking gets its directive, as though this question were indicated in regard to this thinking alone. (...)

But maybe someday the answer to these questions can be gained from those ventures of thought which, like mine, look as though they were lawless caprice.

I can provide no credentials for what I have said $(\ldots)^{553}$.

\footnotetext{
${ }^{550}$ Which Heidegger has many times explicitly criticized.

551 "Letter on 'humanism"”, p. 239. Original: "Vollbringen heißt: etwas in die Fülle seines Wesens entfalten, in diese hervorgeleiten, producere. Vollbringbar ist deshalb eigentlich nur das, was schon ist. Was jedoch vor allem $>>$ ist <<, ist das Sein". GA 9 [145], p. 313.

552 “...Poetically Man Dwells...”, p. 129. Original: "Er besteht darin, daß überhaupt erst das Maß genommen wird, womit jeweils zu messen ist.”. GA 7 [190], p. 200.

553 "Epilogue" in "The Thing", p. 183-184. Original: "Öfter schon begegnete es mir und zwar gerade bei nahestehenden Menschen, daß man sehr gern und aufmerksam auf die Darstellung des Krugwesens hört, daß man aber sofort die Ohren verschließt, wenn von Gegenständlichkeit, Herstand und Herkunft der Hergestelltheit, wenn vom Gestell die Rede ist. (...) / Zu den seltsamen
} 
Despite not been able to give credentials either, I can try to clarify a few choices, or at least the main one. Concerning the deepening on discussions on what is not the originary Bild or how it was misunderstood, for example, I would say that I have chosen to focus on the extra-ordinary, on how the ordinary might shine in brilliance. The following passage is cryptical on the kind of path I tried to pursue:

In the course of their journey he came to a village, and a woman named Martha welcomed him into her house. She had a sister called Mary, who sat down at the Lord's feet and listened to him speaking. Now Martha who was distracted with all the serving said, 'Lord, do you not care that my sister is leaving me to do the serving all by myself? Please tell her to help me.' But the Lord answered: 'Martha, Martha,' he said, you worry and fret about so many things, and yet few are needed, indeed only one. It is Mary who has chosen the better part; it is not to be taken from her. ${ }^{554}$

The only thing authentically needed is what is not needed. Heidegger himself says: that we are poor once "we are deprived of nothing except" 555 one thing: "what is not needed"556 that is: "what does not arise out of a need" ${ }^{557}$ as, I add, Martha's occupations. I have tried to focus on what is not needed, the only authentic privation.

The Sistine Madonna is, according to Heidegger, a unique image essencing (Bildwesen). In it, the "Bild bildet", the image forms, the bringing into emergence (her-vor-bringen) brings into emergence, both: a window and a site. The Sistine is a site of alétheia. The window is a unique out-look as a glance toward the mutual bringing of Mother and Son, which also refers to a mutual belonging of

Erfahrungen, die ich mit meinem Vortrag mache, gehört auch die, daß man mein Denken danach befragt, woher es seine Weisung empfange, gleich als ob diese Frage nur gegenüber diesem Denken nötig sei. (...) / Aber vielleicht läßt sich eines Tages die Antwort auf diese Fragen gerade denjenigen Denkversuchen entnehmen, die wie die meinen sich als gesetzlose Willkür ausnehmen. / Ich kann Ihnen (...) keine Ausweiskarte liefern (...) das von mir Gesagte". GA 7 [178], p. 186187.

${ }^{554}$ Luke 10, 38-42.

555 "Poverty", p. 6. Original: "wir nichts entbehren, es sey denn". GA 73, p. 877.

556 "Poverty", p. 6. Original: "das Unnötige”. GA 73, p. 878.

557 "Poverty", p. 7. Original: "was nicht aus der Not kommt”. GA 73, p. 878. 
concealment and unconcealment. The mutual belonging of the Mother and the Son faces the image forming a window as the openness of a disclosure, which also refers to a mutual belonging of concealment and unconcealment. I have suggested that this mirroring addresses a disclosure of appropriation (Ereignis). It addresses the issue of the unapparent appearing of the mutual belonging of concealment and unconcealment facing itself. This issue might be investigated through Heidegger's characterization of the word image (Bild) as meaning countenance (Antlitz) and through his characterization of this image (Bild) as an Altar-Bild.

In the first chapter, I have discussed Heidegger's characterization of the image (Bild) as countenance (Antlitz) through his specification of the meaning of 'countenance' (Antlitz) as an "en-countering glance" (Entgegenblick). I have addressed the mutual bringing of Mother and Son as related to the invisible horizon of a mutual belonging that incessantly rises. This arrival of a mutual bringing is related to the mutual belonging of concealment and unconcealment as a peculiar provenience of all being. The word 'countenance' (Antlitz) is related to the meaning of face as prósopon, which might mean mask and persona, for example. They are both meanings related to that which sounds through, a personare, as, in the case of the mask, the voice sounding through it. I have suggested that the funerary mask inspires the remembrance of that which sounds through everything. It does not represent the dead, but the life of the dead, as the incessant rise inherent to all appearing, be it authentically or inauthentically.

It was also important to stress that the kind of face-to-face being addressed is not one of subject and object. It is an appropriation of the unapparent by itself, which authentically happens through human being. The mystery (Geheimnis) is the mutual belonging of concealment and unconcealment in a thing. It might be associated to the mountain as being both: the rising ground and the barrow. Such mutual belonging of concealment and unconcealment traverses everything. This ownmost of things enowns itself through thinking as a thinking of being that listening to being, sheltering it.

The characterization of the Sistine as an Altar-Bild is also a way of thinking the disclosure of appropriation (Ereignis). The intrinsic relation of the Sistine as image (Bild) to a church refers to the sheltering way in which Being gathers itself. The altar is the site of the remembrance of the sacred as the making shine in brilliance the incessant rise of physis. As the site of Eucharistic, it is a site 
of praise and thanksgiving. It is a site where man offers his heart, stepping back before truth as alétheia. This reverent bow is a renouncing in which he makes room to let truth echoes. This openness shelters truth, preserving it in its ownmost. Thus, it is the site of a transformation into a making shine in brilliance as a transformation from inauthenticity (Un-eigentlichkeit) to authenticity (Eigentlichkeit). It is then a transformation in which there is an appropriation of the ownmost of things as a disclosure of appropriation (Er-eignis).

A thing, as that which is mysterious, holds the mutual bringing of concealment and unconcealment. As such, it is the occasion for a transformation as the bringing forth of the gathering of its ownmost in brilliance. Art as techne and language as poetic language are such gathering inherent to the disclosure of appropriation as the unapparent appearing of the incessant rise of physis. The enowning brings into emergence (her-vor-bringen) the site as the unapparent and the nameless, building an altar. As remembrance, the altar is the appearing of the time-space-play (Zeit-Spiel-Raumes) as the sudden emergence of the shine in brilliance. It is that instant in which the openness enowns itself.

According to Heidegger, art is itself an enigma (Rätsel). My task was "far from claiming to solve the enigma" 558 . As Heidegger defends, "The task is to see

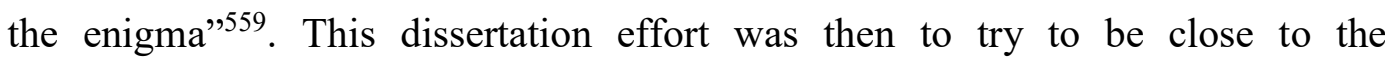
mysterious (Geheimnis) character of a thing. As it has been elucidated in the chapter on the Altar-Bild, to echo the mystery of a thing is not to say it, because it is nameless. It is rather the way by which it is said: by a safeguarding that preserves the thing in its ownmost.

"What remains for thinking is only the simplest saying of the simplest image $[$ Bildes] in purest reticence" $\$ 560$. The Sistine Madonna mirrors what we bet on it. If we like to take it as an object, it will be a work of art. If we like to take it as an originary Bild, it will correspond to it. How much are we ready to bet? How much are we prepared to give up in order to make room for a hearing? Are we brave enough for the depth and the height of its mystery (Geheimnis)? Are we worthy of its pure reticence?

\footnotetext{
${ }^{558}$ OWA, p. 50. Original: "Das Anspruch liegt fern, das Rätsel zu lösen”. GA 5 [66], p. 67.

${ }^{559}$ OWA, p. 50. Original: “Zur Aufgabe steht, das Rätsel zu sehen”. GA 5 [66], p. 67.

560 From enowning, p. 50. Original: "Dem Denken bleibt nur das einfachste Sagen des schlichtesten Bildes in reinster Verschweigung”. GA 65, p. 72.
} 
If Wittgenstein is right and "what we have achieved cannot signify more to others than to ourselves", then I hope that this work has truly transformed me, that it will continually help me to be a better per-son ${ }^{561}$. If it is an even more blessed work, it will help others to also open themselves to an incessant transformation.

For it does not admit of exposition like other branches of knowledge, but after much converse about the matter itself and a life lived together, suddenly a light, as it were, is kindled in one soul by a flame that leaps to it from another, and thereafter sustains itself ${ }^{562}$.

Making mine Heidegger's wish, I say: "May the legacy, that has gathered itself in centuries of earthly and heavenly powers of our homeland, stay awake in you"563.

\footnotetext{
561 "But because many endeavor rather to get knowledge than to live well; therefore they are often deceived, and reap either none, or very slender profit". KEMPIS, T. The Imitation of Christ, p. 33. Original: "quia student magis plures scire quam bene vivere, ideo sæpe errant, et nullum vel modicum fructum ferunt". In: KEMPIS, T. Imitatione Christi, I, 3, 4.

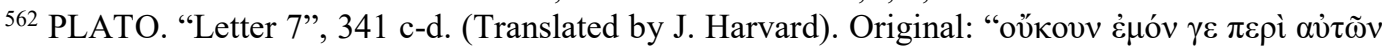

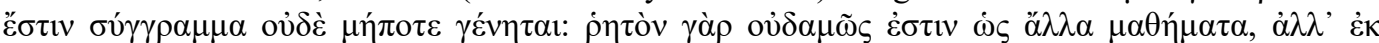

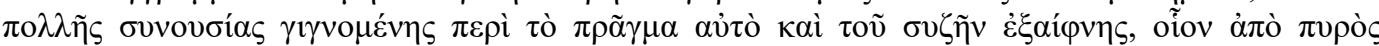

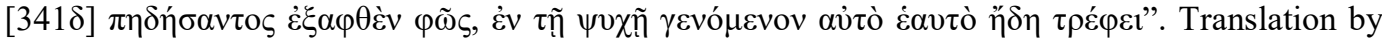
R. G. Bury: "For it does not at all admit of verbal expression like other studies, but, as a result of continued application to the subject itself and communion therewith, it is brought to birth in the soul on a sudden, as light that is kindled [341d] by a leaping spark, and thereafter it nourishes itself".

563 My translation. Original: "Möge das Erbe, das sich in Jahrhunderten an irdischen und himmlischen Kräften unserer Heimat gesammelt hat, in Dir wach bleiben”. GA 16, p. 490.
} 


\section{Glossary}

This glossary is a list of the most important words discussed on this dissertation with the indications of the most usual translations available. The intent was also to give, when convenient, a few bibliographical support on where to find the suggested translations or discussions on the choices made.

German- English

A

Antlitz - countenance ${ }^{564}$, semblance ${ }^{565}$, face.

B

Bild - image, picture, form, bringing into emergence, originary mímesis ${ }^{566}$.

$\mathbf{E}$

Eigentlich - authentic ${ }^{567}$. (Uneigentlich - unauthentic).

Ereignis - disclosure of appropriation ${ }^{568}$, enowning. The following alternatives were criticized: event, event of appropriation, appropriation, befitting $^{569}$.

\footnotetext{
${ }^{564}$ See Kluge. See also RADLOFF, B. Preliminary notes on divine images, p. 155.

565 See Experiencias del pensar, p. 81. Semblance is closer to the meaning of vraie semblance proposed by Lacoue-Labarthe as a way to understand the Bild.

566 See LACOUE-LABARTHE, P. La vraie semblance.

${ }^{567}$ See Inwood, p. 22-24 and BT [42].

${ }^{568}$ See PLT, p. xxi. Translation approved by Heidegger himself.

${ }^{569}$ See Contributions to philosophy, p. xix-xxi.
} 
Entgegenblick - a glance turned toward ${ }^{570}$; en-countering looking ${ }^{571}$; encountering glance.

G

Geheimnis - mystery.

H

Heimat - homeland, native land.

Heimlich - familiar ${ }^{572}$, habitual, private, concealed, domestic.

Heimisch - homely, domestic (einheimisch - at home $)^{573}$.

$\mathbf{U}$

Unheimlich - uncanny, unfamiliar, strange ${ }^{574}$ as that which is not habitual.

W

Wesen - essencing ${ }^{575}$, (Anwesen) presencing $^{576}$.

$\mathbf{Z}$

Zusammengehörikeit - belonging together, mutual belonging.

Zwischen - in-between. In a few translations, it appears as just 'between'.

Zwischen-Fall - in-cident ${ }^{577}$, literally, fall-between.

${ }^{570}$ See "Language in the poem", p. 185.

${ }^{571}$ See RADLOFF, B. Preliminary notes on divine images, p. 155.

${ }^{572}$ See Carneiro Leão's translation of Introduction to metaphysics, p. 174, GA 40 [116].

${ }^{573}$ See note 58 in IM, p. 161.

${ }^{574}$ See note 57 in IM, p. 160.

${ }^{575}$ See Marcia's note 1 in her translation of "Language" to Portuguese.

576 See HERNANDEZ, J. How presencing (Anwesen) became Heidegger's conception of Being.

577 See IM, p. 174. GA 40 [125]. See also note 67. 


\section{References}

ANTOGNAZZA, M. R. "Leibniz de Deo Trino: philosophical aspects of Leibniz's conception of the Trinity". In: Religious studies. Cambridge. Vol. 37 , issue 01, march 2001, p. 1-13.

ARGAN, G. Clássico anticlássico: o Renascimento de Bunelleschi a Bruegel. Translated by Lorenzo Mammì. São Paulo: Companhia das Letras, 1999.

ARISTOTLE. De Partibus Animalium I and De generatione animalium I. Translated with notes by D. M. Balme. New York, Clarendon Press, 2003.

A VIEW ON CITIES. Available at <http://www.aviewoncities.com/img/mila $\mathrm{n} / \mathrm{kveit3428s.jpg}>$. Access in 10/18/2017.

BAILLY, J. L'apostrophe muette: essais sur le portraits du Fayoum. Paris: Hazan, 1997.

BARACCHI, C. "Contributions to the Coming-to-Be of Greek Beginnings: Heidegger inceptive thinking". In: Heidegger and the Greeks: interpretive essays. Edited by Drew A. Hyland and John P. Manoussakis. USA: Indiana University Press, 2006. p. 23-42.

BEAUFRET, J. "Heidegger et la théologie". In: KEARNEY, R. \& O'LEARY, J. Heidegger et la question de Dieu. Paris: Bernard GRASSET, 1990, p. 19-36.

"Heraclitus and Parmenides". In: MALY, K. \& EMAD, P. Heidegger on Heraclitus: a new reading. Lewiston \& Queenston: The Edwin Mellen Press, 1986, p. 69-88.

BECKER, K. 'Die Sixtinische Madonna': Historische Umstände und künstlerische Wirkung. Germany: Grin, 2013.

BELTING, $\mathrm{H}$. Likeness and presence: a history of the image before the era of art. Translated by Edmund Jephcott. Chicago and London: The University of Chicago Press, 1994.

BENJAMIN, W. Gesammelte schriften I. Editors: R. Tiedemann and $\mathrm{H}$. Schweppenhäuser. Frankfurt: Suhrkamp, 1981. 
. "The work of art in the age of its technological reproducibility: third version". In: EILAND, H.; JENNINGS, M. W. (Editors). Walter Benjamin: selected writings. Volume 4, 1938-1940. USA: Harvard University Press: 2006, p. 251-283.

The work of art in the age of its technological reproducibility and other writings on media. Editors: $M$. Jennings, $B$. Doherty and T. Levin. Cambridge and London: Belknap Press, 2008.

BÍBLIA. English. The Jerusalem Bible: the reader's edition. General Editor: Alexander Jones. Garden City, New York: Doubleday \& Company, Inc., 1968.

. Portuguese. Bíblia de Jerusalém. São Paulo: Paulus, 2010.

BIRAULT, H. Heidegger et l'expérience de la pensée. Paris: Gallimard, 1978.

BOEDER, H. "Dissesions". In: MALY, K. \& EMAD, P. Heidegger on Heraclitus: a new reading. Lewiston \& Queenston: The Edwin Mellen Press, 1986, p. 167-177.

BOEHM, G. "Representation, presentation and presence: tracing the homo pictor". In: ALEXANDER, J. \& BARTMANSKI, D. \& GIESEN, B. (ed.) Iconic power: materiality and meaning in social life. New York: Palgrave Macmillan, 2012, p. 15-24.

BONFIM, P. " 'Ó fogo eterno, ó fonte do amor' 'Padre Antônio Vieira e o misticismo da carne". In: Analógos XI - Anais da XI SAF PUC. Rio de Janeiro, 2011, p. 225.

BORGES, J. Poesia. Translated by Josely Vianna Baptista. São Paulo: Companhia das Letras, 2009.

BORGES-DUARTE, I. Arte e técnica em Heidegger. Lisboa: Documenta, 2014.

BORRIELLO, L.; CARUANA, E.; DEL GENIO, M. R.; SUFFI, N. (org.) Dicionário de mística. Translated by Benôni Lemos, José Maria de Almeida, Silva Debetto Cabral Reis, Ubenai Lacerda Fleuri. São Paulo: Paulus, Edições Loyola, 2003.

BRANDÃO, J. Mitologia grega. Vol. 1. Petrópolis: Editora Vozes, 2007.

BRITISH MUSEUM. Available at <http://www.britishmuseum.org/whatso n/all_current_exhibitions/book_of_the_dead.aspx>. Access in 10/18/2017.

BURNET, J. Early Greek Philosophy. London: A \& C Black, 1920. 
CAPOBIANCO, R. Heidegger on Hebel: the inexhaustible depth of things. Available at https://www.beyng.com/docs/Richard\%20Capobianco \%20-\%20Heidegger\%20on\%20Hebel.pdf in 10/18/2017.

CAPUTO, J. "Heidegger and theology". In: The cambrigde companion to Heidegger. Edited by Charles Guignon. USA: Cambridge University Press, 1993. p. 270-288.

"The mystical element in Heidegger's thought". In: Journal of the History of Philosophy. v. XIII. no 1 . January. 1975, p. 61-80.

CHANTRAINE, P. Dictionnaire étymologique de la langue grecque. Histoire des mots. Paris: Éditions Klincksieck, 1968.

CHEVALIER, J. \& GHEERBRANT, A. Dictionnaire des symboles. Paris: Éditions Robert Laffont S. A. \& Éditions Jupiter, 1982.

CHIESA CATTOLICA. Available at <http://www2.chiesacattolica.it/ ceidocs/seed/bd_arte_dioc.page?p_id=151\&flag_sez=3\&id_page $=34>$. Access in 10/18/2017.

COMUNE DI PIACENZA. Available at <https://www.comune.piacenza.it/ welcome/the-city/what-to-see/church/san-sisto-church>. Access in 10/18/2017.

CUNNINGHAM, L. Mother of God. San Francisco: Harper \& Row, 1982.

DA VINCl, L. An Old Man and a Youth Facing One Another. About 1500-1505. Red chalk on paper. Galleria degli Uffizi, Gabinetto dei Disegni e delle Stampe, Florence, Italy.

DAVIS, S. "Philosophy in its originary Pre-metaphysical sense". In: MALY, K. \& EMAD, P. Heidegger on Heraclitus: a new reading. Lewiston \& Queenston: The Edwin Mellen Press, 1986, p. 155-166.

DERUN, Z. Primordial Caos. 1349. Ink on paper. Height: 29.7 x Width: 86.2. Shanghai Museum, China. Available at www.shanghaimuseum.net /museum/frontend/collection/zoom .action?cplnfold=1059\&picld=2323 in 10/09/2017.

DUQUE-ESTRADA, P. C. "Sobre a Obra de Arte como Acontecimento da Verdade". In: 0 que nos faz pensar. n.13. Rio de Janeiro: publicação do Departamento de Filosofia da PUC-RJ, 1999. p. 67-78.

EBERLEIN, J. "The Curtain in Raphael's Sistine Madonna". In: Art Bulletin. 65.1. 1983, p. 61-77.

EMAD, P. "Heidegger's originary reading of Heraclitus fragment 16". In: MALY, K. \& EMAD, P. Heidegger on Heraclitus: a new reading. Lewiston \& Queenston: The Edwin Mellen Press, 1986, p. 103-123. 
"Word at the beginning of thinking". In: MALY, K. \& EMAD, P. Heidegger on Heraclitus: a new reading. Lewiston \& Queenston: The Edwin Mellen Press, 1986, p. 124-133.

FATTAL, M. Image, mythe, logos et raison. Paris: L'Harmatttan, 2009.

FÉDIER, F. "Heidegger et Dieu". In: Heidegger et la question de Dieu. Recueil préparé sous la direction de Richard Kearney et Joseph Stephen O'Leary. Paris: Bernard Grasset, 1980, p. ?.

FERRY, L.; RENAULT, A. "La question de l'éthique après Heidegger". In: Système et critique: essays sur la critique de la raison dans la philosophie contemporaine. 2. ed. Bruxelles: Ousia, 1992.

FRÉMONT, C. “L'Être et la relation”. In: FRÉMONT, C. (éd.) L’Être et la relation: letters de Leibniz à des Bosses. Paris: Vrin, 1999.

FINK, E. "Vergegenwärtigung und Bild. Beiträge zur Phänomenologie der Unwirklichkeit". In: Studien zur Phänomenologie. 1930-1939. (Phaenomenologica, 21). Nijhoff: Den Haag, 1966, p. 74-78.

FOGEL, G. O homem doente do homem e a transfiguração da dor: uma leitura de 'Da visão e do enigma' em Assim falava Zaratustra, de Frederico Nietzsche. Rio de Janeiro: Mauad X, 2010.

FREEDBERG, D. The power of images: studies in the history and theory of response. Chicago and London: The University of Chicago Press, 1989.

GOMBRICH, E. H. The story of art. London: Phaidon Press, 1995.

HAAR, M. Heidegger and the essence of man. Translated by William McNeill. Albany: State University of New York Press, 1993.

HAAR, M. The song of the earth: Heidegger and the grounds of the history of being. Translated by R. Lilly. Bloomington: Indiana University Press, 1993.

HAMACHER, W. "Le dépouillement: expositions de la mère". Translated by Marc Froment-Meurice. In: Po\&sie. n. 73. Paris; Berlin, 1995, p. 95113.

HEAR, M. "Painting and Calligraphy under the Mongols". In: WATT, J. The World of Khubilai Khan: Chinese Art in the Yuan Dynasty. New Haven and London: Yale University Press, 2010, p. 181-240.

HEIDEGGER, M. "700 Jahre Meßkirch". In: Zum 80. Geburstag von seiner Heimatstadt Messkirch. Frankfurt am Main: Vittorio Klostermann, 1969, p. 34-45. 
. "Anaximander's saying (1946)". In: Off the beaten track.

Translated by Julian Young and Kenneth Heynes. Cambridge, UK: Cambridge University Press, 2002, p. 242-281.

. "Art and space". In: SALLIS, J. (org.) The Heidegger reader. Translated by Jerome Veith. Bloomington \& Indianopolis: Indiana University Press, 2009, p. 305-309.

Basic Questions of Philosophy: Selected "Problems" of "Logic" (GA 45). Translated by Richard Rojcewicz and Andre Schuwer. Bloomington: Indiana University Press, 1994.

. Being and time. (GA 2). Translated by Joan Stambaugh. Albany: State University of New York Press, 2010.

Being and Truth (GA 36/37). Translated by Gregory Fried and Richard Polt. Bloomington: Indiana University Press, 2010.

Beiträge zur Philosophie (Von Ereignis) (GA 65). Frankfurt am Main: Vittorio Klostermann, 1989.

Bremen and Freiburg Lectures: insight into that which is and basic principles. Translated by Andrew J. Mitchell. Bloomington \& Indianapolis: Indiana University Press, 2012.

. "Bremen Lectures: insight into that which is". In: SALLIS, J. (org.) The Heidegger reader. Translated by Jerome Veith. Bloomington \& Indianapolis: Indiana University Press, 2009, p. 253-283.

. "Building Dwelling Thinking" (GA 7). Poetry, language, thought. Translated by Albert Hofstadter. New York: Harper \& Row, 1971, p. $141-160$.

Caminhos de Floresta. Translated by João Constâncio, Irene Borges Duarte. Lisboa: Calouste Gulbenkian, 2002.

. Carta sobre o Humanismo. Translated by Emmanuel Carneiro Leão. Rio de Janeiro: Tempo Brasileiro, 1995.

"Cézanne". In: SALLIS, J. (org.) The Heidegger reader. Translated by Jerome Veith. Bloomington \& Indianopolis: Indiana University Press, 2009, p. 310-312.

. Dall'esperienza dell pensiero 1910- 1976. Translated by Nicola Curcio. Genova: II melangolo, 2011.

- "Die Herkunft der Kunst und die Bestimmung des Denkens". Available at http://www.eudia.org/wp/download.php?id=1142 in 09/22/2017. 
Discourse on Thinking (GA 16). Translated by John M. Anderson and E. Hans Freund. New York: Harper and Row, 1966.

. "Ereignis". In: SALLIS, J. (org.) The Heidegger reader. Translated by. Jerome Veith. Bloomington \& Indianopolis: Indiana University Press, 2009, p. 177-188.

Experiencias dell pensar (1910-1976). Translated by Francisco de Lara. Madrid: Abada editores, 2014.

Gesamtausgabe (GA). Frankfurt am Main: Vittorio Klostermann, several years.

Heráclito: a origem do pensamento ocidental: lógica: a doutrina heraclítica do lógos. Translated by Marcia Sá Cavalcante Schuback. Rio de Janeiro: Relume Dumará, 1998.

Identity and Difference (GA 11). Translated by Joan Stambaugh. New York: Harper \& Row, 1969.

. Introduction to metaphysics (GA 40). Translated by Gregory Fried and Richard Polt. New Haven and London: Yale University Press, 2000.

. "Letter on humanism". In: MCNEILL, W. (ed). Pathmarks (GA 9). Translated by Frank A. Capuzzi. Cambridge: Cambridge University Press, 1998.

"Logos and language". In: SALLIS, J. (org.) The Heidegger reader. Translated by Jerome Veith. Bloomington \& Indianopolis: Indiana University Press, 2009, p. 239 -252.

. "On the essence of ground". In: MCNEILL, W. (ed). Pathmarks (GA 9). Translated by W. McNeill. Cambridge: Cambridge University Press, 1998.

. On the way to language (GA 12). Translated by Peter Hertz and Joan Stambaugh. USA: Harper \& Row, 1971.

Origem da obra de arte. Translated by Idalina Azevedo e Manuel António de Castro. São Paulo: Edições 70, 2010.

. "...Poetically man dwells..." (GA 7). Poetry, language, thought. Translated by Albert Hofstadter. New York: Harper \& Row, 1971, p. 209-227.

. "Poverty". In: SCHALOW, F. Heidegger, translation and the task of thinking: essays in honor of Parvis Emad. New Orleans: Springer, 2011. 
Reden und andere Zeugnisse eines Lebensweges

(GA 16). Frankfurt am Main: Vittorio Klostermann, 2000.

"Messkirch's Seventh Centennial". Translated by T. Sheehan. In: Listening, VIII, 1-3 (1973), 40-57.

. "Sobre a Madonna Sistina". In: Mímesis e expressão. Orgs. Rodrigo Duarte e Virginia Figueiredo. Belo Horizonte: Ed. UFMG, 2001. p. 21-23.

. "Sobre a Madonna Sixtina". In: Arte como epifania In: Filosofia. Lisboa, III, 1989, p. 74-77. Available at http://www.martinheidegger.net/Textos/html/Sobre\%20a\%20Madonna\%20Sixtina.html in 12/31/2015.

. "Sprache und Heimat". In: Aus der Erfahrung des Denkens - 1910-1976. (GA 13). Frankfurt am Main: Vittorio Klostermann, 1983, p. 155-180.

Mavridis. In: Po\&sie. N. 81. September 1997. Paris, p. 4-8.

. "The age of the world picture". In: SALLIS, J. (org.) The Heidegger reader. Translated by Jerome Veith. Bloomington \& Indianopolis: Indiana University Press, 2009, p. 207-223.

"The Anaximander fragment". In: Early greek thinking. Translated by David F. Krell and Frank A. Capuzzi. New York: Haper \& Row, 1984.

. The basic problems of phenomenology. (Winter Semester 1919/1920 - GA 58). Translated by Scott M. Campbell. London: Bloomsbury Academic, 2013.

. "The language of Peter Hebel". In: SALLIS, J. (org.) The Heidegger reader. Translated by Jerome Veith. Bloomington \& Indianopolis: Indiana University Press, 2009, p. 295-297.

"The origin of the work of art" (GA 5). In: Poetry, language, thought. Translated by Albert Hofstadter. New York: Harper \& Row, 1971, p. 15-86.

. The phenomenology of religious life (GA 60). Translated by Matthias Fritsch and Jennifer Anna Gosetti-Ferencei. Bloomington: Indiana University Press, 2004.

"The principle of identity". In: SALLIS, J. (org.) The Heidegger reader. Translated by Jerome Veith. Bloomington \& Indianopolis: Indiana University Press, 2009, p. 284-294. 
."The provenance of art and the destination of thought". In: Journal of the British Society for Phenomenology. Translated by Dimitrios Latsis, reviewed and amended by Ullrich Haase. Vol. 44, No. 2, May 2013, p. 119-128.

"The thing" (GA 7). Poetry, language, thought. Translated by Albert Hofstadter. New York: Harper \& Row, 1971, p.161184.

"Über die Sixtine". In: Aus der Erfahrung des Denkens - 1910-1976. (GA 13). Frankfurt am Main: Vittorio Klostermann, 1983, p. 119-121.

. What is a thing? (GA 41). Translated by W. B. Barton, Jr. and Vera Deutsch. Chicago: Henry Regnery Company, 1967.

. What is called thinking? (GA 8). Translated by Fred D. Wieck and J. Glenn Gray. New York: Harper \& Row, 1968.

HELFER, M. The retreat of Representation: the concept of Darstellung in German critical discourse. New York: New York Press, 1996.

HENNING, A. Die Sixtinische Madonna: Raffaels Kultbild wird 500. München: Prestel, 2012.

HERÁCLITO. "Fragmentos". In: ANAXIMANDRO; PARMENIDES; HERACLITO. Os pensadores originários: Anaximandro, Parmenides, Heraclito. Text of and translation by Emmanuel Carneiro Leão e Sergio Wrublewski. Petropolis, RJ: Vozes, 1991.

KEENAN, D. The question of sacrifice. Bloomington and Indianapolis: Indiana University Press, 2005.

KEMPIS, T. The Imitation of Christ. Translated by ?. General Editor: Rosalie De Rosset. Edited by Paul M. Bechtel [1980]. Chicago: Moody Publishers, 2007.

. De Imitatione Christi. ?:?,?. [livro eletrônico].

KIRK, G. S. \& RAVEN, J. E. The presocratic Philosophers: a critical history with a selection of texts. London \& New York: Cambridge University Press, 1977.

KLUGE, F. An Etymological Dictionary of the German Language. Translated by John Francis Davis. London: George Bell \& Sons; New York: Macmillan \& Co., 1891. 
LACOUE-LABARTHE, P. "A vera semelhança". In: Mímesis e expressão. Orgs. Rodrigo Duarte e Virginia Figueiredo. Belo Horizonte: Ed. UFMG, 2001. p. 15-48.

Heidegger and the politics of poetry. Translated by Jeff Fort. Urbana and Chicago: University of Illinois Press, 2007.

La vraie semblance. Paris: Éditions Galilée,

2008. "Typographies". In: Mimesis des articulations.

France: Flammarion, 1975, p. 165-270.

Typography: Mimesis, Philosophy, Politics.

Cambridge, MA \& London, England: Havard University Press, 1989.

LADWEIN, M. (ed.) Raffaels Sixtinische Madonna: Literarische Zeugnisse aus zwei Jahrhunderten Gesammelt und erläutert von Michael Ladwein. Dornach: Pforte, 2004.

LAERKE, M. "Deleuzian 'becomings and leibnizian transubstantiation". In: Pli 12. 2001, p. 104-117.

LA FARGE, J. Sistine Madonna (after Raphael). 1890-1891. Stained glass. $80 \times 32$ inches. Our Lady of Mercy Chapel, Newport. Available at http://library.bc.edu/lafargeglass/exhibits/show/descriptions/st-john/ourlady-of-mercy in 10/14/2017.

LAMMI, W. Gadamer and the question of the divine. London \& New York: Cotinuum, 2008.

MA, L. Heidegger on East-West dialogue: anticipating the event. New York \& London: Routledge, 2008.

MALY, K. "The transformation of "logic in Heraclitus". In: MALY, K. \& EMAD, P. Heidegger on Heraclitus: a new reading. Lewiston \& Queenston: The Edwin Mellen Press, 1986, p. 89-102.

\& DAVIS, S. "Reading Heidegger reading Heraclitus-Fragment 112". In: MALY, K. \& EMAD, P. Heidegger on Heraclitus: a new reading. Lewiston \& Queenston: The Edwin Mellen Press, 1986, p. 135-154.

MARION, J. God without being: hors texte. Translated by Thomas A. Carlson. Chicago \& London: The Chicago University Press, 1991.

- "La double idolâtrie - Remarques sur la difference ontologique et la pensé de Dieu". In: KEARNEY, R. \& O'LEARY, J. Heidegger et la question de Dieu. Paris: Bernard GRASSET, 1990, p. 46-74. 
The idol and the distance. Translated by Thomas A. Carlson. New York, Fordham University Press, 2001.

MARTIS, J. Philippe Lacoue-Labarthe: Representation and the loss of the subject. USA: Fordham University Press, 2005.

MCMANUS, D. Heidegger and the measure of truth: themes from his Early Philosophy. Oxford: Oxford University Press, 2012.

MCNEILL, W. The glance of the eye: Heidegger, Aristotle, and the Ends of Theory. New York: State University of New York Press, 1999.

MERLEAU-PONTY, M. "Eye and mind". In: The Merleau-Ponty Aesthetics Reader: Philosophy and Painting. Michael B. Smith, translation editor. Evanston, Illinois, Northwestern University Press, 1933, p. 121-162.

"Le doute de Cézanne". Sens et non-sens. Paris: Les Éditions Nage, 1966, p. 15-33.

Sense and non-sense. Translated by Hubert $L$. Dreyfus \& Patricia A. Dreyfus. Illinois: Northwestern University Press, 1964.

MICHELAZZO, J. Do um como princípio ao dois como unidade: Heidegger e a reconstrução ontológica do real. São Paulo: Annablume, 2010.

MICHELL, A. "Translator's Foreword". In: Bremen and Freiburg Lectures: insight into that which is and basic principles. Translated by Andrew J. Mitchell. Bloomington \& Indianapolis: Indiana University Press, 2012, p. vii-xvi.

MUCHAIL, S. "O movimento circular do pensamento heideggeriano". In: Debates Sociais. Ano. XXIV. $\mathrm{n}^{\circ}$ 47. Rio de Janeiro: Centro Brasileiro de Cooperação e Intercâmbio de Serviços Sociais - CBCISS, 1988. p. ?.

MUGERAUER, R. Heidegger and Homecoming: The Leitmotif in the Later Writings. Toronto; Buffalo; London: University of Toronto Press, 2008.

MUJICA, H. La palabra inicial: la mitología del poeta en la obra de Heidegger. Madrid: Editorial Trotta, 1995.

NANCY, J. Le regard du portrait. Paris: Éditions Galilée, 2000.

O'LEARY, J. S. "Topologie de l'être et topographie de la révélation". In: KEARNEY, R. \& O'LEARY, J. Heidegger et la question de Dieu. Paris: Bernard GRASSET, 1990, p. 194-237. 
OLWIG, K. "Representation and alienation in the political land-scape". In: Cultural geographies. Vol. 12 (1). SAGE Publications: 2005, p. 19-40.

PAYOT, D. La statue de Heidegger: art, vérité, souveraineté. Paris: Circé, 1998.

PERSEUS DIGITAL LIBRARY. Available at <http://www.perseus.tufts .edu/>. Access in 10/18/2017.

PIACENZA MUSEl. Available at <http://www.piacenzamusei.com/i.php? $\mathrm{i}=0043 \&$ img=imageg03\&did=didag03. Access in 10/18/2017.

PLATO. Plato in Twelve Volumes. Vol. 7. Translated by R. G. Bury. Cambridge, MA: Harvard University Press; London: William Heinemann Ltd, 1966. Press, 1903.

Platonis Opera. Editor: John Burnet. London: Oxford University . "Statesman". In: The Being of the beautiful: Plato's Theaetetus, Sophist, and Statesman. Translated by Seth Bernadete. University of Chicago Press, Chicago: 2006.

The Dialogues of Plato. Seventh Letter. Translated by J. Harward. Chicago; London: Encyclopaedia Britannica Inc., 1952.

PRENDERGAST, C. The triangle of representation. New York: Columbia University Press, 2000.

PRIER, R. A. Thauma idesthai: phenomenology of sight and appearance in archaic Greek. Florida: University Presses of Florida, 1989.

PUTSCHER, M. Raphaels Sixtinische Madonna: das Werk und seine Wirkung. Tübingen:Hopfer-Verlag, 1955.

RADLOFF, B. "Preliminary notes on divine images in the light of beinghistorical thinking". In: SCHALOW, F. (ed.) Heidegger, translation, and the task of thinking: essays in honor of Parvis Emad. New York: Springer, 2011, p. 145-171.

RAPHAEL (SANZIO). School of Athens. 1509-1511. Fresco. 200 in $\times 300$ in $(500 \mathrm{~cm} \times 770 \mathrm{~cm})$. Apostolic Palace, Vatican City. Available at https://en.wikipedia.org/wiki/The_School_of_Athens\#/media/File:Sanzio_0 1.jpg in 10/18/2017.

The Sistine Madonna. 1512/13. Oil on canvas. 265 cm x 196 cm (104 in x 77 in) Gemäldegalerie Alte Meister, Dresden. 
REIS, R. "Verdade e sacrifício na intencionalidade social". In: O que nos faz pensar. No. 34. Março 2014, p. 145-170.

RICHARDSON, W. Heidegger: through phenomenology to thought. Netherlands: The Hague, 1974.

RISSER, J. Hermeneutics and the voice of the other: re-reading Gadamer's Philosophical Hermeneutics. New York: State Universiy of New York Press, 1997.

RODIN, A. The Cathedral. 1908. Stone. H. $64 \mathrm{~cm} \times$ W. $29,5 \mathrm{~cm} \times$ D. 31,8 cm. Musée Rodin.

1921.

. Les Cathédrales de France. Paris: Librairie Armand Colin,

ROSS, A. The Aesthetic Paths of Philosophy: Presentation in Kant, Heidegger, Lacoue-Labarthe, and Nancy. Stanford: Stanford University Press, 2007.

RUSSMANN, E. Eternal Egypt: Masterworks of Ancient Art from the British Museum. California: University of California Press, 2001.

SALLIS, J. Being and Logos: reading the platonic dialogues. Indiana: Indiana University Press, 1996.

. Double truth. New York: State University of New York, 1995.

. Echoes: after Heidegger. Indiana: Indiana University Press, 1990.

. "Effacements of form". In: Frontiers of Philosophy in China. Vol 8. Issue 4. 2013, p. 641-654.

Force of imagination: the sense of the elemental. Indiana: Indiana University Press, 2000.

The logic of imagination: the expanse of the elemental. Indiana: Indiana University Press, 2012.

Transfigurements: on the true sense of art. Chicago \& London: The Chicago University Press, 2008.

On the verge of philosophy. Chicago: The university of Chicago Press, 2008.

SARAMAGO, L. A Topologia do Ser: lugar, espaço e linguagem no pensamento de Martin Heidegger. Rio de Janeiro: Ed. PUC-Rio; São Paulo: Edições Loyola, 2008. 
. "Espaço e obra de arte nos pensamentos de Heidegger e

Gadamer". In: ArteFilosofia. N. 1. Ouro Preto: Julho de 2006, p. 76-93.

SCHAPIRO, G. " 'Double-Coding the Sistine Madonna". In: Archaeologies of vision: Foulcault and Nietzsche on Seeing and Saying. Chiacago \& London: The University of Chicago Press: 2003, p. 106, 112.

SCHUBACK, M. "The fiction of the image". In: True Lies Worldwide: Fictionality in Global Contexts. Eds. Anders Cullhed, Lena Rydholm. Berlin: De Gruyter, 2014, p. 67-82.

SEEL, M. Aesthetics of appearing. Translated by John Farrell. California: Stanford University Press, 2005.

SMITH, W.; WAYTE, W.; MARINDIN, G. E. A Dictionary of Greek and Roman Antiquities. London: John Murray, 1890.

TONNER, P. Heidegger, Metaphysics and the univocity of being. New York: Continuum International Publishing Group, 2010.

UNKNOWN (artist). "Weighing of the heart", detail from the Book of the Dead. c. 1275 B.C. Photographed by the British Museum. 3,364 × 1,732 pixels. British Museum, London. Available at https://en.wikipedia.org/wiki/ Maat\#/media/File:BD_Weighing_of_the_Heart.jpg in 10/18/2017.

VASILIU, A. Du diaphane: image, milieu, lumière dans la pensée antique et médiévale. Paris: Vrin, 1997.

Paris: PUF, 2010.

Eikôn: L'image dans le discours des trois Cappadociens.

"Eikôn Praeter Imaginem: Notes sur le vocabulaire de l'image à la fin de l'Antiquité". In: De Zénon d'Elée à Poincaré: recueil d'études em hommage à Roshdi Rashed. Louvain: Peeters, 2004, p. 779817.

"Le mythe fondateur et l'image du monde (narration et anarrativité d'une fondation)". In: SCHWEIDLER, W. (Org.). Welbild Bildwelt: Ergebnisse und Beiträge des Internationalen Symposiums der Hermann und Marianne Straniak Stiftung Weingarten 2005. Germany: Academia Verlag, 2007, p. 347-379.

"L'icône invisible ou le seul liturgique du regard". In: Revue Roumaine d'histoire de l'art. Serie Beaux-arts. t. 36, Bucarest: Académie Roumaine, sept.2003, p. 19-30.

VERNANT, J. “Image, Imaginaire, Imagination". In: Entre mythe et politique. Paris: Éditions du Seuil, 1996. p. 359-377. 
. "Splendeur divine". In: Entre mythe et politique. Paris: Éditions du Seuil, 1996. p. 518-524.

WATT, J. The World of Khubilai Khan: Chinese Art in the Yuan Dynasty. New Haven and London: Yale University Press, 2010.

WIKIPEDIA. Chiesa di San Sisto. Available at <https://it.wikipedia. org/wiki/Chiesa_di_San_Sisto_(Piacenza)>. Access in 10/18/2017.

WITTGENSTEIN, L. "Culture and value". In: Culture and Value: a selection from the posthumous remains. Ed. G. M. von Wright. Translated by Peter Winch. USA: Blackwell Publishing, 1998.

Luz e sombras: uma experiência (onírica) noturna e um fragmento de carta. Translated by. Edgar da Rocha Marques. São Paulo: Martins Fontes, 2012

WEFELMEYER, F. (ed.) "Raphael's Sistine Madonna: an Icon of German Imagination from Herder to Heidegger". In: MORRISON, J \& KROBB, F. Text into image: image into text. Proceedings of the Interdisciplinary Bicentenary Conference Held at St. Patrick's College Maynooth (The National University of Ireland) in September 1995. Amsterdam, Atlanta: Editions Rodopi, 1997, p. 105-118.

YARNALL, J. "John La Farge's Windows for the Caldwell Sisters of Newport". In: Rhode Island History. Volume 64, no. 2 (Summer 2006), Rhode Island: Rhode Island Historical Society, p. 31-47.

ZARADER, M. "The mirror with the triple reflection". In: MACANN, C. (ed.): Martin Heidegger: Critical Assessments. Vol. II. London and New-York: Routledge ed., 1992, p. 17-36.

. Les paroles de l'origine. Paris: Vrin, 1986.

The Unthought Debt: Heidegger and the Hebraic Heritage.

Translated by Bettina Bergo. Stanford, CA: Stanford University Press, 2006.

ZIEGLER, S. "Matter Schein: Zu Heideggers Phänomenologie des Unscheinbaren". In: Heidegger Studies, Heidegger Studien, Études heideggeriennes. Vol 30. Berlin: Duncker \& Humblot: 2014 , p. 97-108. 
The following pictures are a contextualization of parts of the dissertation.

Figure 6 shows $^{578}$ the sumptuous Baroque frame by Giovanni Sete the Sistine received in 1697/98. It was not its original frame. It is worth noticing the two angels above the painting crowning the Madonna.

The bezel with the two angels, which is above the copy in the altar frame, seems to be of a Mannerist origin, and may have been attached to Raphael's painting in the rebuilding of the church in 1544. If also then the upper picture strip of the Sistine Madonna had already been thrown back, so that the curtain rod was no longer visible, or if it was only with the novelties by Giuseppe Grattoni 1599 or rather by Sete 1697/98, is not assured. When the picture arrived in Dresden in 1754, the upper canvas area was turned over ${ }^{579}$.

Figure 7 is La Farge's stained glass ${ }^{580}$ inspired by the Sistine Madonna.

Figure 8 is a zoom in a detail of the reconstruction on how the church probably looked like before the reformation.

Figures 9 and 10 show the main nave of Piacenza's Church, San Sisto. Picture 9 shows a reconstruction of how the church probably looked like before the reformation. Picture 10 shows it after the reformation ${ }^{581}$.

\footnotetext{
578 The following pictures $(6,9,10$ and 14) were taken from Marielen Putscher's thesis, Raphaels Sixtinische Madonna.

${ }^{579}$ HENNING, M. p. 29. Original: "Die Lünette mit den beiden Engeln, die sich über der Kopie in dem Altarrahmen befindet, scheint manieristischen Ursprungs zu sein und ist eventuell schon beim Umbau der Kirche 1544 über Raffaels Gemälde angebracht worden. Ob auch damals bereits der obere Bildstreifen der Sixtinischen Madonna zurückgeschlagen wurden, sodas die Vorhannfstange nicht mehr zu sehen war, oder erst mit den Neurahmungen durch Giuseppe Grattoni 1599 beziehungsweise Sete 1697/98, ist nicht gesichert".

${ }^{580}$ The picture was available at <http://library.bc.edu/lafargeglass/exhibits/show/descriptions/stjohn/our-lady-of-mercy> in 10/18/2017.

581 The picture was available at <https://www.comune.piacenza.it/welcome/the-city/what-tosee/church/san-sisto-church> in 10/18/2017.
} 
Figure 11 is Raphael's School of Athens. Putscher calls attention to the resemblance between the architecture of San Sisto Church in Piacenza and the one of this fresco. It seems to be unlikely that the fresco was inspired in the Piacenza church. Nevertheless, it might have been an indirect inspiration. Putscher indicates the reference of Bramante's choir at the Holy Mary of Grace Church in Milan as a possible connection ${ }^{582}$.

Figure 12 shows the main nave of Holy Mary of Grace Church ${ }^{\mathbf{5 8 3}}$.

Figures 13 and 14 are views from above, floor plans, from the altar and the side aisles of San Sisto Church $^{584}$.

Figure 15 shows the whole handscroll of Zhu Derun's Primordial Chaos.

Figure 16 show a wider detail of the "Weighing of the heart" from the Book of the Dead ${ }^{585}$.

\footnotetext{
582 See PUTSCHER, M. Raphaels Sixtinische Madonna, p. 177.

583 The picture was available at <http://www.aviewoncities.com/img/milan/kveit3428s.jpg> in 10/18/2017.

${ }^{584}$ Picture 13 was available at <https://it.wikipedia.org/wiki/Chiesa_di_San_Sisto_(Piacenza) > in $10 / 18 / 2017$.

585 Photographed by the British Museum.
} 


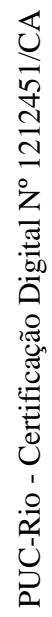

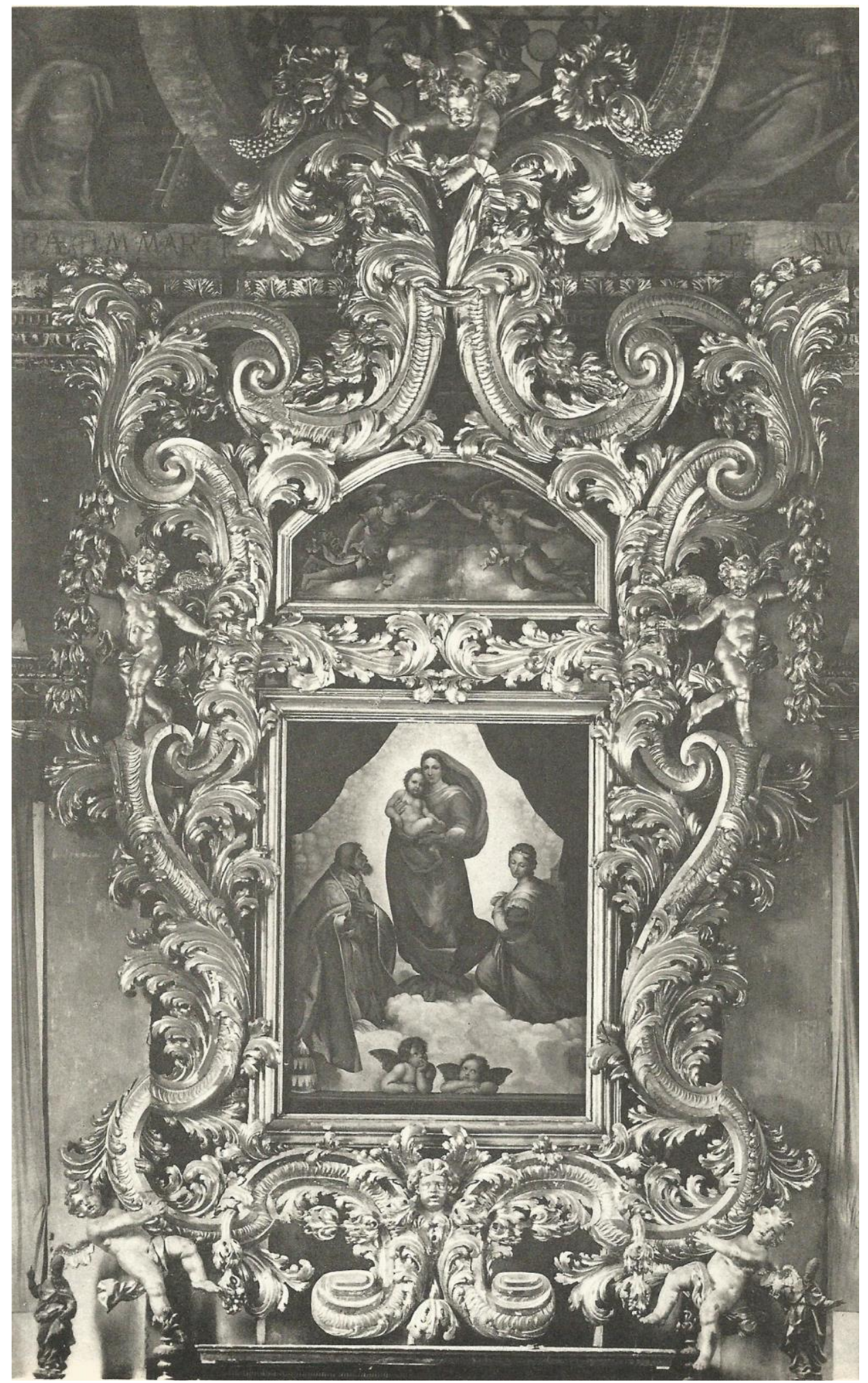

Figure 6 


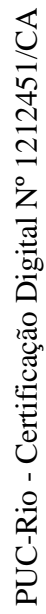

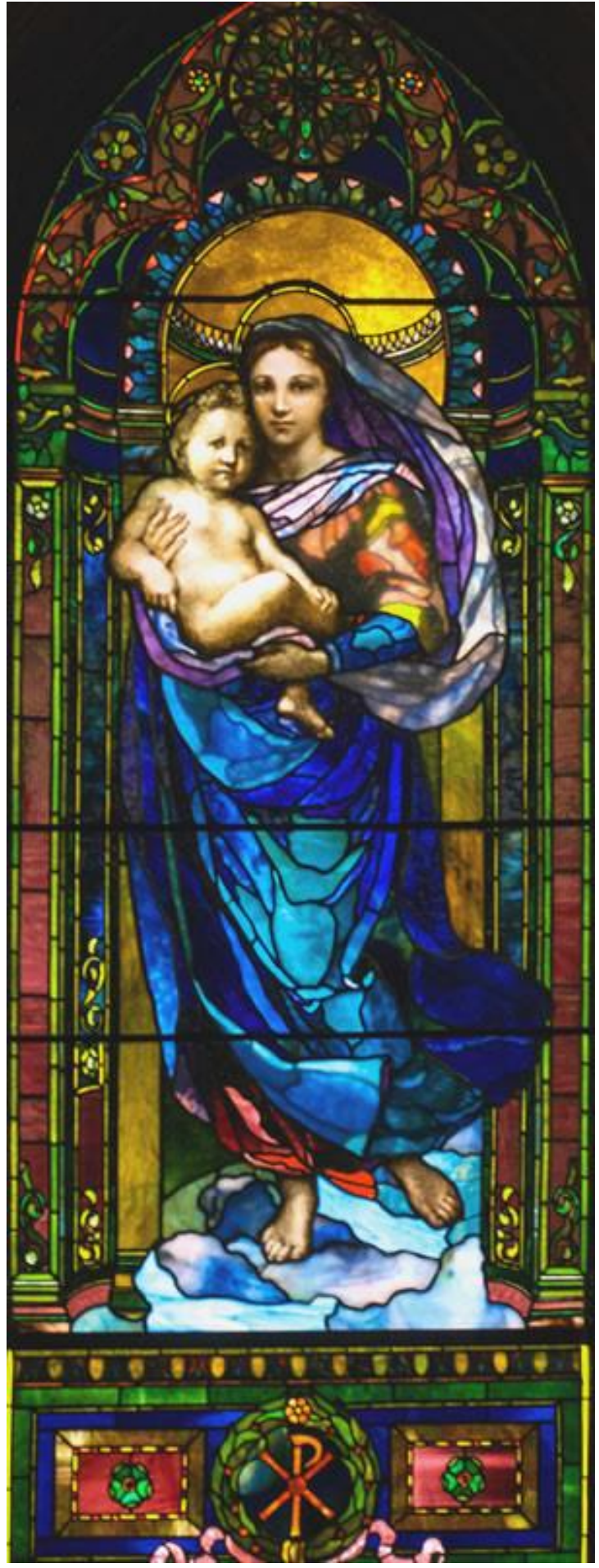

Figure 7

The Sistine Madonna (after Raphael) - La Farge - 1890/1891

Our Lady Chapel, Newport 

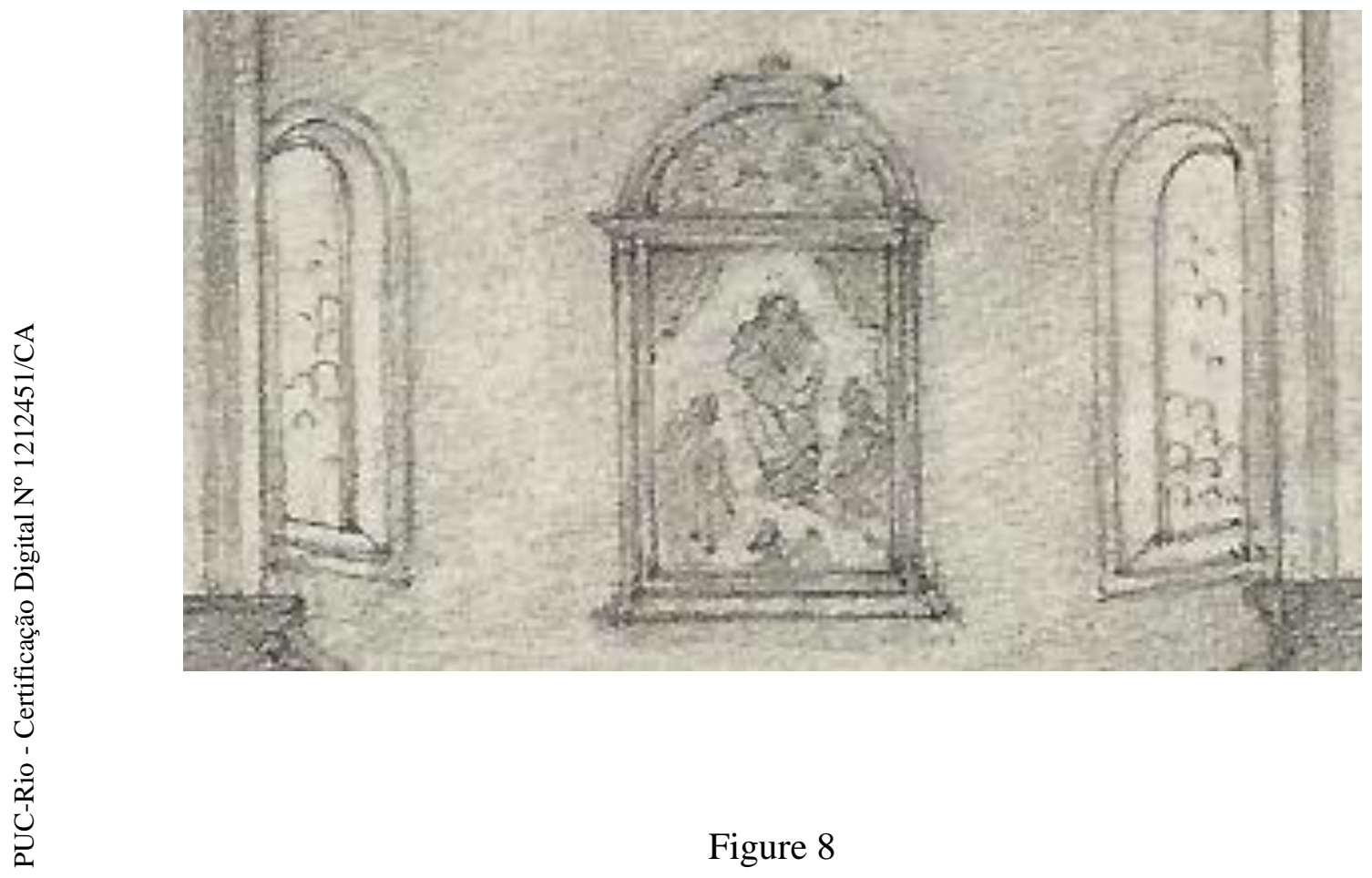

Figure 8 


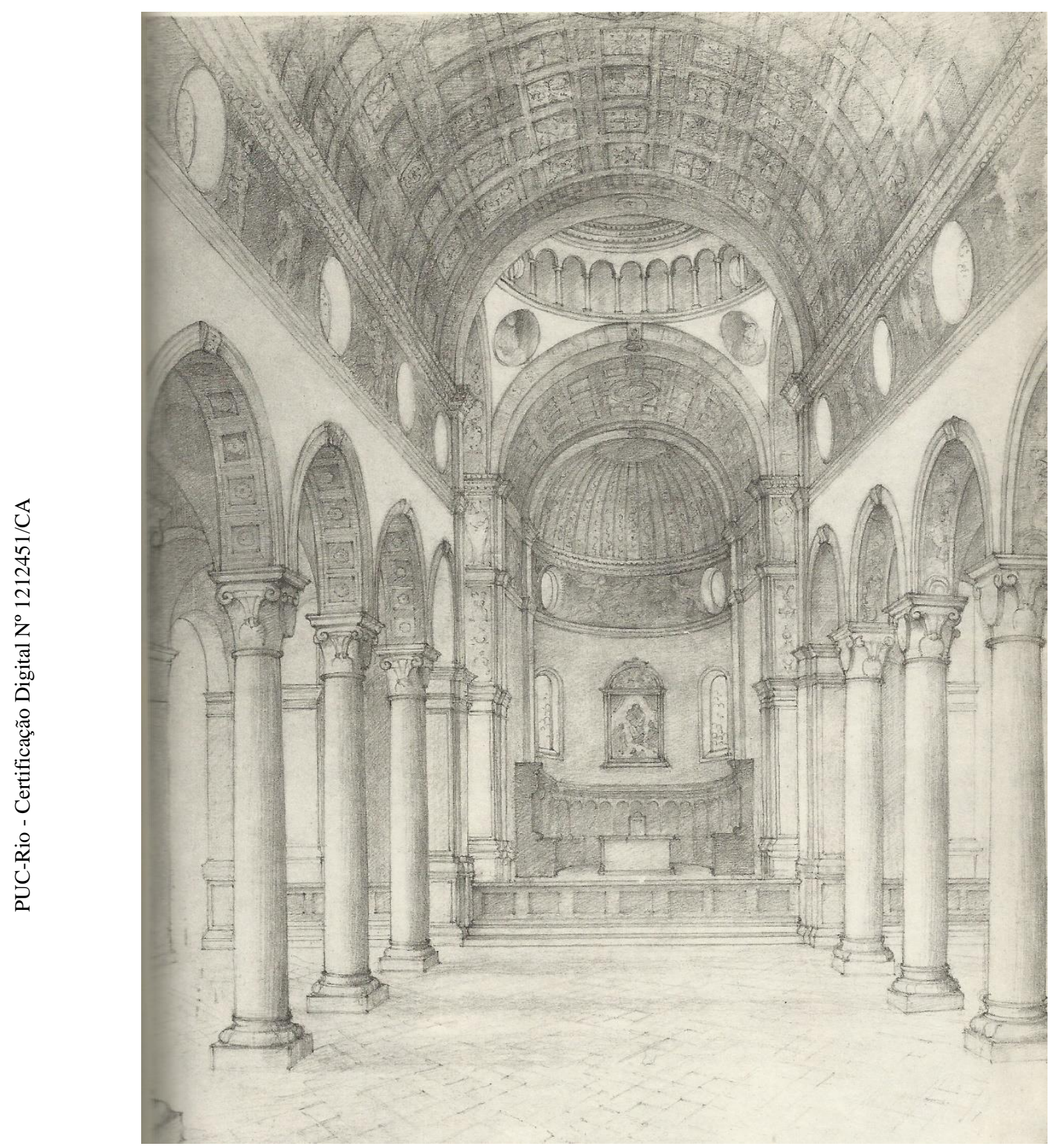

Figure 9 


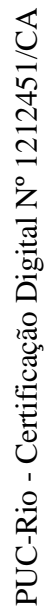

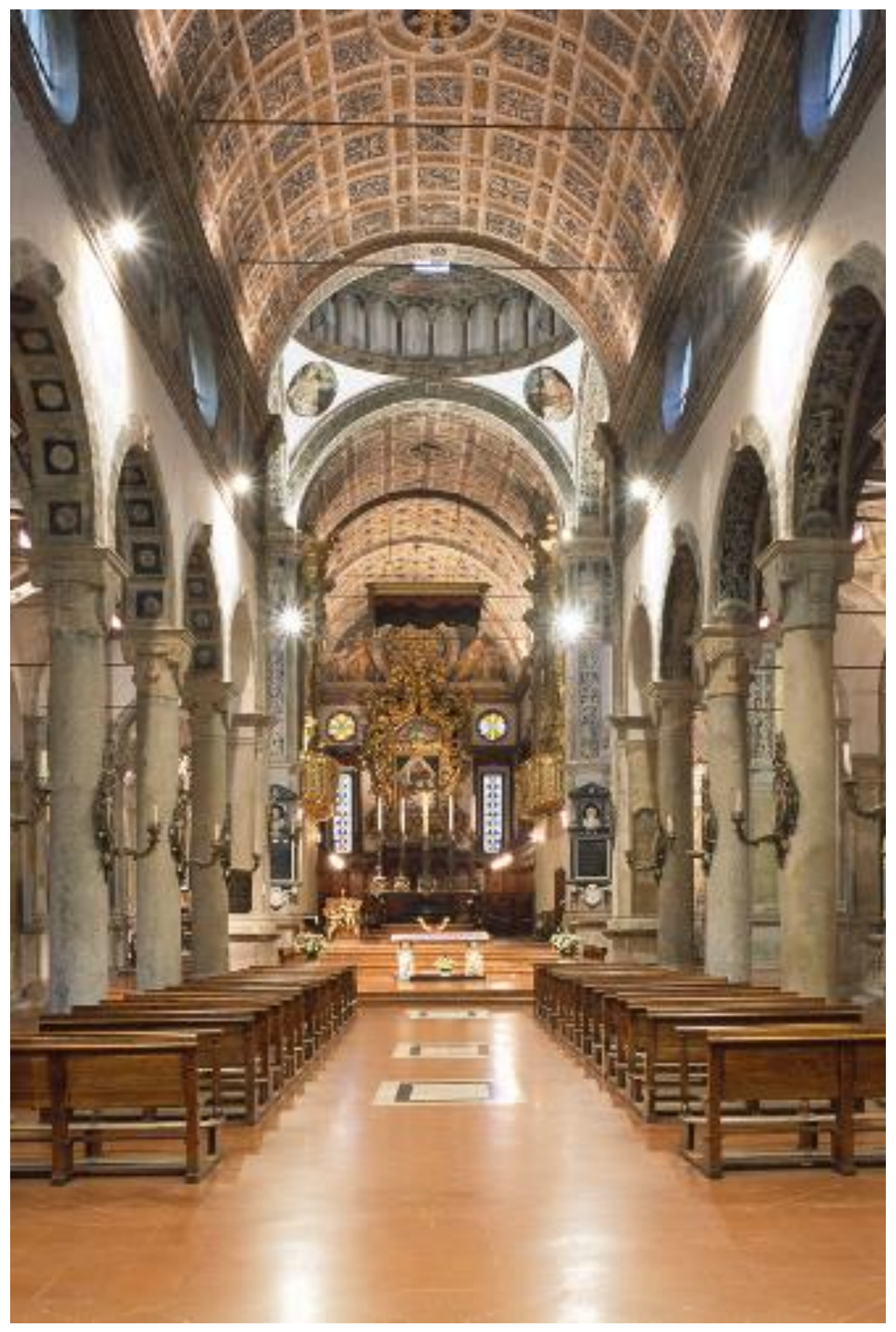

Picture 10

Main Nave of San Sisto Church, Piacenza 


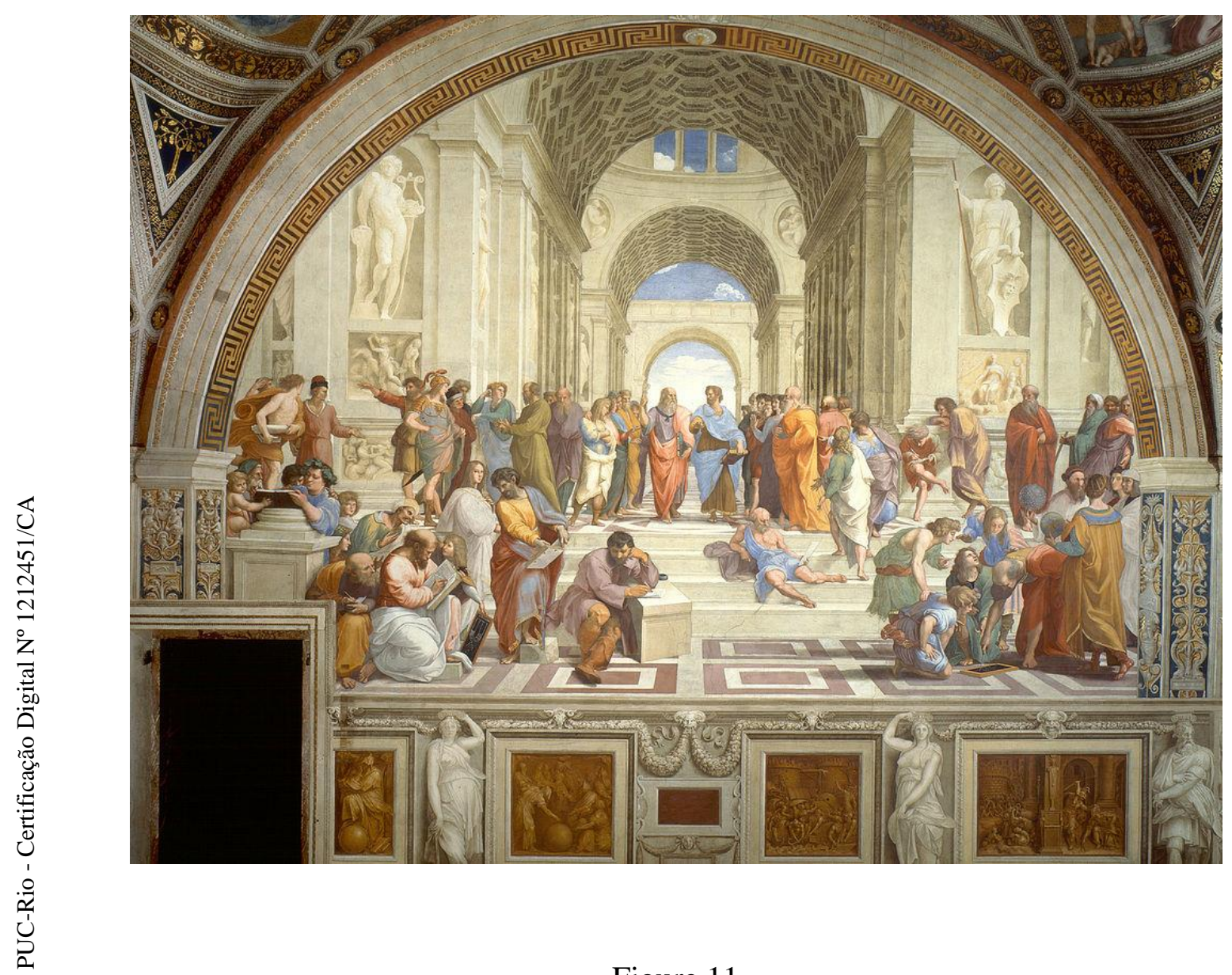

Figure 11

School of Athens - Raphael - 1509-1511

Apostolic Palace, Vatican City 


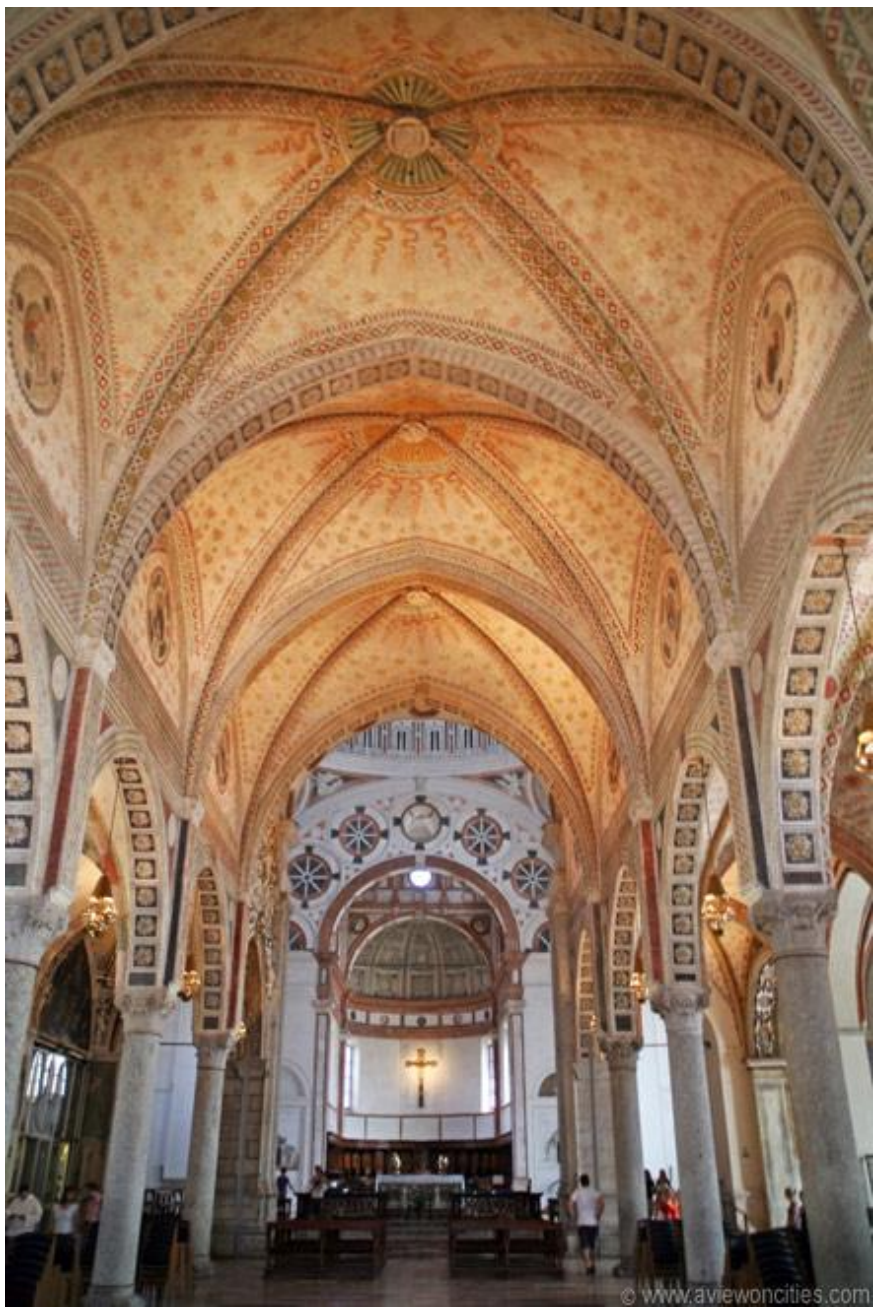

Figure 12

Main nave

Holy Mary of Grace Church, Milan 


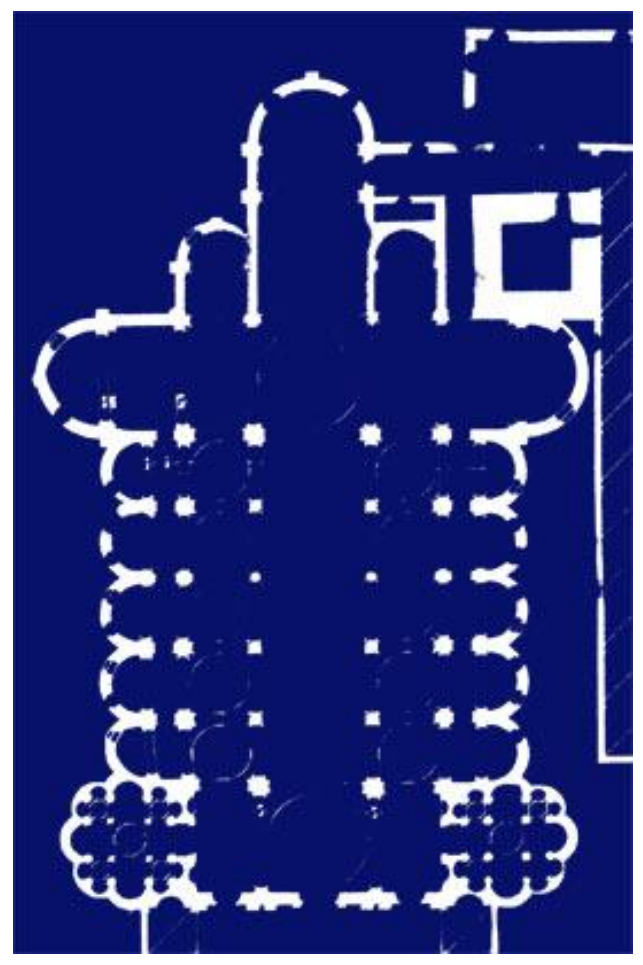

Figure 13

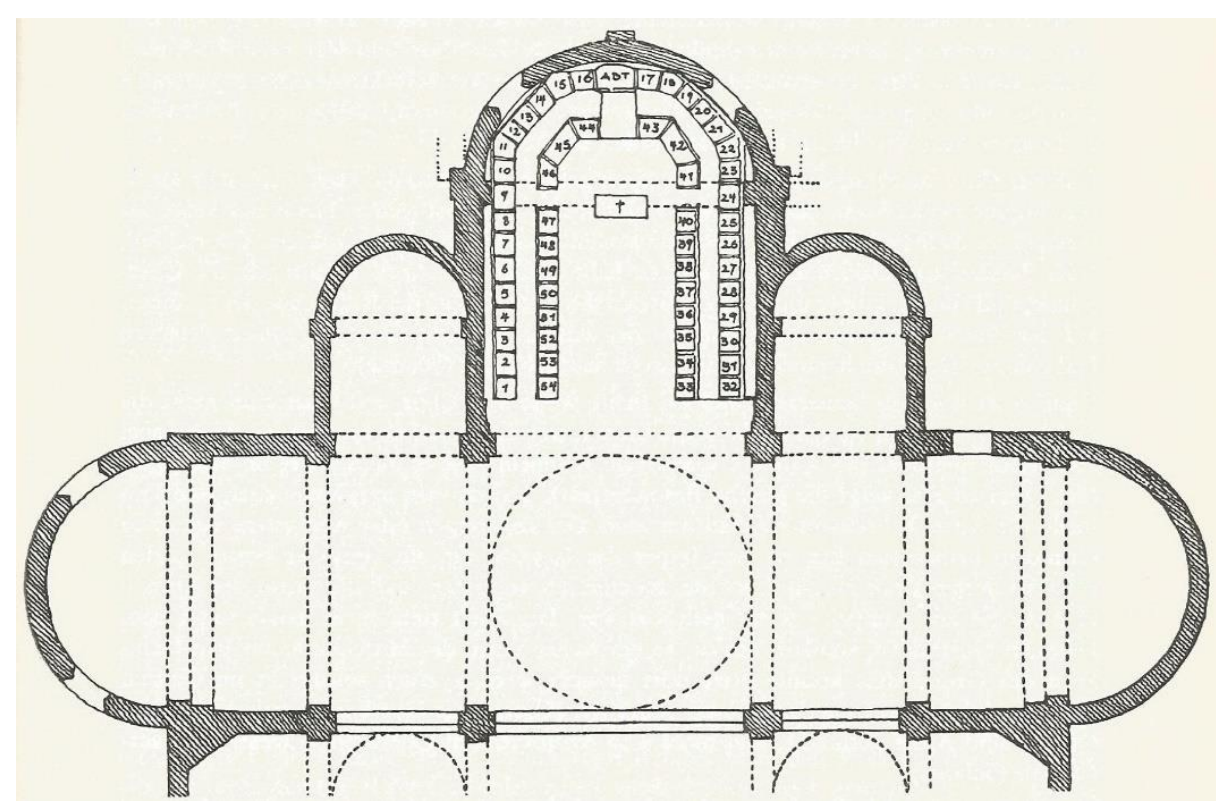

Figure 14 


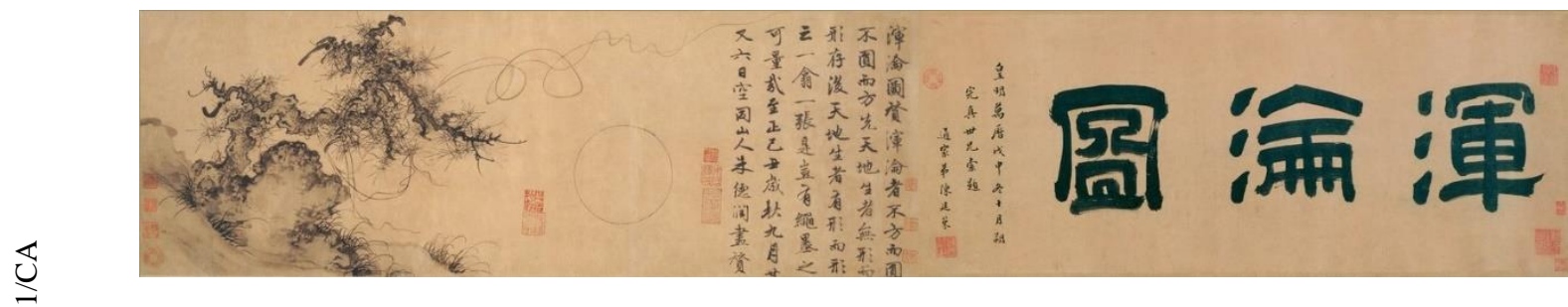

Figure 15

Primordial Chaos - Zhu Derun - 1349

Shanghai Museum, China 


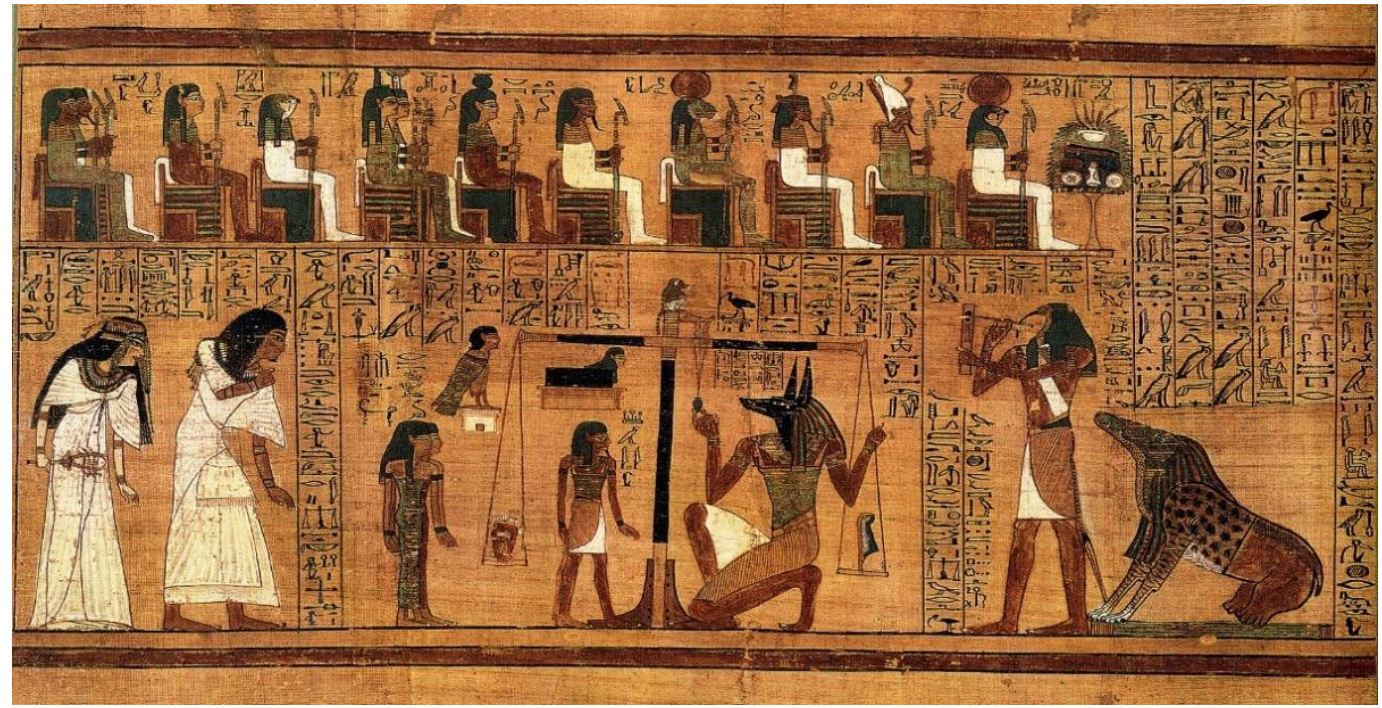

Figure 16

"Weighing of the heart", detail from the Book of the Dead

Original artist unknown. c. 1275 B.C.

British Museum, London 